JOÃO MALUF JÚNIOR

METÓDICA ESTRUTURANTE E ORDEM ECONÔMICA: ANÁLISE DE ARGUMENTOS DA JURISPRUDÊNCIA DO STF.

DISSERTAÇÃO DE MESTRADO

ORIENTADOR: PROF. DR. JOSÉ MARIA ARRUDA DE ANDRADE

FACULDADE DE DIREITO

UNIVERSIDADE DE SÃO PAULO

SÃO PAULO 
JOÃO MALUF JÚNIOR

\section{METÓDICA ESTRUTURANTE E ORDEM ECONÔMICA: ANÁLISE DE ARGUMENTOS DA JURISPRUDÊNCIA DO STF.}

DISSERTAÇÃO DE MESTRADO

ORIENTADOR: PROF. DR. JOSÉ MARIA ARRUDA DE ANDRADE

Dissertação de Mestrado apresentada à banca examinadora da Faculdade de Direito da Universidade de São Paulo como exigência parcial à obtenção do título de Mestre em Direito na área de concentração de Direito Econômico, Financeiro e Tributário.

FACULDADE DE DIREITO

UNIVERSIDADE DE SÃO PAULO

SÃO PAULO

2013 
JOÃO MALUF JÚNIOR

METÓDICA ESTRUTURANTE E ORDEM ECONÔMICA: ANÁLISE DE ARGUMENTOS DA JURISPRUDÊNCIA DO STF.

SÃO PAULO 
À Érika e Constança, pelo incentivo...

Aos professores Tércio Sampaio Ferraz Jr., José Maria Arruda de Andrade e Samuel Rodrigues Barbosa, pela inspiração... 


\section{RESUMO}

A chamada hermenêutica tradicional tem se mostrado impotente desde a Constituição de Weimar em acompanhar e explicar a transformação por que passaram as Constituições no século XX. Por outro lado, a moderna metodologia de interpretação da Constituição ampliou demasiadamente a importância do fator político, empobrecendo a consistência jurídica da Constituição, conduzindo a sua concretização a um estado de crise. Porém, não é possível desprezar as novas metodologias, especialmente naqueles países onde a democracia está longe de resolver as questões sociais. A Metódica Estruturante de Friedrich Müller, inserindo-se no rol das novas metodologias, intenta superar a deficiência verificada nas modernas teorias, assim como nas teorias tradicionais. Desenvolveu-se ela com base na experiência constitucional alemã e tratou de inúmeros temas da teoria jurídica, aproveitando o presente trabalho apenas o núcleo metodológico principal dessa teoria, a sua 'metódica jurídica', que consiste precisamente em uma particular concepção de estrutura da norma, que se revela num processo de concreção normativa. Pretende-se realizar o estudo dessa metódica, aplicando-a às decisões proferidas pelo Supremo Tribunal Federal no âmbito da ordem econômica, de modo a verificar conclusivamente a conformidade ou não dessa teoria com o modo como os magistrados da Corte Suprema estruturam seus votos. Assim, o objeto de trabalho da análise é a argumentação jurídica e a pergunta que se fará é, por um lado, em que medida a metódica estruturante descreve a organização argumentativa das decisões do STF e, de outro lado, em que medida apresenta-se estruturada a argumentação jurídica das decisões do STF à luz da metódica. Ao final, conclui-se que as decisões proferidas pelo Supremo não adotam um padrão de organização que siga um modelo estruturado como aquele erigido pela Metódica Estruturante.

Palavras -chave: Ordem Econômica. Metódica Estruturante. Friedrich Müller. STF. Análise de Argumentos. Concreção Normativa. 


\begin{abstract}
Since the Weimar Constitution, the so called Traditional Hermeneutics has been incapable of dealing with the changes occurred in the XX century constitutions. On the other hand, the modern theories have excessively enlarged the boundaries of interpretation, leading to a critical situation in this sector. Friedrich Müller theory, in spite of being a modern theory, intends to overcome these mentioned deficiencies. It was developed within the German constitutional experience and only the main core of it, the "law methodic", will be important for the purposes of this work. Therefore, the objective of this work is to apply Müller's "law methodic" to the decisions taken by the Brazilian Supreme Court in the field of constitutional economic order. At the end, the work concluded that the Brazilian Supreme Court decisions, in the field of the constitutional economic order, do not comply with a structural model of decisions like the one developed by Friedrich Müller.
\end{abstract}

Keywords: Constitutional Economic Order. "Law Methodic". Friedrich Müller. Brazilian Supreme Court. Argumentation Analysis. Hermeneutics. 
I. A ORDEM ECONÔMICA COMO CAMPO DE ESTUDO 3

1.1. A Ordem Econômica na Constituição............................................................................

1.2. A Escolha do Campo de Estudo..............................................................................

II. A METÓDICA ESTRUTURANTE DE FRIEDRICH MÜLLER 7

2.1. A Teoria Estruturante do Direito de Friedrich Müller.................................................. 7

2.2. A Metódica Jurídica e o Trabalho Jurídico.................................................................. 11

2.3. Jogos de Linguagem e Pré-compreensão................................................................... 15

2.4. A Estrutura da Norma....................................................................................... 18

2.5. A Concreção Normativa........................................................................................... 22

2.6. A Hierarquia dos Elementos e a Estrutura Jurídica Limitativa....................................... $\quad 30$

2.7. Norma, Normatividade e Validade......................................................................... 32

2.8. Críticas ao Modelo e sua Compilação..........................................................................

2.8.1. Esboço de Uma Crítica.................................................................................... 34

2.8.2. Esforço de Compilação....................................................................................

III. ANÁLISE DE DECISÕES NO ÂMBITO DO STF 43

3.1. Contornos de Análise.......................................................................................... 43

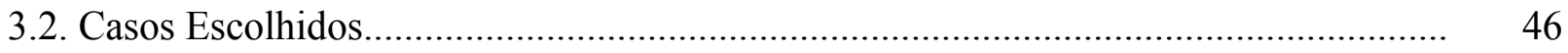

3.3. Aplicando a Metódica......................................................................................... 47

3.3.1. Caso dos Correios..................................................................................... 4

3.3.1.1. A Proteção Constitucional à Livre Iniciativa............................................. 48

3.3.1.2. A Noção de Serviço Público........................................................................ $\quad 49$

3.3.1.3. A Análise do Acórdão.............................................................................. 51

3.3.1.4. Considerações Finais Sobre o Caso......................................................... 59

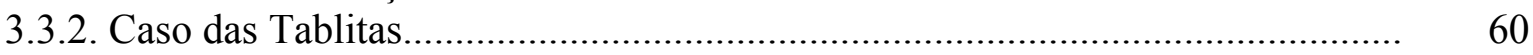

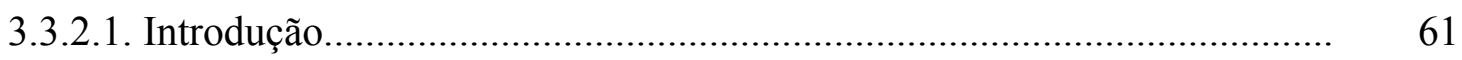

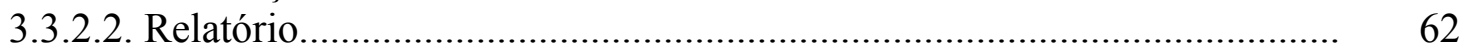

3.3.2.3. Os Elementos de Concreção no Caso........................................................... 63

3.3.2.4. Considerações Finais Sobre o Caso.......................................................... 74

3.3.3. Caso da Meia Entrada..................................................................................

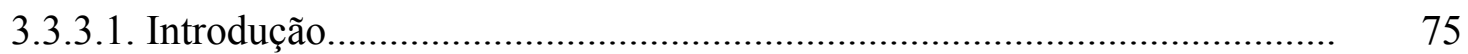

3.3.3.2. Os Elementos de Concreção no Caso......................................................... $\quad 76$

3.3.3.3. Considerações Finais Sobre o Caso........................................................... 78

3.3.4. Caso das Mensalidades Escolares................................................................... 79

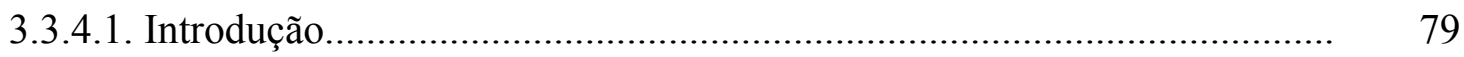

3.3.4.2. Os Elementos de Concreção no Caso........................................................... 81

3.3.4.3. Considerações Finais Sobre o Caso........................................................... 87

3.3.5. Caso das Farmácias........................................................................................ 89

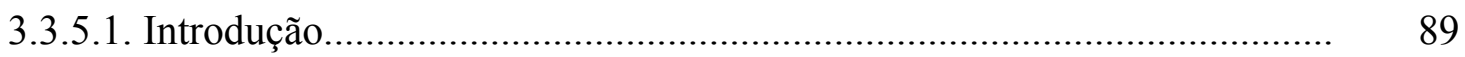

3.3.5.2. Os Elementos de Concreção no Caso......................................................... $\quad 90$

3.3.5.3. Considerações Finais Sobre o Caso........................................................... 91

3.3.6. Caso da Destilaria Alto Alegre............................................................................ 91

3.3.6.1. Introdução ............................................................................................. 
3.3.6.2. Os Elementos de Concreção no Caso......................................................... 93

3.3.6.3. Considerações Finais Sobre o Caso.......................................................... 94

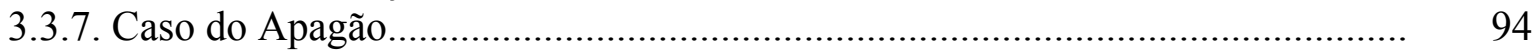

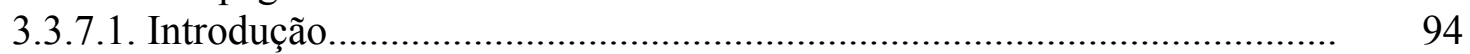

3.3.7.2. Os Elementos de Concreção no Caso...................................................... 96

3.3.7.3. Considerações Finais Sobre o Caso....................................................... 99

$\begin{array}{ll}\text { CONSIDERAÇÕES FINAIS } & 100\end{array}$

$\begin{array}{ll}\text { BIBLIOGRAFIA } & 107\end{array}$ 


\section{LISTA DE TABELAS}

Tabela I: Dados pré-jurídicos do modelo.

Tabela II: Elementos Jurídicos do modelo.

Tabela III: Elenco de casos escolhidos

Tabela IV: Síntese de resultados. 


\section{LISTA DE ABREVIATURAS E SIGLAS}

$\begin{array}{ll}\text { ABRAED } & \text { - Associação Brasileira das Empresas de Distribuição } \\ \text { ADECON } & \text { - Ação Declaratória de Constitucionalidade } \\ \text { ADI } & \text { - Ação Direta de Inconstitucionalidade } \\ \text { ADPF } & \text { - Arguição de Descumprimento de Preceito Fundamental } \\ \text { CDB } & \text { - Certificado de Depósito Bancário } \\ \text { CF } & \text { - Constituição Federal } \\ \text { DF } & \text { - Distrito Federal } \\ \text { ECT } & \text { - Empresa Brasileira de Correios e Telégrafos } \\ \text { ES } & \text { - Estado do Espírito Santo } \\ \text { FGV } & \text { - Fundação Getúlio Vargas } \\ \text { IAA } & \text { - Instituto do Açúcar e Álcool } \\ \text { MG } & \text { - Estado de Minas Gerais } \\ \text { MP } & \text { - Medida Provisória } \\ \text { PE } & \text { - Estado do Pernambuco } \\ \text { RE } & \text { - Recurso Extraordinário } \\ \text { SP } & \text { - Estado de São Paulo } \\ \text { STF } & - \text { Supremo Tribunal Federal }\end{array}$




\section{INTRODUÇÃO}

O presente trabalho, a ser realizado no âmbito da produção de dissertação jurídica exigida para a obtenção do grau de Mestre em Direito na Faculdade de Direito da Universidade de São Paulo, objetiva a análise da estruturação argumentativa das decisões emanadas do órgão de proteção constitucional brasileiro, à luz de uma teoria estruturante como a erigida pelo eminente mestre alemão, Friedrich Müller, por ele denominada de Metódica Estruturante.

Pretende-se realizar o estudo da Metódica Estruturante de Müller, aplicando-a às decisões proferidas pelo Supremo Tribunal Federal no âmbito da ordem econômica, de modo a verificar conclusivamente a conformidade ou não dessa teoria com o modo como os magistrados da Corte Suprema estruturam seus votos.

Assim, preliminarmente, o objeto de trabalho da análise, noção que aprofundaremos posteriormente, é a argumentação jurídica e a pergunta que se fará é, por um lado, em que medida a metódica estruturante descreve a organização argumentativa das decisões do STF e, de outro lado, em que medida apresenta-se estruturada a argumentação jurídica das decisões do STF à luz da metódica.

Sabe-se que a chamada hermenêutica tradicional, em verdadeiro anacronismo, tem se mostrado impotente desde a Constituição de Weimar em acompanhar e explicar a transformação por que passaram as Constituições no século XX. ${ }^{1}$

Por outro lado, a moderna metodologia de interpretação da Constituição ampliou demasiadamente a importância do fator político, empobrecendo a consistência jurídica da Constituição, conduzindo a sua concretização a um estado de crise ${ }^{2}$. Porém, não é possível desprezar as novas metodologias, especialmente naqueles países onde a democracia está longe de resolver as questões sociais ${ }^{3}$.

A Metódica Estruturante, inserindo-se no rol das novas metodologias, intenta superar a deficiência verificada nas modernas teorias, assim como nas teorias tradicionais. Desenvolveu-se ela com base na experiência constitucional alemã e tratou de inúmeros temas da teoria jurídica, porém, o presente trabalho, em razão dos objetivos a que se propõe, aproveitará apenas o núcleo metodológico principal dessa teoria, a sua 'metódica jurídica',

\footnotetext{
${ }^{1}$ P. BONAVIDES, Curso de Direito Constitucional, 24. ed., São Paulo, Malheiros, 2009, p. 484.

${ }^{2}$ P. BONAVIDES, Curso..., op. cit., p. 484.

${ }^{3}$ P. BONAVIDES, Curso..., op. cit., p. 487.
} 
que consiste precisamente em uma particular concepção de estrutura da norma, que se revela num processo de concreção normativa.

Assim, no presente trabalho a Metódica Estruturante não será tomada como uma Teoria Hermenêutica, na inteireza significativa desse termo, mas tão somente, aproveitando apenas o seu núcleo metodológico, tomar-se-á como um modelo de estruturação de decisões, um referencial com base no qual se pode analisar o grau de organização de decisões.

O trabalho está dividido em três partes, a primeira busca definir o que vem a ser o termo 'ordem econômica', campo no qual se inserem as decisões a serem analisadas.

A segunda parte, por sua vez, apresenta o referencial teórico, o modelo de aferição, portanto, o núcleo principal da Metódica Estruturante.

A terceira e última parte, a mais substancial, sem perder a noção de que a teoria de Friedrich Müller fora construída com base em uma análise indutiva da jurisprudência alemã, busca analisar o comportamento de sua metódica em face da realidade jurisprudencial pátria, por meio do estudo de casos transcorridos no âmbito do STF.

Importante asseverar que não se deixa de reconhecer, no presente trabalho, certa limitação em decorrência de ter sido a teoria de Müller engendrada em realidade social distinta, porém, desde já, assume-se que qualquer desconformidade verificada pode, de fato, decorrer da genética estrangeira desse referencial teórico.

Assim, analogamente à construção dessa metódica, em uma análise ex post, partiremos de casos concretos já decididos e, ainda que com pretensões incipientes, analisaremos os votos proferidos nesses julgados para verificarmos a existência de um processo de concreção normativa, nos moldes da Metódica Estruturante, efetivamente levado a cabo pelos juízes, quando do trabalho jurídico.

Ao final, pretende-se concluir que a Metódica Estruturante constitui um modelo de estruturação pelo qual se organizam as decisões analisadas no âmbito da Corte constitucional brasileira. Caso contrário, concluir-se-á que as decisões proferidas pelo Supremo não adotam um padrão de organização que siga um modelo estruturado como aquele erigido pela Metódica Estruturante. 


\section{A ORDEM ECONÔMICA COMO CAMPO DE ESTUDO}

\subsection{A Ordem Econômica na Constituição}

Antes de prosseguirmos com o estudo do referencial teórico da Metódica Estruturante de Müller com vistas à análise de decisões sobre a temática da ordem econômica, torna-se imperioso escrever algumas linhas a respeito da concepção de ordem econômica adotada no presente trabalho.

É bem de se dizer que, enquanto a argumentação a ser extraída de cada voto dos Ministros do Supremo é o objeto do presente trabalho, a 'ordem econômica' é o substrato sobre o qual se encontra assentado esse objeto. Com isso, quer-se dizer que o objeto do presente trabalho não é a 'ordem econômica', porém é ela que desenha os contornos dentro dos quais se situa o objeto, a argumentação jurídica.

Assim, por um lado tem-se o referencial teórico da análise aqui proposta, a Metódica Estruturante, por outro, tem-se o substrato, o campo de estudo, a 'ordem econômica', do qual se retira o objeto de análise, a argumentação da jurisprudência do STF.

Dito isso, convém estabelecer, sem rodeios, a concepção de 'ordem econômica' adotada no presente trabalho, que, evidentemente, definirá o campo limite da análise, ou melhor, o campo em que se situam os casos a serem analisados.

Eros Grau define ‘ordem econômica' como sendo, não um conjunto de princípios jurídicos de conformação do processo econômico, noção de cujo equívoco penitenciou-se em sua obra A Ordem Econômica na Constituição de 1988, mas como sendo o conjunto de normas que define, institucionalmente, um determinado modo de produção econômica. ${ }^{4}$

Essa é a concepção com a qual se pode ler o termo 'ordem econômica' posto no título da presente dissertação, portanto, como um conjunto de normas, parcela da ordem jurídica, mundo do dever-ser.

Porém, antes de seguirmos com a descrição desse campo normativo, necessário que se esclareça o significado do termo 'ordem econômica' utilizado no art. 170, da Constituição Federal.

${ }^{4}$ GRAU, E. R., A Ordem Econômica na Constituição de 1988, 12. ed., rev. e atua., São Paulo, Malheiros, 2007, p. 72: “Com efeito, corrigindo o equívoco - pelo qual me penitencio - de tomar a ordem econômica como 'conjunto de princípios (apenas de princípios) jurídicos de conformação do processo econômico, desde uma visão macrojurídica...', no que indevida restrição do seu significado, a descrevo, agora, como o conjunto de normas que define, institucionalmente, um determinado modo de produção econômica. Assim, ordem econômica, parcela da ordem jurídica (mundo do dever-ser), não é senão o conjunto de normas que institucionaliza uma determinada ordem econômica (mundo do ser)." 
Com efeito, embora o referido termo esteja sendo citado em texto de artigo da própria Constituição, o art. 170, o que poderia levar ao engodo de entendê-lo no sentido correntemente normativo, como bem explica Eros Grau, aí o seu significado corresponde meramente ao modo de ser de uma determinada economia real, no caso a brasileira. ${ }^{5}$

"Art. 170 A ordem econômica, fundada na valorização do trabalho humano e na livre iniciativa, tem por fim assegurar a todos existência digna, conforme os ditames da justiça social, observados os seguintes principios".(g.n.)

Eros Grau nos fornece uma leitura do art. 170, nos seguintes termos: "as relações econômicas - ou a atividade econômica - deverão ser (estar) fundadas na valorização do trabalho humano e na livre iniciativa, tendo por fim (fim delas, relações econômicas ou atividade econômica) assegurar a todos existência digna, conforme os ditames da justiça social, observados os seguintes princípios..." ${ }^{6}$.

Nada obstante, o art. 170 e demais artigos no mesmo capítulo da Carta, além de outros da Constituição, apresentam preceitos que integram a ordem econômica como parcela da ordem jurídica, esta, por sua vez, como o sistema de princípios e regras jurídicas, portanto uma ordem normativa ${ }^{7}$. De fato, a ordem jurídica compreenderia, ao lado de uma ordem econômica, uma ordem pública, uma ordem privada e uma ordem social ${ }^{8}$.

Em síntese, com Eros Grau: “Assim, ordem econômica, parcela da ordem jurídica (mundo do dever ser), não é senão o conjunto normas que institucionaliza uma determinada ordem econômica (mundo do ser)." 9 .

De tudo o que foi dito, temos que o substrato que define os contornos do presente trabalho é a ordem econômica no sentido jurídico, portanto um campo normativo.

Embora esse campo normativo não venha a se exaurir no âmbito constitucional, este é o que mais nos interessa no presente trabalho uma vez que limitamos a análise à jurisprudência do Supremo Tribunal Federal, guardião da constituição e por onde tramitam,

\footnotetext{
${ }^{5}$ GRAU, E. R., A Ordem Econômica ..., op. cit., p. 68: "Neste art. 170, a expressão é usada não para conotar o sentido que supunha nele divisar (isto é, sentido normativo), mas sim para indicar o modo de ser da economia brasileira, a articulação do econômico, como fato, entre nós (isto é, "ordem econômica" como conjunto das relações econômicas)".

${ }^{6}$ GRAU, E. R., A Ordem Econômica ..., op. cit., p. 68.

${ }^{7}$ GRAU, E. R., A Ordem Econômica ..., op. cit., p. 68. “...embora nesta norma-objetivo, insculpida neste art. 170, a expressão tenha sido empregada para designar uma realidade do mundo do ser, prossegue a Constituição, nos preceitos seguintes, a dispor normas que estão integradas na parcela da ordem jurídica que se refere como ordem econômica (mundo do dever ser, portanto)".

${ }^{8}$ GRAU, E. R., A Ordem Econômica ..., op. cit., p. 60. "A ordem jurídica tomada como sistema de princípios e regras jurídicas compreenderia uma ordem pública, uma ordem privada, uma ordem econômica e uma ordem social.".

${ }^{9}$ GRAU, E. R., A Ordem Econômica ..., op. cit., p. 72.
} 
precipuamente, demandas constitucionais. Assim, no âmbito constitucional, esse campo normativo compõe-se de normas de ordem pública e de normas que instrumentam a intervenção do Estado na economia ${ }^{10}$.

Apenas exemplificativamente, as seguintes temáticas têm como locus de regulação normativa o campo da 'ordem econômica' como parcela da ordem jurídica: a livre iniciativa, a livre concorrência, a defesa do consumidor, a intervenção do Estado na economia e seus modos, a definição de atividade econômica em sentido lato e em sentido estrito, a definição de serviço público, a liberdade de exercício de atividade econômica, a repressão ao abuso do poder econômico, o Estado como agente normativo e regulador da atividade econômica etc.

Do exposto, inseridos na temática da 'ordem econômica', são esses, potencialmente, os temas a serem apreciados quando da análise a que aqui se pretende e, de outro lado, determinantes do critério de escolha dos casos a serem estudados.

\subsection{A Escolha do Campo de Estudo}

Assim, após definirmos os contornos do substrato de análise, a 'ordem econômica' como o conjunto de preceitos normativos, desde a Constituição Federal, que institui outra 'ordem econômica', no sentido de ordem do mundo real, das relações e atividades econômicas de determinado modo de produção em determinado lugar - o modo capitalista no Brasil, cumpre tecermos algumas palavras a respeito do critério de escolha desse substrato.

Primeiramente, os textos normativos não apresentam características que os diferenciem uns dos outros de modo a, necessariamente, implicar uma preferência, em razão dos objetivos aqui propostos, por este ou aquele determinado corpo de normas jurídicas. Assim, não há uma razão necessária para a escolha da 'ordem econômica' como substrato de análise.

Nada obstante, não se pode deixar de reconhecer que essas temáticas, referidas no subcapítulo anterior, derivadas do corpo de princípios e regras jurídicas que compõem a 'ordem econômica', como parcela da ordem jurídica, assumem, ou pelo menos deveriam assumir, num debate jurisprudencial, um caráter em grande medida conjuntural; isso, pela singela razão de que têm como função primordial a conformação de uma 'ordem econômica'

${ }^{10}$ GRAU, E. R., A Ordem Econômica ..., op. cit., p. 75: "De uma banda, a nova ordem econômica (mundo do dever ser), além de não se exaurir no nível constitucional - deixe-se isso bem vincado -, da antiga se distingue na medida em que, ao contrário do que ocorre em relação a esta, compreende não apenas, fundamentalmente, normas de ordem pública, mas também, e em profusão enorme, normas que instrumentam a intervenção do Estado na economia - normas de intervenção." 
das relações e atividades econômicas do mundo real, e, nesse sentido, dotadas de uma maior riqueza de elementos de ordem fática e axiológica, mas também de elementos da própria teoria econômica, que reclama para si um estatuto de cientificidade.

Em suma, o presente trabalho, tendo em vista a oportunidade, porque inserido nas linhas de pesquisa do Departamento de Direito Econômico desta Faculdade, de tratar com um campo que é potencialmente promissor para a análise aqui proposta, conforme defendido no parágrafo precedente, tem esse campo, a 'ordem econômica', como substrato sobre o qual serão analisados os argumentos da jurisprudência do Supremo. 


\section{A METÓDICA ESTRUTURANTE DE FRIEDRICH MÜLLER}

\subsection{A Teoria Estruturante do Direito de Friedrich Müller ${ }^{11}$}

A partir do presente subcapítulo será apresentada a 'metódica jurídica' concebida por Friedrich Müller, que, conforme já estabelecido na introdução deste trabalho, constituirá o fundamento metodológico adotado para a análise de argumentos da jurisprudência do Supremo Tribunal Federal, no campo da Ordem Econômica.

Pois bem, a concepção teórica desenvolvida por Friedrich Müller, designada de Teoria Estruturante do Direito ${ }^{12}$, desenvolveu-se com base na experiência constitucional alemã e tratou de inúmeros temas da teoria jurídica, de modo que o presente trabalho, de enfoque bastante limitado em face dos objetivos a que se propõe, aproveitará apenas o núcleo metodológico principal dessa teoria, obviamente de sua 'metódica ${ }^{13}$ jurídica', que consiste precisamente em uma particular concepção de estrutura da norma, que se revela num processo de concreção normativa.

De um modo geral, é de se dizer que a concepção hermenêutica desenvolvida por Müller tem o propósito, à semelhança de outros autores, como os juristas alemães Viehweg, Alexy, Häberle, Hesse e Hassemer, de trilhar um caminho intermediário entre a perspectiva subsuntiva e a casuística, que são os extremos verificados na hermenêutica constitucional. ${ }^{14}$

A perspectiva subsuntiva, ou silogística, entende que a norma geral constitui a

\footnotetext{
${ }^{11}$ Ex-Professor Catedrático de Direito Constitucional, Administrativo, Canônico e de Filosofia e de Teoria do Direito na Universidade de Heidelberg - Alemanha.

${ }^{12}$ A designação de 'Teoria Estruturante do Direito' foi aqui adotada por ser aquela comumente utilizada pela doutrina. Nada obstante, segundo O. JOUANJAN, De Hans Kelsen a Friedrich Müller - Método jurídico sob o paradigma pós-positivista, trad. port. de R. I. Jansen dos Santos, in O Novo Paradigma do Direito Introdução à teoria e metódica estruturantes do direito, São Paulo, Revista dos Tribunais, 2007, p. 247, a teoria de Müller é composta de uma dogmática jurídica, de uma metódica jurídica, de uma teoria do direito e de uma teoria constitucional.

13 O termo 'metódica' será adotado neste trabalho, em lugar de 'metodologia', em face de seu uso mais freqüente na doutrina e com base na explicação em notas do tradutor para língua portuguesa em F. MÜLLER, Direito, linguagem, violência, trad. port. de P. Naumann, in O Novo Paradigma do Direito - Introdução à teoria e metódica estruturantes do direito, São Paulo, Revista dos Tribunais, 2007, nota $\mathrm{n}^{\circ}$ 01, pp. 195196, conforme segue: “A solução terminológica aqui proposta visa conferir direito de cidadania ao substantivo 'metódica' no discurso científico de língua portuguesa, por ser ele mais pertinente do que a solução usual 'metodologia'. Não se deve esquecer que 'retórica', 'lógica', 'maiêutica', 'poética' e muitos outros termos são originalmente adjetivos. Ninguém pensa hoje em abrir mão dos substantivos derivados desses adjetivos. A introdução do substantivo 'metódica' no contexto da primeira tradução de um trabalho de Friedrich Muller se justifica também com vistas a uma futura tradução da sua 'Juristische Methodik' ('Metódica Jurídica')."

14 J. M. ADEODATO, Ética e retórica - para uma teoria da dogmática jurídica, São Paulo, Saraiva, 2002, p. 224.
} 
premissa maior, dentro da qual o caso concreto se coloca como premissa menor, possibilitando a decisão, esta equivalente à conclusão do silogismo. A visão casuística é menos confiante nas generalizações e parte do princípio de que a norma geral por si só não garante a racionalidade, a justiça ou qualquer outra forma de legitimação da decisão. Para os mais céticos decisionistas, a norma geral sequer fixa os limites da interpretação, servindo quando muito para justificar a posteriori uma decisão já tomada com base em normas ocultas pelos próprios procedimentos decisórios. ${ }^{15}$

Também, é da equivocada concepção de que a interpretação constitui mera operação de subsunção que se opera na hermenêutica tradicional ${ }^{16}$ a separação entre interpretação e aplicação, o que é, conforme insiste Eros Grau ${ }^{17}$, totalmente implausível uma vez que interpretação e aplicação não se realizam autonomamente como se duas atividades distintas fossem. ${ }^{18}$

Assim, Müller, diante da controvérsia vista nos séculos passados, entre o desígnio de se estabelecer uma interpretação que fosse objetiva e o reconhecimento dessa impossibilidade em face da inevitável subjetividade proveniente do intérprete, defende a tese de que a norma é produzida por um processo complexo que ultrapassa para além das

${ }^{15}$ J. M. ADEODATO, Ética e retórica..., op. cit., pp. 224-225.

${ }^{16}$ Para um estudo detalhado sobre as escolas da chamada 'Hermenêtica Tradicional' ver: J. M. A. DE ANDRADE, Interpretação da Norma Tributária, São Paulo, MP Editora, 2006, pp. 35-57; A. CASTANHEIRA NEVES, Digesta, v.2, Coimbra, Editora Coimbra, 1995, pp. 181-248; F. WIEACKER, História do direito privado moderno, 2. ed., Lisboa, Calouste Gulbenkian, 1993.

17 E. R. GRAU, Ensaio e discurso sobre a interpretação/aplicação do direito, 4.ed., São Paulo, Malheiros Editores, 2006, p. 35.

${ }^{18} \mathrm{O}$ presente trabalho não tem como objeto o estudo da evolução das referidas escolas da chamada Hermenêutica Tradicional, por uma opção de enfoque em face dos objetivos nele estabelecidos, contudo segue uma breve citação para registro e reavivo da memória. Sobre as Escolas da Exegese, Histórica e dos Interesses em A. CASTANHEIRA NEVES, Digesta, op. cit., pp. 181-184: "Designa-se por <<escola da exegese>> (L'école de l'exégese) uma corrente do pensamento jurídico francês, nascida nos começos do século XIX, que subsistiu, com maior ou menor fidelidade ao seu sentido originário, por todo esse século e em que encontrou expressão doutrinária e metodológica o legalismo da codificação pós-revolucionária. ...Foram três os seus postulados capitais. Desde logo, o que era directa expressão do legalismo pressuposto e que se enunciava na identificação do direito com a lei: o direito manifestar-se-ia unicamente nas leis e não haveria outro direito além daquele que as leis prescrevessem. ...Um outro postulado era o da exclusividade da lei como critério jurídico. ...um último postulado - o postulado da suficiência da lei, do Code civil, para dar solução a todos os casos jurídicos. Por outras palavras, o postulado da exclusão de lacunas no sistema da lei civil codificada."; sobre a Escola Histórica do Direito, em A. CASTANHEIRA NEVES, Digesta, op. cit., pp. 203-206: "Espressão particular, no âmbito do pensamento jurídico, do vasto movimento cultural alemão surgido na última parte do século XVIII e nos começos do século XIX e que, sob a designação genérica de $<<$ escola histórica $>>$, atingiu todos os domínios culturais, desde o pensamento filosófico à arte e à ciência, desde a história e a filologia à economia. ...Foi no contexto cultural aludido e através sobretudo da obra destes autores que a escola histórica vei enunciar o postulado fundamental do seu entendimento do direito como uma normativa realidade histórico-cultural que se manifesta na vida historicamente real de um $<<$ povo $>>$...”; e, no tocante à escola da Jurisprudência dos Interesses, em A. CASTANHEIRA NEVES, Digesta, op. cit., p.215: “...A jurisprudência dos interesses ... é uma corrente da metodologia jurídica que se impôs a partir do começo do nosso século... e orientou decisivamente o pensamento jurídico europeu continental... no sentido de uma intenção prático-teleológica...”. 
fronteiras postas pelo texto da Constituição e das leis em geral, mas que, por outro lado, não implica tornar a interpretação uma atividade incontrolável, deixada sob a total discricionariedade do intérprete. ${ }^{19}$

No positivismo jurídico, especialmente em Kelsen, a positividade se estende apenas até o âmbito de várias soluções logicamente possíveis, resignando-se a sentença judicial ou outro ato de geração de uma norma individual, a ser instituído ainda, à mera decisão volitiva. Kelsen compreende, portanto, como pressuposto da possibilidade de uma interpretação, a existência de várias soluções possíveis deixadas em aberto pela norma interpretada, que ainda será aplicada e, somente então, individualizada. Para Müller, tal enfoque permite compreender porque a teoria pura do direito não pode dar nenhuma contribuição para uma teoria aproveitável da interpretação. ${ }^{20}$

Para ele, "o positivismo jurídico, ao conceber o direito como um sistema sem lacunas, a decisão como uma subsunção estritamente lógica e com a supressão de todos os elementos do ordenamento social, não espelhados no texto da norma, deixa-se levar por uma ficção inaceitável na prática. Inclusive na afirmação de Kelsen, segundo a qual norma e realidade normatizada coexistem sem guardar nenhuma relação entre si, manifesta-se o erro de uma proposição que, indistintamente, aplica ao direito um conceito da ciência atualmente em desuso, inclusive no terreno das ciências naturais, em lugar de analisar diretamente as características próprias da normatividade jurídica, baseando-se para isso na aplicação concreta das normas jurídicas". ${ }^{21}$

Assim, continua ele, "é necessária uma nova teoria do direito, que conceba o trabalho jurídico como um processo a ser realizado no tempo, e os enunciados nas codificações como textos de normas, i.e., como pré-formas legislatórias da norma jurídica, que por sua vez está por ser produzida no decurso temporal da decisão. De outro modo, a norma jurídica não existe 'ante casum': o caso da decisão é co-constitutivo. O texto da norma no Código legal é apenas um dado de entrada do processo de trabalho chamado 'concretização", 22

\footnotetext{
${ }^{19}$ J. M. ADEODATO, Ética e retórica..., op. cit., p. 225.

${ }^{20}$ F. MÜLLER, Strukturierende Rechtslehre, trad. port. de P. Naumann e E. A. de Souza, Teoria Estruturante do Direito, São Paulo, Revista dos Tribunais, 2008, p.28.

${ }^{21}$ F. MÜLLER, Teoria Estruturante da Norma Jurídica e do Direito, trad. port. de R. I. Jansen dos Santos, in $O$ Novo Paradigma do Direito - Introdução à teoria e metódica estruturantes do direito, São Paulo, Revista dos Tribunais, 2007, pp. 19-20.

${ }^{22}$ F. MÜLLER, O Novo Paradigma do Direito - Introdução à teoria e metódica estruturantes do direito, trad. port. de P. Naumann, São Paulo, Revista dos Tribunais, 2007, p. 11.
} 
Portanto, ao contrário do que estabelece a concepção positivista, a norma jurídica não pode de modo algum ser tomada como "uma ordem abstrata daquilo que deve ser", muito menos como um "juízo hipotético ou um ato de vontade carente de inteiro fundo material". 23

A tese de Müller é a de que o texto e a realidade estão em constante relação recíproca, sendo exatamente tal relação, embora podendo apresentar alguma desconformidade ao final, a responsável pelo forjamento da norma jurídica. Com isso, se quer dizer que não só a norma do caso concreto é construída a partir do caso, mas também o é a norma aparentemente genérica e abstrata. Com outras palavras, a norma geral não é prévia, somente o seu texto é prévio, existe antes do caso concreto. ${ }^{24}$

É por isso que perde todo o sentido a discussão sobre o papel que o juiz tem de verdadeiramente criar a norma jurídica. De fato, não há dúvida do papel criador por parte do juiz, até porque não existe a norma geral (Rechtsnorm) previamente dada, já que também a norma geral somente será criada após o trabalho de concretização, levado a cabo pelo próprio juiz. ${ }^{25}$

Por outro lado, se é o juiz que cria a norma jurídica, então o que faz o legislador? O legislador, sobretudo o constituinte, até mesmo o constituinte originário, é o responsável pela produção do texto legal ou constitucional, não da norma propriamente dita, nem sequer da moldura dentro da qual se situam as interpretações devidas, uma vez que, conforme se verá a seguir, os textos normativos constituem apenas um dos dados de entrada do processo de concretização normativa. ${ }^{26}$

A norma vai sendo construída pelo intérprete no decorrer do processo de concretização do direito. A concretização implica um caminhar, do texto da norma e dos fatos, na direção da norma jurídica, que ainda não é o destino a ser alcançado, uma vez que a concretização somente se realiza plenamente quando, por fim, é definida a norma de decisão, apta a dar solução ao conflito que consubstancia o caso concreto. ${ }^{27}$

Do quanto foi dito até este ponto, em especial no parágrafo anterior, já se pode ter uma noção de que é esse o referencial que se pretende adotar: uma teoria 'concretivista' da interpretação/aplicação do direito, para levar a cabo o objetivo de analisar a argumentação

\footnotetext{
${ }^{23}$ F. MÜLLER, Teoria Estruturante da Norma..., op. cit., p. 20.

${ }^{24}$ J. M. ADEODATO, Ética e retórica..., op. cit., p. 237.

${ }^{25}$ J. M. ADEODATO, Ética e retórica..., op. cit., p. 237.

${ }^{26}$ J. M. ADEODATO, Ética e retórica..., op. cit., p. 238.

${ }^{27}$ E. R. GRAU, Ensaio e discurso..., op. cit., p. 29.
} 
utilizada na interpretação da ordem econômica em sede constitucional efetuada em casos concretos pela Corte Constitucional pátria. E, enfatiza-se, a metodologia, ou metódica jurídica, que adotaremos é aquela subjacente a essa teoria, a qual Müller designa de Metódica Estruturante, vista com maior vagar nas seções que seguem.

\subsection{A Metódica Jurídica e o Trabalho Jurídico}

Ao desenvolver a sua metódica jurídica, Müller nos fornece uma interessante visão do direito, subjacente aos elementos conceituais por ele concebidos. Diz ele que "o direito veicula a violência social especificamente formalizada e está ligado necessariamente à linguagem e, consequentemente, às suas condições gerais. A prática jurídica é uma técnica decisória politicamente funcional e a metódica jurídica é a técnica de atribuição da ciência prática no âmbito desses processos decisórios, ou seja, a metódica jurídica é a técnica da recondução, regular e aceita no caso normal, de normas decisórias a normas jurídicas". ${ }^{28}$

Assim, continua ele, "a metódica jurídica tem um significado diretamente político em decorrência do fato de o estado constitucional liberal pretender funcionar tão amplamente quanto possível com o recurso da 'violência constitucional' vazada na forma do direito e conseqüentemente veiculada pela linguagem". ${ }^{29}$

E ainda, quanto à delimitação do objeto do direito, sustenta ele que "os critérios correntes da epistemologia geral para separar as ciências naturais das humanas, tais como absoluto e relativo, objetivo e subjetivo, quantificador e qualificador, evidenciaram serem simplificações grosseiras, insustentáveis por ambas as partes. Não só nas ciências humanas a conceitualização depende da formulação dos problemas; não só nelas a qualidade de um estado de coisas investigado é condicionada pela direção do interesse do conhecimento. Por outro lado, o objeto 'em si' também não é acessível à ciência natural, de modo que a busca de critérios absolutos não faz mais sentido na ciência". ${ }^{30}$

Diante disso, a metódica jurídica não pode se iniciar com a indagação sobre que espécie de ciência entre as ciências é a dogmática jurídica, mas sim, por outro lado, a metódica jurídica deve ter como indagação primordial o que ocorre efetivamente quando um determinado ordenamento jurídico está em funcionamento, isto é, quando ele tem vigência. ${ }^{31}$

\footnotetext{
${ }^{28}$ F. MÜLLER, Direito, linguagem, violência, trad. port. de P. Naumann, in O Novo Paradigma do Direito Introdução à teoria e metódica estruturantes do direito, São Paulo, Revista dos Tribunais, 2007, pp. 195-196.

${ }^{29}$ F. MÜLLER, Direito, linguagem, violência..., op. cit., p. 196.

${ }^{30}$ F. MÜLLER, Direito, linguagem, violência..., op. cit., p. 201.

${ }^{31}$ F. MÜLLER, Direito, linguagem, violência..., op. cit., p. 201.
} 
Um ordenamento jurídico está em funcionamento quando, por exemplo, um certo Sr. A interessa-se por detalhes do matrimônio do Sr. e Sra. B, investiga fatos, procura correlacionar esses fatos a determinados textos, atua de acordo com determinado procedimento que está igualmente fixado em textos e que determina pelo que ele deve se interessar, o que deve selecionar e o que não deve selecionar, o que é relevante e o que é irrelevante, e quais conclusões devem por fim ser extraídas em termos reais com relação à continuidade do matrimônio em questão. ${ }^{32}$

Tais questões são fixadas em textos, que, por sua vez, têm as condições de sua formação e de sua validade e a possibilidade de seu controle ou de sua modificação determinados por outro texto, sendo todos eles textos de normas, ou seja, o teor literal de normas jurídicas positivas. Porém, não são esses textos que regulamentam os casos, mas, muito pelo contrário, pessoas motivadas de determinada maneira. ${ }^{33}$

Assim, é a ação do Sr. A, na condição de juiz de família, que, mediada pela ação de outras pessoas: escrivães, oficiais de justiça etc., faz mudar alguma coisa em termos reais no matrimônio considerado, ao exercer o seu cargo de forma relevante, se ater às normas procedimentais, avaliar o caso com base em normas vigentes etc. Essa 'faticidade', por sua vez, é mediada multiplamente pela linguagem, “já que a sociedade, a 'política', a dominação sempre representam, como processos comunicativos entre homens, também mediações por meio da linguagem". ${ }^{34}$

Contudo, essa 'faticidade' é duplamente restrita uma vez que, em primeiro lugar, ela é exógena, ou seja, não pertence à forma de linguagem das normas em questão, e, em segundo lugar, com relação à questão de uma sanção em caso de conflito, de um nãofuncionamento do ordenamento, ela se baseia em uma 'violência ${ }^{35}$ não-linguística', embora seja a violência mediada parcialmente pela linguagem uma vez que transcorre por meio de uma sentença, um mandado, uma ordem etc. Assim, quando o ordenamento funciona dá-se a violência constitucional institucionalizada, quando não funciona dá-se a violência corrente,

\footnotetext{
${ }^{32}$ F. MÜLLER, Direito, linguagem, violência..., op. cit., p. 204.

${ }^{33}$ F. MÜLLER, Direito, linguagem, violência..., op. cit., p. 205.

${ }^{34}$ F. MÜLLER, Direito, linguagem, violência..., op. cit., p. 205.

${ }^{35}$ Em F. MÜLLER, Direito, linguagem, violência..., op. cit., p. 206, nota do tradutor $\mathrm{n}^{\mathrm{o}} 05$, o tradutor explica a utilização do termo 'violência' em face da ambigüidade da expressão utilizada pelo autor em sua língua mãe: 'Gewalt'. Esse termo "pode ser traduzido por violência e por poder. A ambivalência do termo revela a ambivalência da própria realidade, à qual o termo se refere: o termo alemão admite, por assim dizer, que o poder tem necessariamente uma conotação de violência, ainda que a idéia e a práxis do Estado de Direito se empenhem em formalizar, vale dizer, racionalizar e assim tornar transparente e discutível essa violência constitutiva das relações sociais."
} 
atual, realizada em cada caso. ${ }^{36}$

Também por esse motivo, o texto normativo diferencia-se de outras linguagens, uma vez que, de sua 'leitura autêntica', produz ele uma violência não-lingüística, já referida. ${ }^{37}$

Assim, como nota conclusiva do que foi dito até aqui, temos que, nas palavras de Müller, "só se pode falar em uma metódica jurídica como práxis metódica, como modo de trabalho cotidiano de 'trabalhadores jurídicos"38, de titulares profissionais de funções tais como juízes, funcionários administrativos, promotores públicos, membros de órgãos legislativos, etc. ${ }^{39}$ Não se pode falar de uma metódica jurídica 'como tal' no sentido de uma área de análise abstratamente delimitável, de modo que se torna sem sentido uma indagação do lugar da metódica jurídica, epistemologicamente considerado". ${ }^{40}$

Mais uma vez nas palavras do mentor da teoria estruturante, "a metódica jurídica refere-se aos modos efetivos de trabalho de um setor da práxis social com determinadas tarefas, determinados procedimentos, possibilidade específicas de modificação e controle". 41

${ }^{36}$ F. MÜLLER, Direito, linguagem, violência ..., op. cit., pp. 205-206.

${ }^{37}$ J. M. A. DE ANDRADE, Interpretação..., op. cit., p. 150.

${ }^{38}$ F. MÜLLER, Direito, linguagem, violência..., op. cit., pp. 207-208. Aqui o autor oferece esclarecedora explicação a respeito dos 'trabalhadores jurídicos': “a) No tipo de sociedade, ao qual pertence a nossa, há entre outras normas sociais aquelas que são caracterizadas como 'obrigatoriamente válidas' pela violência constitucional, que é, em caso de conflito, violência atual. Esse fato é tanto garantido quanto legitimado pela estrutura organizacional do 'Estado'. Além disso, as normas aqui aludidas distinguem-se de outras normas sociais por apresentarem um teor literal obrigatoriamente 'válido', i.e., fixado com força de autoridade numa única redação determinada, um 'texto de norma'. Também esse fato mencionado por último está garantido por outras normas (e pela sua imposição violenta em caso de conflito). b) Há 'funções', que atualizam o conjunto de fatos fixado na forma de instituições e cargos, que efetivam, portanto, a 'validade' das normas na práxis. c) De um modo relevante no sentido das posições ' $a$ ' e ' $b$ ', funcionários profissionais, 'juristas', ocupam-se com esses textos das normas; se quisermos cunhar um termo mais genérico a partir da função social efetiva, podemos designá-los 'trabalhadores jurídicos' [Rechtsarbeiter]. d) O seu trabalho com referência ao ordenamento jurídico, i.e., à totalidade 'em funcionamento'das normas relativas a 'a-c' (relativas às regulamentações de conteúdo, às regras procedimentais, às instituições, aos cargos públicos profissionalizados) é sempre um trabalho com referência à sociedade, dotado de caráter decisório."

${ }^{39}$ Nesse ponto, vale lembrar a reflexão proposta por EROS GRAU, em Ensaio e discurso..., op. cit., pp. 66-67: "A um outro ponto devo ainda, introdutoriamente, aludir para distinguir a interpretação desenvolvida pelos juízes (intérpretes autênticos) dos exercícios de interpretação praticados pelos demais operadores do direito e pela doutrina. Estes últimos - operadores do direito e juristas - não são dotados do poder de praticar o ato decisional, momento final da atividade de interpretação do direito. $\mathrm{O}$ único intérprete autorizado pelo próprio direito a definir, em cada caso, a norma de decisão é o juiz. Logo, poderemos, para apartá-las, afirmar que a atividade (= conjunto de atos) de interpretação empreendida pelos demais operadores do direito e pelos juristas cessa no momento anterior ao da definição da norma de decisão, ato privativo do intérprete autêntico". Conforme dito no capítulo de introdução deste trabalho, está ele desenvolvido sobre o enfoque da interpretação realizada pelos 'intérpretes autênticos' kelsenianos, ou melhor, na concepção de Müller, pelos 'trabalhadores jurídicos', de modo que a discussão levantada por GRAU, citada acima, referente à interpretação promovida pelos demais operadores do direito, não é aqui abordada por extrapolar os objetivos propostos para o presente trabalho.

${ }^{40}$ F. MÜLLER, Direito, linguagem, violência..., op. cit., p. 212.

${ }^{41}$ F. MÜLLER, Direito, linguagem, violência..., op. cit., p. 212. 
Lembra Eros Grau que é um trabalho artesanal o trabalho jurídico de construção da norma aplicável a cada caso. Assim, ele enfatiza: a interpretação do direito, tomando interpretação na acepção aqui dada, como construção normativa e, precisamente, como o próprio trabalho jurídico, não constitui um mero exercício de leitura de textos de lei, "para o quê bastaria ao intérprete ser alfabetizado”, mas constitui a atividade do trabalhador jurídico de obter a solução jurídica, para cada caso, que "será sempre, renovadamente, uma nova solução". 42

Diante disso, a metódica jurídica, conforme defendido por Müller, não pode se basear em indagações puramente jurídicas, que são tratadas apenas a partir da tecnicidade profissional, passando ao largo das condições políticas e sociais existentes. Por outro lado, não satisfaz as condições de segurança e controle uma teoria que se baseia única e exclusivamente no chamado decisionismo, que tem como desígnio o sustentáculo da solução do caso em uma decisão de caráter meramente político. ${ }^{43}$

Nas palavras de Müller, é também insuficiente um "enfoque essencialista do direito por meio de uma suposição ontologicizante sem mediações; é insuficiente um enfoque de tradição marxista que concebe o ordenamento jurídico, o trabalho jurídico e a metódica jurídica como instrumento para a manutenção das relações de classes; é insuficiente um enfoque que pretende determinar a metódica do trabalho jurídico apenas a partir dos problemas textuais, como se dá com a filosofia analítica da linguagem, a teoria da informação, e com generalizações de enfoques do processamento eletrônico de dados para a metódica jurídica". ${ }^{44}$

É assim que, para Müller, a função da metódica jurídica, em termos da teoria jurídica, deve consistir em "elaborar, formular regras para a imputação das normas de decisão estabelecidas nos casos concretos às normas jurídicas gerais indicadas como existentes por trás dessas normas de decisão, de modo que a solução de casos jurídicos é uma técnica decisória, a metódica jurídica como metódica da fundamentação explanadora da decisão é uma técnica de imputação". ${ }^{45}$

Em termos políticos, a função da metódica jurídica consistiria em “deslocar, de maneira bem-sucedida, porque regularmente aceita como plausível, a responsabilidade pela decisão, pela orientação, pela distribuição, pela dominação funcionalmente pessoal no caso

\footnotetext{
${ }^{42}$ E. R. GRAU, Ensaio e discurso..., op. cit., p. 36.

${ }^{43}$ F. MÜLLER, Direito, linguagem, violência..., op. cit., p. 209.

${ }^{44}$ F. MÜLLER, Direito, linguagem, violência..., op. cit., p. 209.

${ }^{45}$ F. MÜLLER, Direito, linguagem, violência..., op. cit., p. 213.
} 
individual para instâncias mais distantes, como o 'legislador' e o judiciário de instância suprema, de modo que a instrumentalidade da metódica jurídica consiste em dar à sociedade econômica e comercial burguesa a calculabilidade, transparência e regularidade efetivamente necessárias, produzindo um efeito legitimador à medida que a transparência dos processos decisórios ou ao menos das razões da decisão devam tornar a decisão acessível à crítica e ao controle". ${ }^{46}$

\subsection{Jogos de Linguagem e Pré-compreensão}

Até aqui, já expusemos as linhas gerais da metódica jurídica pensada por Müller, porém, antes de prosseguirmos na apresentação da estrutura da norma e do seu processo de concreção, importa tecer algumas observações a respeito dos fundamentos teóricos da própria Metódica Estruturante, em especial aqueles provenientes da filosofia analítica de Wittgenstein e da 'Hermenêutica Filosófica' de Gadamer.

Pois bem, a Metódica Estruturante, ao ser concebida a partir de um modo efetivo de produzir efeitos, próprio do ordenamento jurídico, e não a partir de um esquema epistemológico abstrato, conforme posto linhas atrás, sugere ${ }^{47}$ que palavras e expressões presentes nos textos normativos, ao contrário de uma concepção representacionalista da linguagem $^{48}$, não têm um significado 'em si', que possam ser extraídos por meio da interpretação, mas têm o seu significado construído a partir de seus usos, dentro do jogo de linguagem ${ }^{49}$ que está em funcionamento, conforme concepção estabelecida na segunda fase

${ }^{46}$ F. MÜLLER, Direito, linguagem, violência..., op. cit., p. 213.

${ }^{47}$ F. MÜLLER, Direito, linguagem, violência..., op. cit., p. 219.

${ }^{48}$ J. M. A. DE ANDRADE, Interpretação..., op. cit., p. 58. José Maria A. de Andrade explica que utilizar a palavra 'representação' significa dizer que os termos da linguagem, e os textos normativos também, uma vez que são estes formados por aqueles e, portanto, tem deles a mesma natureza, têm a propriedade de apontar para elementos da natureza, das coisas ou das idéias, permitindo que sujeitos cognoscitivos assimilem ou alcancem seu conteúdo preexistente.

${ }^{49}$ A palavra 'jogos' na expressão 'jogos de linguagem' foi adotada por Wittgenstein para realçar o fato de que a linguagem é uma atividade ou uma forma de vida. Em N. ABBAGNANO, História..., op. cit., p. 154, é criticado o uso dessa palavra uma vez que ela traz uma conotação de que o jogo é uma atividade que se exerce por si mesma e não para atingir um fim qualquer. Assim, se a linguagem fosse um jogo seria um fim e não um instrumento como é sustentado na própria teoria de Wittgenstein. Aclarando mais o conceito, em P. M. S. HACKER, Wittgenstein - On Human Nature, 1997, trad. port. de J. V. Gallenari Cuter, Wittgenstein - sobre a natureza humana, São Paulo, UNESP, 2000, p. 13, “jogos de linguagem: as práticas, atividades, ações e reações em contextos característicos, dos quais o uso regrado das palavras é parte integrante. Estas descrições e as explicações de significado associadas a elas não são uma filosofia, mas uma metodologia. Segundo Wittgenstein, o que elas têm de tipicamente filosófico é o propósito a que servem. Descrever os usos das palavras é desemaranhar confusões conceituais - confusões que surgem, entre outros motivos, pelo desapercebido uso incorreto das palavras." Em H. J. GLOCK, Dicionário Wittgenstein, trad. port. de H. Martins, Rio de Janeiro, Jorge Zahar Editor, 1998, pp. 225-226, o ponto de partida para a analogia entre jogo e linguagem consiste em que assim como os jogos "a linguagem é uma atividade guiada por regras. (a) Assim como um jogo, a linguagem possui regras constitutivas, as regras da GRAMÁTICA. Distinguindo-se de regras 
da filosofia de Wittgenstein ${ }^{50}$, com o advento das 'Investigações Filosóficas" ${ }^{51}$.

Por exemplo, palavras e expressões como 'residência' e 'invadir', no direito penal, e 'aptidão' e 'grave violação de obrigação matrimonial', no direito de família, tem o seu significado conforme o seu uso dentro do jogo de linguagem que está em funcionamento nesses campos do direito. ${ }^{52}$

Entretanto, a Metódica Estruturante não busca uma filiação filosófica irrestrita, mas tão somente a apropriação de parte do referencial teórico da filosofia analítica de Wittgenstein, sobretudo, no sentido de uma concepção da interpretação como um processo construtivo do objeto interpretado e não como um processo em que se acessa um dado preexistente no objeto que se interpreta. Como resultado, também se fundamenta numa compreensão do processo interpretativo dos textos de lei como indissociável da ideia de que a linguagem funciona em seus usos, no âmbito dos jogos de linguagem em funcionamento.

Nesse sentido, assevera José Maria A. de $A_{n d r a d e}^{53}$ que, ao elaborar o seu ferramental metodológico, Friedrich Müller não assume decididamente uma pauta não representacionalista para a hermenêutica jurídica e, nesse aspecto, afasta-se de um maior comprometimento com o referencial wittgensteiniano.

De fato, o próprio Müller adverte que, aqui, não se trata de se apropriar da teoria de Wittgenstein, explorando sua fecundidade para a ciência jurídica, mas de fazer uso dessa estrutura conceitual da filosofia analítica da linguagem para reconhecer eventualmente, em uma forma mais genérica e em um grau de abstração mais elevado, “as observações que podem ser feitas numa análise imanente das funções, das estruturas e dos modos de trabalho efetivos do universo jurídico". ${ }^{54}$

estratégicas, as regras gramaticais não determinam que lance/proferimento terá êxito, mas sim aquilo que é correto ou faz sentido, definindo, dessa forma, o jogo/linguagem. (b) O significado de uma palavra não é uim objeto do qual ela é um sucedâneo, sendo antes determinado pelas regras que governam seu funcionamento ... Aprendemos o significado das palavras aprendendo a utilizá-las, da mesma forma que aprendemos a jogar xadrez, não pela associação de peças a objetos, mas sim pelo aprendizado dos movimentos possíveis para tais peças... (c) Uma proposição constitui um lance ou uma operação no jogo da linguagem; seria destituída de significado na ausência do sistema de que faz parte. Seu sentido é o papel que desempenha na atividade lingüística em curso...".

${ }^{50}$ N. ABBAGNANO, História da filosofia, v.11, 4. ed., Lisboa, Editorial Presença, 2000, pp. 150-151. Após dez anos de afastamento do trabalho acadêmico, em 1929, Wittgenstein retorna e põe em dúvida a consistência do sistema construído no Tractatus, iniciando a sua segunda fase que culminou com a publicação póstuma da obra 'Investigações Filosóficas'.

51 L. WITTGENSTEIN, Philosophische Untersuchungen, 1958, trad. port. de M. G. Montagnoli, Investigações Filosóficas, 5.ed., Bragança Paulista, Editora Universitária São Francisco - Petrópolis, Vozes, 2008.

${ }^{52}$ F. MÜLLER, Direito, linguagem, violência..., op. cit., p. 219.

${ }^{53}$ Interpretação..., op. cit., p. 157.

${ }^{54}$ F. MÜLLER, Direito, linguagem, violência..., op. cit., p. 220. 
Da mesma forma, entra na Metódica Estruturante, de modo que ela constate a confirmação da sua experiência imanente do trabalhar o ordenamento jurídico, a chamada 'Hermenêutica Filosófica' de H. G. Gadamer, uma vez que, de acordo com essa escola, a compreensão é um acontecimento atual. Ou seja, a descoberta do sentido e a aplicação estão inseparavelmente reunidas num processo unitário que inclui necessariamente o 'sujeito compreendente' e sem o qual o sentido do texto a ser compreendido nem poderia ser concretizado e nessa medida completado. ${ }^{55}$

Cumpre observar que, embora o material de trabalho de Gadamer não seja o da ciência jurídica, "nela são substancialmente agudizadas a atualidade da compreensão e a précompreensão que envolve o intérprete e o objeto da interpretação, em virtude da referência social do trabalho jurídico, da sua formalização específica, do seu grau decisivamente elevado de obrigatoriedade e da sua relevância para a decisão "válida", ${ }^{56}$

Afirma Müller que "diante da pré-compreensão geral - constituída pelos conteúdos, modos de comportamento, preconceitos, pelas normas, possibilidades de expressão lingüística e barreiras lingüísticas da camada social, à qual o indivíduo pertence coloca-se uma pré-compreensão específica jurídica e de teoria jurídica, cujos pontos referenciais principais são normas 'vigentes', i.e., normas sancionáveis com violência e tentativas de sua sistematização científica ou 'teorias".".57

Dito de outro modo, o processo de interpretação dos textos normativos encontra na pré-compreensão o seu momento inicial, a partir do qual ganha dinamismo um movimento circular, que compõe o círculo hermenêutico. Não há como ser diferente uma vez que, conforme defende Eros Grau, “o juiz decide sempre dentro de uma situação histórica determinada, participando da consciência social de seu tempo, considerando o direito todo, e não apenas um determinado texto normativo". ${ }^{58}$

Também, a tese da inseparabilidade da interpretação e da aplicação, cara à concepção hermenêutica de Müller, está apoiada no ponto de vista central do referencial teórico da Hermenêutica Filosófica: a compreensão como processo atual, ou por outras palavras, o reconhecimento de sentido e a aplicação inseparáveis num processo unitário, que inclui necessariamente o sujeito compreendente e concretiza e leva a termo em primeira instância esse sentido a ser entendido, não obstante a simultânea vinculação integral ao

\footnotetext{
${ }^{55}$ F. MÜLLER, Direito, linguagem, violência..., op. cit., p. 222.

${ }^{56}$ F. MÜLLER, Direito, linguagem, violência..., op. cit., p. 223.

${ }^{57}$ F. MÜLLER, Direito, linguagem, violência..., op. cit., p. 223.

${ }^{58}$ E. R. GRAU, Ensaio e discurso..., op. cit., p. 41.
} 
sentido do texto. ${ }^{59}$

Por fim, a mesma advertência feita por Müller sobre a filosofia analítica da linguagem, afirma ele, também vale para a 'Hermenêutica Filosófica' em razão de que, aqui, não se trata de justificar a adoção da presente metódica jurídica por meio de tais concepções filosóficas, mas de reconhecê-la e analisá-la em patamares maiores de abstração. É por tal motivo que, também no presente trabalho, nossa abordagem de tais concepções, em especial da 'Hermenêutica Filosófica', foi propositalmente incipiente, apenas para deixar esclarecidos termos, como 'pré-compreensão', que venham a ser utilizados quando da exposição da Metódica Estruturante.

\subsection{A Estrutura da Norma}

Prosseguindo, nesta seção traçaremos um esboço da estrutura normativa concebida pela Metódica Estruturante e na próxima seção apresentaremos o seu processo de concreção normativa.

A normatividade, a ser determinada conforme os pressupostos teóricos que foram vistos até aqui, corresponde a uma específica estrutura normativa, ou, em outras palavras, a uma estrutura interna específica do trabalho jurídico. Os elementos da estrutura da norma jurídica, a serem apresentados a seguir, são o 'programa da norma' e o 'âmbito da norma' (ou 'área da norma'). ${ }^{60}$

O 'programa da norma' é a composição do teor literal da norma jurídica, o texto de lei, com todos os recursos interpretativos auxiliares considerados em conjunto e determinando uns aos outros. O 'âmbito da norma', pertencente à norma como mesmo grau hierárquico do 'programa da norma', “é a estrutura básica do segmento da realidade social”, selecionada por meio do 'programa da norma' como a sua área de regulamentação ou, mesmo, criada em parte pelo 'programa da norma', como se verá posteriormente ${ }^{61}$. A relação 'programa da norma' - 'âmbito da norma' guarda uma certa analogia com as relações presentes na Hermenêutica Filosófica do 'teor literal e sentido', 'evocação e redundâncias', 'configuração lingüística e referência material'. ${ }^{62}$

\footnotetext{
${ }^{59}$ F. MÜLLER, Strukturierende Rechtslehre..., op. cit., p. 55.

${ }^{60}$ F. MÜLLER, Direito, linguagem, violência..., op. cit., pp. 223-224.

${ }^{61}$ Aqui, 'criar' refere-se àquelas circunstâncias factuais que foram criadas pelo programa da norma, como, por exemplo, no caso da 'aptidão' para o serviço público.

${ }^{62}$ F. MÜLLER, Direito, linguagem, violência..., op. cit., p. 224.
} 
O âmbito da norma pode ser inteiramente gerado pelo direito, como no caso das normas sobre prazos, termos, formas, regras procedimentais e institucionais; ou, pode não ser gerado pelo direito em absolutamente nada, como é o caso da educação e da saúde tratadas no texto constitucional. ${ }^{63}$

O programa da norma é elaborado por meio de todos os métodos interpretativos reconhecidos, desde aqueles pertencentes aos cânones da hermenêutica, tais como as interpretações do tipo gramatical, genética, histórica e sistemática, até as figuras interpretativas específicas de grandes áreas do direito penal, do direito civil, da história do direito e do direito comparado. De modo diametralmente oposto, o 'âmbito da norma' é identificado, selecionado empiricamente, uma vez que corresponde ao dado material da prescrição jurídica. ${ }^{64}$

Assim, efetivamente a realidade não está segregada da norma jurídica, de modo que o texto normativo constitui apenas um de seus elementos. A não identificação entre texto e norma não significa a existência de dois planos distintos, uma vez que, como já dito, o primeiro é parte pertencente da segunda. Essa não identificação, que contrapõe a metódica estruturante à hermenêutica tradicional ${ }^{65}$, tem como razão de ser a evidenciação de dois tipos distintos de leitura do texto normativo, sendo a norma a leitura realizada quando da aplicação competente pelo órgão especializado.

Nesses termos é que se pode dizer que fica superada a separação tradicional entre os planos do ser e do dever-ser, de modo que a norma não poderá ser obtida em face de indagações abstratas no plano do dever-ser, mas sim por meio do processo de concreção normativa que se realiza quando e somente quando se aplica a norma ao caso. ${ }^{66}$

Com tal concretismo, evidenciado pela teoria de Müller, atingi-se um ponto em que o jurista, naturalmente, ao falar da Constituição, deve esquecer que está falando do texto da Constituição, e, do mesmo modo, ao falar da lei deve ter em mente que não é a letra da lei o objeto a que se refere. Nas palavras de Bonavides, "o verbalismo normativo é o somenos, o realismo extravocabular da norma é tudo". ${ }^{67}$

Neste ponto, interessante figura nos traz a mente Eros Grau afirmando que "As normas, portanto, resultam da interpretação. E o ordenamento, no seu valor histórico-concreto,

\footnotetext{
${ }^{63}$ F. MÜLLER, Direito, linguagem, violência..., op. cit., p. 224.

${ }^{64}$ F. MÜLLER, Direito, linguagem, violência..., op. cit., pp. 224-225.

${ }^{65}$ Vide notas de rodapé $\mathrm{n}^{\mathrm{o}} 16$ e 18.

${ }^{66}$ J. M. A. DE ANDRADE, Interpretação..., op. cit., p. 153.

${ }^{67}$ P. BONAVIDES, Curso de Direito Constitucional, 24. ed., São Paulo, Malheiros, 2009, pp. 504-505.
} 
é um conjunto de interpretações, isto é, conjunto de normas. O conjunto das disposições (textos, enunciados) é apenas ordenamento em potência, um conjunto de possibilidades de interpretação, um conjunto de normas potenciais". ${ }^{68}$

Grosso modo, o processo de concreção normativa tem início com o manuseio do texto normativo e, mediante a aplicação de procedimentos cognitivos sobre o conjunto de tais textos, por meio de recursos interpretativos, tanto aqueles ligados aos cânones hermenêuticos como quaisquer outros reconhecidos amplamente, obtém-se o 'programa da norma'. Por meio dele, e tendo em consideração a situação específica do caso em estudo, elabora-se o 'âmbito da norma', que é a estrutura básica do segmento da realidade regulada e obtida pelo 'programa da norma'. Contudo, deve-se ter em mente que o 'âmbito da norma' não se identifica com os elementos factuais particulares das circunstâncias da espécie. Pelo contrário, o ‘âmbito da norma' faz parte da própria estrutura da prescrição jurídica. ${ }^{69}$

Contudo, todos esses processos e elementos utilizados na concreção normativa, não têm caráter normativo uma vez que constituem apenas dados de entrada. O caráter normativo, a normatividade, somente nascerá quando, no processo de concreção normativa, forem obtidos os seus elementos finais: a norma jurídica e a norma-decisão, o que vale a dizer, de outro modo, que somente elas possuem normatividade. Os textos normativos não possuem, portanto, normatividade, contudo possuem validade, o que, nada obstante, confere a eles a necessidade de serem observados e respeitados. ${ }^{70}$

Assim é que, contrário a todas as correntes hermenêuticas tradicionais, positivistas ou não, Müller sustenta que todos os procedimentos e elementos anteriores à norma jurídica e à norma-decisão, os quais têm a função de engendrar o 'programa da norma' e o 'âmbito da norma', constituem dados de entrada (Eingangsdaten) e não têm caráter normativo. A normatividade só aparece nos resultados da concretização, vale dizer, na norma jurídica (Rechtsnorm), como resultado intermediário, e na norma decisória (Entscheidungsnorm), o resultado final. ${ }^{71}$

A norma jurídica (Rechtsnorm) é exatamente o somatório do programa da norma e do âmbito da norma. Já a norma decisória (Entscheidungsnorm) é o teor da decisão, "por exemplo: o acusado foi declarado inocente e liberado; o réu deve pagar dez mil reais ao autor; o pai ficará com o filho nos dias de quinta-feira a sábado; e assim por diante. Essa norma

\footnotetext{
${ }^{68}$ E. R. GRAU, Ensaio e discurso..., op. cit., p. 85.

${ }^{69}$ J. M. A. DE ANDRADE, Interpretação..., op. cit., p. 154.

${ }^{70}$ J. M. A. DE ANDRADE, Interpretação..., op. cit., p. 156.

${ }^{71}$ J. M. ADEODATO, Ética e retórica..., op. cit., p. 248.
} 
decisória é o resultado final de todas as fases anteriores do trabalho jurídico de concretização". 72

Aqui, com o intuito de distinguir mais as figuras da norma jurídica e da normadecisão, tomaremos novamente como norte os dizeres de Eros Grau: "A concretização implica um caminhar do texto da norma para a norma concreta (norma jurídica), que não é ainda, todavia, o destino a ser alcançado; a concretização somente se realiza no passo seguinte, quando é descoberta a norma decisão, apta a dar solução ao conflito que consubstancia o caso concreto". ${ }^{73}$

Cumpre observar, ainda, que a norma jurídica e a norma-decisão ${ }^{74}$ também não $^{-}$ constituem entidades distintas. A norma-decisão representa o grau de condensação no qual se encontra, em cada caso, a norma jurídica, não constituindo, junto a esta, outra entidade independente. $^{75}$

A teoria jurídica edificada a partir da Metódica Estruturante de Müller estabelece, como conseqüência lógica, a diferença entre a validade, presente no texto normativo, e a normatividade, que somente se verifica na norma jurídica. Dito de outro modo, ao ser iniciado o 'trabalho com textos juridicos' (Rechtstext und Textarbeit), o seu dado primeiro, o texto da norma, não tem qualquer significado normativo, tem apenas validade uma vez que produzido sob determinadas condições. Essa validade significa que os destinatários do texto devem se conduzir de forma compatível com ele. ${ }^{76}$

Contudo, os destinatários do texto não são somente os leigos, mas o são também os profissionais do direito de um modo geral, e o juiz em particular, que, portanto, passam compulsoriamente a considerar tais textos como dado de entrada da

${ }^{72}$ J. M. ADEODATO, Ética e retórica..., op. cit., p. 248.

${ }^{73}$ E. R. GRAU, Ensaio e discurso..., op. cit., p. 79.

${ }^{74}$ Em J. M. ADEODATO, Ética e retórica..., op. cit., p. 249: "Fazendo uma comparação exemplificativa final, com o objetivo de tornar ainda mais clara uma forma complexa de colocar a hermenêutica contemporânea como é a de Friedrich Müller. Texto da norma (art. 155 do Código Penas brasileiro): 'Subtrair, para si ou para outrem, coisa alheia móvel. Pena - reclusão, de 1 (um) a 4 (quatro) anos, e multa' (destacado aqui). Norma jurídica, resultado de todo o trabalho de concretização anterior, vinculado a um caso concreto, no qual determinado sujeito fez ligação clandestina para obter eletricidade sem pagar por isso: 'No texto do artigo 155 do Código Penal brasileiro, o conceito de coisa refere-se a objetos físicos. Palpáveis, e o texto não se aplica quando o objeto em questão é energia elétrica'. Norma decisória, a partir da conclusão de que o caso sob exame é de furto de energia elétrica: 'O agora acusado fulano não sofrerá reclusão de 1 a 4 anos e multa e será inocentado'. Observe-se que é apenas um exemplo de uma concretização. A questão é controversa, provocando inclusive a adução do $\S 3^{\circ}$ ao referido artigo: 'Equipara-se à coisa móvel a energia elétrica ou qualquer outra que tenha valor econômico'. Sobre o problema do desvio de sinal de TV a cabo, por exemplo, a doutrina hoje debate se lhe aplicaria o conceito de energia, o que é decisivo para subsumir ao artigo do furto (155) ou do estelionato (171).”.

${ }^{75}$ F. MÜLLER, Teoria Estruturante da Norma..., op. cit., p. 29.

${ }^{76}$ J. M. ADEODATO, Ética e retórica..., op. cit., p. 249. 
concretização e a trabalhá-los de modo metodicamente correto, até obter a norma jurídica, momento em que aparece o caráter normativo. ${ }^{77}$

Nada obstante, observe-se que o conceito positivista de validade, entendido como o cumprimento de regras existentes no sistema jurídico, relativas a conteúdo, competência, rito de elaboração etc., é mantido inalterado na metódica estruturante, embora no positivismo se preste a qualificar a norma jurídica, ao passo que aqui tem a ver somente com o texto normativo. Porém, verifica-se que o conceito de validade da metódica estruturante não possui o conteúdo axiológico presente na Teoria do Discurso, em que a validade é concebida com o sentido de racionalidade, adequação, correção etc. ${ }^{78}$

\subsection{A Concreção Normativa}

Após avançarmos na Metódica Estruturante com a apresentação da estrutura da norma por ela concebida, trataremos em diante do processo de concreção normativa, cujo detalhamento, importa dar os créditos, foi melhor desenvolvido, inclusive com exemplos, por João Maurício Adeodato, no texto ${ }^{79}$ A Concreção Normativa, Um Estudo Crítico apresentado na obra Ética e Retórica, Para uma Teoria da Dogmática Jurídica, o qual utilizaremos como base para exposição que segue.

Pois bem, de início, cumpre ressaltar o alerta sinalizado por Müller de que o 'programa da norma' e o 'âmbito da norma' “não são meios para encontrar, à maneira do direito natural, verdadeiros enunciados ônticos de validade geral, tampouco ajudam a averiguar o 'verdadeiro sentido' dos textos normativos em termos do tipo definido e juridicamente 'correto' do uso da língua no respectivo contexto normativo" ${ }^{80}$

De fato, assevera José Maria Arruda de Andrade que a Metódica Estruturante baseia-se na adoção de um referencial teórico que busca se afastar de noções jurídicas universais e de teorias essencialistas, ontologicizantes, na formação da linguagem e em sua interpretação. $^{81}$

Dito isso, ingressaremos na apresentação do processo de concreção normativa

\footnotetext{
${ }^{77}$ J. M. ADEODATO, Ética e retórica..., op. cit., p. 249.

${ }^{78}$ J. M. ADEODATO, Ética e retórica..., op. cit., pp. 249-250.

${ }^{79}$ Esse texto já foi utilizado largamente como referência em vários parágrafos até aqui escritos e, como observa J. M. A. DE ANDRADE, Interpretação..., op. cit., p. 156, nota de rodapé n॰213, ele é um dos mais felizes na descrição dos elementos de concreção normativa da Metódica Estruturante.

${ }^{80}$ F. MÜLLER, Strukturierende Rechtslehre..., op. cit., p. 245.

${ }^{81}$ J. M. A. DE ANDRADE, Interpretação..., op. cit., p. 122.
} 
revelado pela Metódica Estruturante, afirmando que os elementos tradicionais de interpretação não são por ela abandonados, muito pelo contrário, a interpretação do texto da norma compreende os cânones da hermenêutica tradicional ${ }^{82}$, que, segundo a concepção de Müller, se compõem do método gramatical, do sistemático e do subjetivo. ${ }^{83}$

O elemento subjetivo, por sua vez, divide-se em duas partes: a histórica e a genética. A interpretação histórica constitui a análise de textos de normas anteriores àqueles envolvidos na concretização normativa do caso em estudo, muitas vezes não mais vigentes porque revogados pelos textos de normas do caso. A interpretação genética constitui a análise dos elementos e processos sociais que efetivamente produziram o texto de norma do caso em estudo, como, por exemplo, o são os anais da Constituinte que relatam as discussões e os motivos que redundaram na elaboração daquele texto. ${ }^{84}$

Portanto, como se vê, a interpretação é, para Müller, um conceito mais restrito que o do processo de concreção normativa. Enquanto o processo interpretativo é constituído apenas das possibilidades de trato jurídico, inclusive filológico, dos textos de norma, o processo de concretização normativa não se reduz à apenas o trato com textos normativos, já que, na concepção mülleriana, não há uma identificação biunívoca entre norma e texto, mas este, apenas como dado de entrada, pode-se dizer que faz parte daquela, de modo que, analogamente, a concretização vai muito além da interpretação, esta fazendo parte daquela. ${ }^{85}$

Assim, no início do processo de concretização são trabalhados os textos normativos por meio dos métodos interpretativos, gramáticos, sistemáticos, subjetivos e outros métodos e técnicas comumente conhecidas, obtendo-se os chamados pontos de vista interpretativos comuns os quais constituem os dados lingüísticos (Sprachdaten). Os dados lingüísticos são, portanto, primariamente fundamentados na linguagem e decorrem do trato jurídico com textos normativos. ${ }^{86}$

Porém, como já dito, a concreção normativa não se reduz ao trato com os textos jurídicos, pelo contrário, os elementos da realidade presentes no caso integram em igual importância a norma jurídica. Assim, os elementos naturais e sociais vão constituir os dados reais (Realdaten) da concretização, os quais não são primariamente fundamentados na linguagem, apenas o são secundariamente nela fundamentados, uma vez que necessariamente

\footnotetext{
${ }^{82}$ Vide notas de rodapé no 16 e 18.

${ }^{83}$ J. M. ADEODATO, Ética e retórica..., op. cit., p. 236.

${ }^{84}$ J. M. ADEODATO, Ética e retórica..., op. cit., p. 236.

${ }^{85}$ J. M. ADEODATO, Ética e retórica..., op. cit., p. 238.

${ }^{86}$ J. M. ADEODATO, Ética e retórica..., op. cit., p. 239.
} 
por ela intermediados. ${ }^{87}$ Veremos, posteriormente, que os dados reais formarão sucessivamente os elementos do âmbito do caso e do âmbito da norma.

Os dados lingüísticos e os dados reais são chamados de dados pré-jurídicos ${ }^{88}$, são na realidade o material bruto sobre o qual se debruçará o jurista no início do seu trabalho de concretização. Aqui, vale ressaltar que a Metódica Estruturante busca estabelecer uma metodologia que, ao trabalhar tais dados de entrada, busca conectá-los por meio de um procedimento juridicamente regular, evitando a forma arbitrária ou 'puramente pragmática' das teorias decisionistas. ${ }^{89}$

Pois bem, diante desses dados pré-jurídicos é selecionado o primeiro elemento especificamente jurídico, uma vez que obtido internamente, ou seja, dentro do processamento da concreção normativa, que constitui precisamente o conjunto de textos da norma (Normtextmenge, Normtext, Wortlaut). São eles os textos do ordenamento jurídico em geral, cujo sentido básico é contextualizado pelos dados reais e lingüísticos vinculados àquela determinada estrutura social. Aqui, deve-se ressaltar, os textos de norma não são a norma jurídica em si, nem constituem a moldura para solução do caso, nos termos do positivismo kelseniano. Deve-se entendê-los como uma primeira aproximação da estrutura da norma, que somente estará completamente revelada quando forem obtidos o programa da norma e o âmbito da norma, a serem vistos posteriormente, os quais, até por força do próprio método, não podem se apresentar incompatíveis com o primeiro elemento jurídico da concretização. ${ }^{90}$

Assim, o conjunto de textos de norma (Normtextmenge) é formado por textos do ordenamento jurídico, tais como: textos de leis, de processos, de acórdãos, de sentenças. Esses textos, como toda linguagem 'natural', são constituídos a partir dos dados lingüísticos e dos dados reais, isto é, da língua em que são escritos, respeitando suas regras de inteligibilidade, e do contexto fático em que atuam. O termo 'estupro' tem um feixe de

${ }^{87}$ J. M. ADEODATO, Ética e retórica..., op. cit., p. 239.

${ }^{88}$ Em J. M. ADEODATO, Ética e retórica..., op. cit., p. 239: "Embora Müller, seguindo a tradição alemã, não forneça exemplos, vai-se aqui arriscar alguns, visando tornar mais claro o procedimento. Alguns 'Sprachdaten': $m$ com u formam a sílaba um; 'Isabel viu Cristina' tem sentido diferente de 'Cristina viu Isabel' em decorrência da relação entre sujeito e objeto; 'para' é proposição usada nesse e nesse casos diferente de 'sobre' etc. $\mathrm{O}$ art, $14, \S 1^{\circ}$, II, b, da Constituição Federal disciplina que o voto dos maiores de 70 anos é facultativo. Ora, vai haver dúvidas hermenêuticas sobre a relação entre um caso e o texto, mas certamente 'facultativo' e 'obrigatório' têm sentidos diferentes na língua portuguesa. Alguns 'Realdaten': dois corpos não ocupam o mesmo lugar no espaço; há uma força gravitacional que atrai corpos para o solo; uma faca é capaz de penetrar em um corpo humano, a depender das condições; um lenço cai no chão com menos ruído do que um copo de vidro etc. No campo do direito, são dados reais as diferenças entre um ato de compra e venda e um de aluguel ou entre uma sociedade limitada ou por ações."

${ }^{89}$ J. M. ADEODATO, Ética e retórica..., op. cit., p. 239.

${ }^{90}$ J. M. ADEODATO, Ética e retórica..., op. cit., pp. 239-240. 
sentidos, 'matar' tem outro, 'alguém', outro ainda. São convencionais, mas não são casuística e arbitrariamente intercambiáveis. ${ }^{91}$

Prosseguindo, o segundo elemento especificamente jurídico é o relato sobre o caso (Fallerzählung). É um relato não profissional ${ }^{92}$ realizado por indivíduos, geralmente leigos, contudo já vem ele orientado por uma noção do sistema jurídico que todo indivíduo possui em maior ou menor profundidade. É, portanto, o meio pelo qual o caso em estudo chega ao conhecimento do profissional do direito. ${ }^{93}$

A partir daí, o jurista, por meio do seu trabalho profissional, portanto com base num conhecimento especializado, passa o relato sobre o caso para uma linguagem mais próxima da linguagem do direito, de modo que o relato leigo, por meio da interferência do conhecimento profissional do jurista, se transforma num relato técnico ao qual Müller denomina de conjunto de matérias (Sachverhalt). Note-se aqui, que já é possível perceber o mecanismo de redução de complexidades sobre o qual se baseia o processo de concretização da Metódica Estruturante, uma vez que se verifica claramente que o conjunto de matérias constitui um nível mais aprofundado de concretização em relação ao relato sobre o caso. ${ }^{94}$

O conjunto de matérias (Sachverhalt) não se confunde com os dados reais préjurídicos, uma vez que, embora sejam todos eles fáticos, i.e., não decorram do trato jurídico com os textos de norma, mas da realidade, o conjunto de matérias, ao contrário dos dados reais iniciais, já está relacionado aos textos da norma, em razão da interferência do conhecimento profissional do jurista. ${ }^{95}$

\footnotetext{
${ }^{91}$ J. M. ADEODATO, Ética e retórica..., op. cit., p. 240.

${ }^{92}$ Em J. M. ADEODATO, Ética e retórica..., op. cit., pp. 240-241: “O relato do caso é a maneira pela qual o caso em questão chega ao conhecimento do profissional do direito: 'essa mulher sempre foi muito apaixonada pelo marido'; 'ela dependia emocional e financeiramente dele'; 'essa mulher se comportava de maneira estranha, assim e assado'; 'essa mulher adora roupas coloridas'; 'ela comprou revólver e balas no dia tal'; 'esse homem comportava-se como se fosse abandoná-la'; 'esse homem levou um tiro no peito'; 'ele tinha muitos amigos e torcia pelo Sport Clube'; e assim por diante."

${ }^{93}$ J. M. ADEODATO, Ética e retórica..., op. cit., pp. 240-241.

${ }^{94}$ J. M. ADEODATO, Ética e retórica..., op. cit., p. 241.

95 Aqui, faz-se necessária uma digressão para não cairmos no erro de tomar como idênticos ao conjunto de matérias, pelo menos na Metódica Estruturante, outros termos tradicionalmente utilizados pela dogmática jurídica, tais como o suporte fático. Com esse objetivo, podemos ver em J. M. ADEODATO, Ética e retórica..., op. cit., pp. 241-244, que "Na linguagem comum da Alemanha de hoje, Sachverhalt e Tatbestand são conceitos, regra geral, usados indistintamente como o fato ou conjunto de fatos. Há também uma confusão com o termo 'âmbito da norma' e mesmo com a expressão 'natureza das coisas'. Na metódica estruturante, porém, o ‘conjunto de matérias' (Sachverhalt) e o 'âmbito da norma' (Normbereich) são conceitos diferentes e não se confundem explicitamente com o conceito de Tatbestand, 'suporte fático' na clássica tradução de Pontes de Miranda. Para Pontes, 'O suporte fático (Tatbestand) da regra jurídica, isto é, aquele fato ou grupo de fatos que o compõe, e sobre o qual a regra jurídica incide, pode ser da mais variada natureza: por exemplo, a) o nascimento do homem, b) o fato físico do mundo inorgânico, c) a doença, d) o ferimento, e) a
} 
Importa, ainda, deixar mais esclarecida uma questão a respeito do Sachverhalt. É que sobre o relato do caso, para se obter o conjunto de matérias, o jurista já utiliza um filtro baseado em sua pré-compreensão, uma vez que interessam a ele apenas alguns aspectos dos fatos relatados, mais propriamente aqueles aspectos que dizem respeito à matéria jurídica. ${ }^{96}$

Outra questão que neste ponto vale ser observada é que o Sachverhalt, ao corresponder ao relato técnico dos fatos, obviamente, decorre dos fatos, de modo que, daqui para frente, ficará mais evidente que a concreção normativa da Metódica Estruturante se processa por fases em que ocorre a interação entre um elemento de concreção que decorre dos fatos, como o Sachverhalt, e outro que decorre dos dados primariamente lingüísticos

entrada em terrenos, f) a passagem por um caminho, g) a goteira do telhado, h) a palavra do orador, i) os movimentos do pastor diante do altar, j) a colheita de frutos, k) a simples queda de fruto'. Já para Müller, 'Essa descrição de relações sociais, tradicionalmente refletidas na doutrina do suporte fático legal (gesetzlichen Tatbestand), não deve ser concebida como descrição coisificada e ontológica, mas sim como parte integrante de complexas técnicas de comunicação’.

Mas a discussão é mais profunda do que essas diferenças e a posição mais simplificada de Pontes parecem fazer crer, e aqui pode-se trazer a contribuição da doutrina italiana, por meio de um conceito muitas vezes identificado com o de Tatbestand. Fattispecie, etimologicamente, vem do latim medieval e significa'figura do fato', consistindo na hipótese que prevê, de forma abstrata e geral, fatos típicos orientados pelas diretrizes de uma valorização jurídica, e que deve ser preferida à expressão fato jurídico, 'porque indica tanto o fato propriamente dito quanto ao mesmo tempo o estado de fato e de direito no qual o fato incide e se enquadra'. Ao entender fattispecie também em uma acepção abstrata, ao lado da concreta, Betti amplia a concepção oferecida por Pontes e já relaciona o mundo dos eventos às abstrações hipotéticas da norma jurídica, aproximando-se do conceito de 'âmbito da norma' que Müller vai sugerir. $\mathrm{O}$ debate insere-se na teoria mais tradicional sobre o fato jurídico e é fruto da Begriffsjurisprudenz, a Escola da 'jurisprudência de conceitos', evoluindo na civilística a partir da discussão sobre noções de direito subjetivo, relação jurídica e situação jurídica. Na doutrina penalística, a teoria do fato jurídico vem acompanhada do conceito de Tatbestand (mais literalmente 'estado de fato'), evidenciando o 'elemento material' do delito e, em sua versão mais restrita, sem incluir o evento, a culpabilidade, nem a antijuridicidade objetiva. Já em seu uso mais amplo, o Tatbestand confunde-se com os conceitos de fato jurídico e de Fattispecie, o 'fato complexo'. Dependendo da concepção de Tatbestand e Fattispecie que se adote, o conceito pode corresponder tanto ao de Sachverhalt quanto ao de Sachbereich da metódica estruturante, ou até ao de Normbereich. Ou seja, Tatbestand é entendido ora como fato, ora como parte da norma, ora como uma inter-relação entre ambos, não havendo a univocidade semântica que Müller parece combater, a qual parece estar melhor exemplificada pela visão mais 'ontológica-realista' de Pontes de Miranda. Ou seja, mesmo em outras definições também mais tradicionais, Tatbestand refere-se à parte da norma que contém as condições para a imputação da conseqüência jurídica. Tentando comparar esse conceito mais abstrato de Tatbestand em Larenz com o de Sachverhalt em Müller, pode-se dizer que, enquanto Tatbestand é a condição fática de incidência da norma, descrita, sugerida no texto mesmo dela, o Sachverhalt é constituído pelos próprios fatos, os acontecimentos reais (Nota de rodapé do autor: 'Evidentemente, do ponto de vista defendido neste livro, insista-se, os eventos reais são intenagíveis, incognoscíveis, referindo-se o termo 'fato' a 'relatos sobre eventos', esse, sim, conteúdos de argumentos jurídicos. Tatbestand, seria o relato feito pelo texto da norma, Sachverhalt seria o relato mais amplo do conjunto de acontecimentos que deverão ser subsumidos ao Tatbestand'), significando que muitas vezes há aspectos do Sachverhalt que permanecem irrelevantes para o Tatbestand e não são ali subsumidos. Um exemplo do Código Penal pode esclarecer: o texto do art. 121, 'matar alguém' é a descrição do Tatbestand, enquanto ' a esposa tal matou, com um tiro no coração, o marido fulano, que a traía no local x com o sujeito y, vestindo tal roupa etc.' é o Sachverhalt. Aí o Tatbestand é 'preenchido' e segue-se a 'conseqüência jurídica' da pena. Mas esse sentido, como visto, não é de modo algum unânime e as expressões por vezes se confundem."

${ }^{96}$ J. M. ADEODATO, Ética e retórica..., op. cit., p. 244. 
originados dos textos de norma e do trabalho jurídico que sobre eles é realizado, como é exemplo o Normtextmenge, de tal maneira que sempre um deles sofrerá uma seleção, um corte, em face do outro, se transformando num terceiro elemento de concreção, de menor complexidade, mais próximo da norma jurídica a ser obtida no final e, portanto, mais impregnado tanto de dados lingüísticos quanto de dados reais.

Seguindo adiante, agora com base no Sachverhalt, no relato técnico dos fatos, o jurista realiza uma seleção do conjunto de textos de norma, obtendo hipóteses normativas de maior correlação com o conjunto de matérias, com os fatos. Tais hipóteses normativas, selecionadas dessa forma, constituem o terceiro elemento de concreção, o chamado âmbito da matéria (Sachbereich). Assim, o Sachbereich resulta da relação entre as hipóteses dos textos específicos escolhidos e o conjunto de matérias formado a partir dos dados reais. ${ }^{97}$

Portanto, para obter o âmbito da matéria (Sachbereich), o jurista observa as características do conjunto de matérias e, com base no seu conhecimento técnico, seleciona os textos de normas válidos. Detalhando mais a atividade do jurista, aqui ele "procura os artigos e parágrafos, os textos que poderiam ser relevantes para o caso que tem diante de si, e ao mesmo tempo observa a realidade, para nela descobrir informações e dados fáticos que poderiam ser significativos. Por exemplo, que para aqueles fatos envolvidos, são relevantes a violenta emoção, o planejamento do homicídio perpetrado, o eventual motivo torpe, a oportunidade ou não de defesa da vítima, em suma, os dados empíricos relevantes à luz dos diversos textos selecionados naquele determinado sistema de textos (não ainda 'normas') válidos. O jurista verifica que, em casos como aquele, são relevantes os artigos tal e tal do ordenamento jurídico, há jurisprudência nesse e nesse sentido, a 'legítima defesa da honra' não é aceita por jurados e juízes, a embriaguez é agravante etc." ${ }^{98}$

Selecionados os textos de normas válidos, passamos agora a mais uma 'seleção de fatos'. Considerando o Sachbereich, os textos de norma selecionados, o jurista seleciona dentre o conjunto de matérias, Sachverhalt, os fatos relevantes, obtendo o chamado 'âmbito do caso' (Fallbereich). É ele, portanto, o próprio conjunto de matérias, Sachverhalt, com sua complexidade reduzida em face da seleção de fatos relevantes com base no âmbito da matéria, Sachbereich. A seleção que se dá na fase do âmbito do caso, pode ser assim exemplificada: "se a fulana homicida estava mesmo enciumada, bêbada, quanto havia bebido, teria sido a ponto de perder a consciência, se maquinou previamente o

\footnotetext{
${ }^{97}$ J. M. ADEODATO, Ética e retórica ..., op. cit., p. 244.

${ }^{98}$ J. M. ADEODATO, Ética e retórica..., op. cit., p. 244.
} 
homicídio, como o fez, com que conversou, em que horários etc.". ${ }^{99}$

Na próxima fase, seguindo a idéia de aproximações sucessivas, procede-se a mais uma seleção de dados lingüísticos, com base na realidade do caso, apurada no último elemento de concretização obtido. Assim, o jurista reúne à interpretação dos textos de norma, já anteriormente especificados na direção daquele caso em questão, a qual já fora denominada de âmbito da matéria, a outros elementos de interpretação, tais como: as teorias, as técnicas hermenêuticas dogmáticas e os demais meios e estratégias de aplicação relevante para o caso em questão, para, enfim, compor o nível de concretização máxima dos dados lingüísticos, o chamado programa da norma (Normprogramm). Portanto, o programa da norma decorre dos dados lingüísticos (Sprachdaten) do caso. ${ }^{100}$

Finalmente, chega-se ao último elemento de concreção ${ }^{101}$, o chamado âmbito da norma (Normbereich). O âmbito da norma é obtido por meio da seleção, mais uma vez, dos fatos normativamente relevantes dentre aqueles que já foram revelados pelo âmbito do caso, com base nos elementos do programa da norma, portanto, com base nos textos da norma interpretados pela ciência e pela práxis jurídicas. Assim, "Diferentemente do âmbito da matéria anterior, o âmbito da norma compreende aquelas características fáticas trazidas ao processo de concretização, a partir do conjunto de matérias e já trabalhadas à luz do programa da norma". ${ }^{102}$

Explica Adeodato que, "No exemplo dado, o jurista observa, em meio aos dados do conjunto de matérias (Sachverhalt), que fulana, enciumada, atirou no marido, mas não se ela cumprimentou o vizinho com palavras ou acenos ou se estava vestida de verde ou de amarelo (a não ser que, no caso, esse elemento venha a ser relevante, na identificação do homicida, por exemplo), ainda que esses dados fáticos façam parte do conjunto de matérias ${ }^{99}$ J. M. ADEODATO, Ética e retórica..., op. cit., p. 245.

${ }^{100}$ J. M. ADEODATO, Ética e retórica..., op. cit., p. 245. Aí também se encontra um aprofundamento sobre o conceito de programa da norma, oferecido pelo autor: "O programa da norma, de nível genérico, sem ligação direta com o caso concreto, cooperará para fornecer o conteúdo da norma, subsidiado pelo conjunto de dados e informações lingüísticos. O programa da norma não é composto somente dos dados lingüísticos relevantes no texto da norma e do ordenamento, tais como os postulados de que os textos constitucionais devem prevalecer sobre os textos do Código Penal ou a importância da estrita legalidade, mas também de textos prévios, como mencionado, tipo anais de discussões legislativas e exposições de motivos (elemento genético), textos de normas anteriores já revogados (elemento histórico), textos doutrinários, técnicas argumentativas etc.”.

${ }^{101}$ Aqui vale uma observação: os elementos de concretização recebem a denominação dada pelo autor e por ele é definida a quantidade de elementos necessários para se chegar, por meio das interações sucessivas, ao nível de menor complexidade e de maior concretização. Contudo, conforme alerta o próprio autor em Ética e retórica..., op. cit., p. 248: "Deve-se insistir que não é em todo caso que se detectam claramente todos esses passos, havendo muitas questões jurídicas que são decididas de forma mais simplificada." Por outro lado, a princípio entendo que também pode haver alguma questão jurídica que, dada sua tamanha complexidade, requeira um maior número de fases de interação e de elementos de concretização.

${ }^{102}$ J. M. ADEODATO, Ética e retórica..., op. cit., p. 246. 
em questão. E sempre tendo em vista o âmbito da matéria (Sachbereich) de que são relevantes certos dados, que ele vai verificar se estão presentes naquele âmbito da norma (Normbereich), tais como motivo torpe, premeditação etc". ${ }^{103}$

$\underline{\mathrm{O}}$ âmbito da norma e o programa da norma compõem a estrutura da norma (Normstruktur). Não devem ser confundidos, ressalte-se. O programa da norma indica os dados lingüísticos (também técnicos) normativamente relevantes, enquanto o âmbito da norma aponta os dados reais normativamente relevantes. O programa da norma serve como mediador dos dados reais e, assim, produz o Normbereich da norma jurídica, isto é, o programa da norma fornece o critério obrigatório para a adequação jurídica da escolha do âmbito da norma a partir do âmbito da matéria e do âmbito do caso. Em outras palavras, o programa da norma limita e faz mediação entre o conjunto de matérias e a construção do âmbito da norma. ${ }^{104}$

O âmbito da norma também se diferencia das peculiaridades do conjunto de matérias por ser uma parte estrutural das próprias prescrições do sistema jurídico, das normas. $^{105}$

Por fim, é importante observar que o âmbito da norma é composto de elementos que podem ser total ou parcialmente produzidos pelo sistema jurídico, ou mesmo de elementos não produzidos por ele. Dos primeiros fazem parte os prazos, procedimentos formais, regras processuais etc., enquanto no rol dos últimos, que se referem a estruturas sociais propriamente ditas, estão honra, família, direitos fundamentais, sociedades comerciais. Quando aparecem exclusivamente elementos produzidos pelo sistema jurídico no caso em questão, por vezes é suficiente a interpretação dos textos de norma, mas isso é relativamente raro, não justificando a tentativa do positivismo legalista de torná-lo regra geral. $^{106}$

${ }^{103}$ J. M. ADEODATO, Ética e retórica..., op. cit., p. 246.

${ }^{104}$ J. M. ADEODATO, Ética e retórica..., op. cit., p. 246.

${ }^{105}$ J. M. ADEODATO, Ética e retórica..., op. cit., p. 247. Aqui, referente à diferença entre âmbito da norma e conjunto de matérias, explica o autor que: "Aplicando praticamente o conceito de âmbito da norma, pode-se dizer que se compõe dos fatos que, diante de um caso a ser resolvido e dos textos da norma a ele correspondentes, à luz de toda experiência jurídica acumulada, precisam ser considerados e não podem ser aleatoriamente escolhidos. Esses fatos não devem permanecer no campo não obrigatório do conjunto de matérias ou do âmbito da matéria; eles não devem contradizer o programa da norma. Os textos das normas referem-se, por exemplo, a partes do mundo real, como 'a imprensa', 'a ciência', 'a arte', 'a concorrência', 'a natureza jurídica do seguro', 'o curso de doutorado'; são esses cortes da realidade social visados pelo programa da norma ou por ele construídos que Müller denomina o âmbito da norma. O âmbito da norma é o juridicamente relevante do conjunto de matérias (Sachverhalt).”.

${ }^{106}$ J. M. ADEODATO, Ética e retórica..., op. cit., p. 247. 


\subsection{A Hierarquia dos Elementos e a Estrutura Jurídica Limitativa}

Assim, entram em jogo na teoria de Müller os seguintes elementos de concretização da norma: "os elementos metodológicos numa acepção estrita (os da interpretação gramatical, histórica, genética, sistemática e 'teleológica', a par de alguns princípios isolados de hermenêutica jurídica), os elementos do âmbito da norma, os elementos dogmáticos, os elementos científicos, da teoria jurídica, os elementos técnicos de solução e os elementos político-jurídicos. Nada obstante, apenas alguns desses elementos se relacionam diretamente com a norma, relacionando-se os demais apenas de forma mediata". ${ }^{107}$

Relacionam-se diretamente com a norma os elementos metodológicos tomados numa acepção estrita, os elementos do âmbito da norma e parte dos elementos dogmáticos. Os demais, que não se relacionam diretamente com a norma, exercem funções limitadas, auxiliares, no processo de concretização. ${ }^{108}$

Em razão disso, constituindo um dos pontos mais complexos e delicados de sua teoria estruturante da norma ${ }^{109}$, Müller intenta estabelecer uma hierarquia entre tais elementos utilizados no processo de concretização, conforme bem explica Bonavides: "Assim é que preceitua teoricamente em caso de conflito, ou seja, de resultados parciais contraditórios, que os elementos imediatamente relacionados com a norma prevaleçam sobre as demais. E se no interior dos elementos imediatamente vinculados à norma se levantar um conflito, entende ainda que a prevalência caberá aos elementos gramaticais e sistemáticos, porquanto eles se referem a interpretação do texto de normas, enquanto os demais a textos que não são textos de normas.". 110

Na mesma linha conclui Christensen: "Portanto, diferentemente da doutrina tradicional, a teoria estruturante do direito está em condições de chegar, em virtude da sua teoria da norma jurídica, a uma hierarquia generalizável dos elementos de concretização. Como dito, no caso de conflito o respectivo argumento mais próximo ao texto da norma terá precedência sobre o argumento mais distante daquele. Isso significa, por exemplo, que no caso de resultados contraditórios dos diferentes elementos de concretização, um elemento metodológico no sentido mais estrito referido ao texto da norma derrota um elemento

\footnotetext{
${ }^{107}$ P. BONAVIDES, Curso..., op. cit., p. 507.

${ }^{108}$ P. BONAVIDES, Curso..., op. cit., p. 507.

${ }^{109}$ P. BONAVIDES, Curso..., op. cit., p. 508.

${ }^{110}$ P. BONAVIDES, Curso..., op. cit., p. 508.
} 
meramente juspolítico ou um elemento dogmático não diretamente referido à norma.” ${ }^{111}$

Neste ponto, revelada uma hierarquia entre os elementos de concretização, importa retomarmos a idéia de uma dialética entre os elementos lingüísticos do programa da norma e os elementos da realidade constituintes da área da norma, aproveitando a explicação oferecida por Canotilho de que a análise de tais elementos não constitui dois processos parciais, separados entre si, dentro do processo de concretização, mas constitui uma análise de processos plena e simultaneamente articulados entre si. $^{1{ }^{12}}$ Isso se dá assim uma vez que o programa da norma tem uma função de filtro relativamente à área da norma, sob um duplo ponto de vista: como limite negativo e como determinante positiva. Esta função de filtro do programa da norma significa ser ele que separa os fatos com efeitos normativos dos fatos que, por extravasarem desse programa, não pertencem à área da norma, perfazendo uma funcionalidade positiva de determinação desses fatos. ${ }^{113}$

Além disso, como o programa da norma é obtido principalmente a partir da interpretação dos dados lingüísticos presentes no texto da norma, daí se deduz o efeito de limite negativo do texto da norma, ou seja, a prevalência sobre os dados da realidade dos elementos de concretização referidos ao texto (gramaticais, sistemáticos ...) no caso de conflito dos vários elementos de interpretação. Conseqüentemente, o espaço de interpretação, ou melhor, o âmbito de liberdade de interpretação do aplicador-concretizador das normas constitucionais ou infraconstitucionais, tem também o texto da norma como limite, de modo que somente os programas normativos que se consideram compatíveis com o texto da norma podem ser admitidos como resultados aceitáveis. ${ }^{114}$

Diante disso, observa Bonavides que: "Como se vê, é ingente e engenhoso o esforço construtivo e analítico do constitucionalista alemão para estabelecer sobre as bases do chamado concretismo uma teoria da estrutura da normatividade constitucional, fazendo que a eficácia da norma, que não está confinada a um texto de lei, e se alarga a espaços materiais e fáticos de máxima amplitude, seja, contudo, reconhecida em moldes jurídicos e presa a esses moldes, conforme decorre da hierarquia acima estabelecida, dos elementos

\footnotetext{
${ }^{111}$ R. CHRISTENSEN, Teoria Estruturante do Direito, trad. port. de R. M. dos Santos, in O Novo Paradigma do Direito - Introdução à teoria e metódica estruturantes do direito, São Paulo, Revista dos Tribunais, 2007, p. 243.

112 J. J. G. CANOTILHO, Direito Constitucional e Teoria da Constituição, 7. ed., Coimbra, Almedina, 2008, p. 1.220 .

${ }^{113}$ J. J. G. CANOTILHO, Direito Constitucional..., op. cit., p. 1.220.

${ }^{114}$ J. J. G. CANOTILHO, Direito Constitucional..., op. cit., p. 1.220.
} 
intervenientes na operação interpretativa.". ${ }^{115}$

E mais, continua ele dizendo que: "Depois de abrir-se amplamente para a realidade, o concretismo de Müller tem sua última postulação assentada numa estrutura jurídica limitativa, decorrente da hierarquia dos elementos hermenêuticos empregados para definir a normatividade e que se descriminam, na sua prevalência, de um modo estimativo, mais técnico do que axiológico ou ideológico. Nisso talvez esteja o ponto vulnerável de sua metodologia, o flanco que ele deixou desguarnecido e por onde a crítica poderá ingressar para demolir todo o edifício engenhosamente erguido.". ${ }^{116}$

\subsection{Norma, Normatividade e Validade}

Com ares de síntese, podemos dizer que: os textos da norma genéricos, relacionados com os relatos genéricos, leigo e profissional, sobre os dados reais, constituídos a partir dos dados lingüísticos primários, conduzem à escolha do âmbito da matéria, o qual é especificado na direção do âmbito do caso. O âmbito do caso é orientado pelos padrões do programa da norma e, juntos, constituem o âmbito da norma. O programa da norma e o âmbito da norma vão por sua vez formar a norma jurídica, a qual se concretizará na norma decisória. ${ }^{117}$

Assim, o processo de concretização, iniciado com a mediação do conteúdo dos enunciados lingüísticos do programa da norma e com a seleção dos dados reais constitutivos do universo exterior abrangidos pelo programa da norma, conduz-nos a uma primeira idéia de norma jurídica, modelo de ordenação material prescrito pela ordem jurídica como vinculativo e constituído de: uma medida de ordenação linguisticamente formulada (ou captada por meio de dados lingüísticos); e, um conjunto de dados reais selecionados pelo programa da norma (a área da norma). ${ }^{118}$

Por intermédio desses conceitos, pela ordem, Sprachdaten, Realdaten, Normtexte, Fallerzählung, Sachverhalt, Sachbereich, Fallbereich, Normprogramm, Normbereich, Rechtsnorm e Entscheidungsnorm, Müller quer detalhar e subdividir em passos o processo do 'trabalho jurídico' (Rechtsarbeit), o tratamento que o jurista dá ao caso concreto, já

\footnotetext{
${ }^{115}$ P. BONAVIDES, Curso..., op. cit., p. 508.

${ }^{116}$ P. BONAVIDES, Curso..., op. cit., p. 509.

${ }^{117}$ J. M. ADEODATO, Ética e retórica..., op. cit., p. 248.

${ }^{118}$ J. J. G. CANOTILHO, Direito Constitucional..., op. cit., p. 1.221.
} 
abandonando a oposição abstrata entre fato e norma. ${ }^{119}$

No contexto da concretização, todos os procedimentos e elementos anteriores, quais sejam os dados lingüísticos, os dados reais, os textos da norma, o relato do caso, o conjunto de matérias, o âmbito da matéria, o âmbito do caso, o programa da norma e o âmbito da norma, constituem dados de entrada (Eingangsdaten) e não têm caráter normativo. A normatividade só aparece nos resultados da concretização, vale dizer, na norma jurídica (Rechtsnorm), como resultado intermediário, e na norma decisória (Entscheidungsnorm), o resultado final. ${ }^{120}$

A Rechtsnorm é exatamente o somatório do programa da norma e do âmbito da norma. Por outro lado, a Entscheidungsnorm é o teor da decisão, "por exemplo: o acusado foi declarado inocente e liberado; o réu deve pagar dez mil reais ao autor; o pai ficará com o filho nos dias de quinta-feira a sábado; e assim por diante. Essa norma decisória é o resultado final de todas as fases anteriores do trabalho jurídico de concretização". ${ }^{121}$

Agora podemos perceber melhor o que já foi antecipado em seções anteriores, que a teoria jurídica estruturante de Müller e a metódica jurídica a partir dela construída desenvolvem a diferença entre a validade do texto normativo e a normatividade da norma jurídica, ou seja, o texto da norma, no começo do 'trabalho com textos juridicos' (Rechtstext und Textarbeit), não tem ainda significado normativo, mas apenas validade. Essa validade significa que os destinatários do texto devem se conduzir de forma compatível com ele, não só os leigos, mas também os profissionais e o juiz, com a obrigação de considerá-lo dado de entrada da concretização e trabalhá-lo de modo metodicamente correto. Mas só no caso concreto aparece o caráter normativo, a norma jurídica. ${ }^{122}$

Nada obstante, como já dito em seção anterior, a metódica estruturante mantém o conceito positivista de validade, ainda que do texto e não da norma jurídica, entendendo-o como a propriedade de determinado objeto estar de acordo com as regras do sistema jurídico quanto a conteúdo, competência e rito de elaboração. Para Müller, assim

\footnotetext{
${ }^{119}$ J. M. ADEODATO, Ética e retórica..., op. cit., p. 248. Aí, mais uma vez encontra-se a observação feita pelo autor de que não seria em todo caso que se detectam claramente todos esses passos, havendo muitas questões jurídicas que são decididas de forma mais simplificada. Também aí se encontra uma interessante observação feita pelo autor, em nota de rodapé, que aqui reproduzo apenas como uma provocação sobre a questão terminológica da teoria estruturante: "É curioso que, embora divida o trabalho para tratamento do caso jurídico em fases subseqüentes no tempo, as quais levam a resultados parciais que se vão integrando, Müller utilize três expressões compostas pelo termo primordialmente espacial Bereich.".

${ }^{120}$ J. M. ADEODATO, Ética e retórica..., op. cit., p. 248.

${ }^{121}$ J. M. ADEODATO, Ética e retórica..., op. cit., p. 248.

${ }^{122}$ J. M. ADEODATO, Ética e retórica..., op. cit., p. 249.
} 
como para o positivismo jurídico, não há no termo o conteúdo axiológico que lhe empresta, por exemplo, a teoria do discurso, para a qual a validade tem a ver com racionalidade, adequação, correção. ${ }^{123}$

\subsection{Críticas ao Modelo e sua Compilação}

Até aqui, apresentamos a parte mais substancial do presente trabalho: o referencial metodológico adotado para análise de argumentos utilizados na jurisprudência do Supremo Tribunal Federal. Porém, antes de passarmos ao capítulo final, em que se pretende testar a correspondência da metódica com a jurisprudência e, por outro lado, entender o quão estruturada é essa jurisprudência à luz da metódica, importa ainda, neste capítulo: a) prezando pela honestidade na pesquisa, apresentarmos valorosas críticas à Metódica Estruturante, proferidas por autores como Andrade, Neves e Adeodato, já exaustivamente mencionados neste trabalho, de modo a não incorrermos no erro de se assumir como perfeita e acabada uma teoria que, apesar de estar aí há décadas, encontra-se ainda em pleno processo de assimilação no direito pátrio; e, por fim, b) realizarmos um esforço de compilação dos elementos da metodologia de hermenêutica jurídica aqui vista.

\subsubsection{Esboço de Uma Crítica}

Uma primeira questão diz respeito à crítica oferecida por José Maria A. de Andrade em face de sua constatação de que a concepção desenvolvida por Friedrich Müller deixa de se comprometer ${ }^{124}$ com o não-representacionalismo propugnado nos construtos de segunda fase de Wittgenstein, de modo que, Andrade deixa claro em seus trabalhos que embora se utilize de todo o instrumental da metódica jurídica estruturante, mantém ainda o filtro teórico das investigações wittgensteinianas e, sempre que compatível, de outros construtos anti-representacionalistas, como o neopragmatismo norte-americano e a teoria biológica do conhecimento ${ }^{125}$.

Vale ressaltar, tal objeção não configura qualquer limitação ao presente trabalho uma vez que o objetivo aqui proposto é simplesmente a verificação da conformidade da

\footnotetext{
${ }^{123}$ J. M. ADEODATO, Ética e retórica..., op. cit., pp. 249-250.

${ }^{124}$ J. M. A. DE ANDRADE, Interpretação..., op. cit., pp. 156-157.

${ }^{125}$ J. M. A. DE ANDRADE, Interpretação..., op. cit., p. 161.
} 
metódica retirada da teoria de Müller com a prática jurisprudencial pátria, portanto, algo muito distante de uma busca por justificações dos fundamentos dessa teoria.

Marcelo Neves afirma que a Teoria Estruturante concebida Müller, embora se mantenha em uma perspectiva semântico-pragmática do processo interpretativo, portanto não escapando da dimensão semântica, consegue impingir uma maior relevância ao aspecto pragmático da interpretação que a tradição hermenêutica, até Gadamer, jamais conseguiu. ${ }^{126}$

Porém, embora a abordagem estruturante do processo de concretização não reduza a relevância da dimensão pragmática da interpretação, enfatizando o papel ativo e criador do intérprete ao executar o trabalho jurídico, tem ainda o seu método excessivamente lastreado na semântica, deixando de enfrentar satisfatoriamente muitas questões de ordem jurídico-pragmática. ${ }^{127}$

Isso ocorre em especial, conforme explica Marcelo Neves, "quando se sustenta que a decisão concretizante, embora possa apresentar conteúdos os mais variáveis, tem de ser justificada com argumentos objetivos (Sachargumenten) que sejam 'atribuíveis (Zurechenbar) aos textos normativos do Direito vigente'. Assim sendo, trata-se, na interpretação, de determinar os limites textuais das concretizações juridicamente corretas. Mas qual o critério semântico para definir, dentre as concretizações possíveis - mesmo dando-se relevância aos outros elementos lingüísticos do programa da norma e aos dados reais da área da norma aquelas que são compatíveis com o texto? Evidentemente, tal questão, embora tenha parâmetros semânticos, só pode ser discutida satisfatoriamente no plano pragmático". ${ }^{128}$

E, continua ele, "todos os problemas referentes à determinação das interpretações ou concretizações juridicamente corretas são, antes de tudo e eminentemente, pragmáticos, tendo em vista a relação discursivo-dialógica entre intérpretes, sejam estes agentes ou destinatários da decisão conseqüente, e a multiplicidade de expectativas que se contradizem e conflitam com relação ao texto da norma". ${ }^{129}$

Quanto a essas críticas, vale também a observação de que não constituem elas qualquer objeção ao presente trabalho, uma vez que aqui não se pretende buscar justificações pelos fundamentos teóricos da metódica nem se ocupar com preocupações que envolvam aspectos da semiótica jurídica.

\footnotetext{
${ }^{126}$ MARCELO NEVES, A Interpretação Jurídica no Estado Democrático de Direito, in Direito Constitucional Estudos em homenagem a Paulo Bonavides, São Paulo, Malheiros, 2003, p. 360.

${ }^{127}$ MARCELO NEVES, A Interpretação Jurídica..., p. 362.

${ }^{128}$ MARCELO NEVES, A Interpretação Jurídica..., p. 362.

${ }^{129}$ MARCELO NEVES, A Interpretação Jurídica..., p. 362.
} 
Por outro lado, inserida no contexto das novas metodologias hermenêuticas pragmáticas, o sistema concebido por Müller, intencionalmente seguro por amarras no plano mesmo semântico, tenta não sucumbir a um alargamento excessivo do âmbito possível de interpretação. Esse alargamento extremo, nas palavras de Bonavides, "que faz de todos, no pluralismo democrático da sociedade aberta, a um tempo objeto e sujeito da ordem constitucional, se de uma parte representa a verticalidade da reflexão que vai atingir camadas mais profundas não alcançadas pela metodologia clássica, doutra parte pode conduzir, pela sua radicalização, a um considerável afrouxamento da normatividade e juridicidade das Constituições, como tem sido observado e criticado com respeito a todos os métodos tópicos e concretistas". 130

Adeodato, ao dissertar sobre a Metódica Estruturante, produz interessantes observações, afirmando que Friedrich Müller “tem papel importante na crítica à teoria da interpretação dominante, de vertente mais positivista, que limita as 'formas de interpretação quanto ao método' aos métodos gramático, lógico, histórico, sistemático, tentando uma perspectiva hermenêutica mais realista e evitando a concepção mais simplista de que interpretar é determinar 'o sentido e o alcance da norma diante do caso', inadequada às sociedades complexas contemporâneas". ${ }^{131}$

Uma primeira observação por ele oferecida à crítica da Metódica Estruturante é a de que, “embora seja certo que a norma geral só se torna aplicável quando 'transformada' em decisão do caso concreto, ou seja, 'definida', 'concretizada', o problema é que, para essa junção de texto com realidade, 'concretização', um ponto de orientação específico não é fornecido nem requerido. Permanece indefinido, na teoria de Müller, em que medida seu método supre as deficiências de uma tópica como a de Viehweg, acusada de casuística, ou da 'Constituição Aberta' de Peter Häberle, que têm uma perspectiva mais pragmática do que semântica e enfatizam o papel dos operadores jurídicos e demais agentes envolvidos na decisão do conflito, com pretensões mais modestas de objetividade". ${ }^{132}$

Nessa mesma linha, outra questão, que é de ser notada, constitui o fato de que pode haver em casos particulares enorme dificuldade em se determinar claramente as fases do procedimento de concretização normativa propugnado pela Metódica Estruturante. Isso ocorre, por exemplo, quando o STF aprecia inconstitucionalidade em abstrato na ação direta,

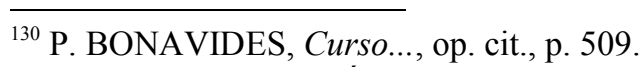

${ }^{131}$ J. M. ADEODATO, Ética e retórica..., op. cit., p. 250.

${ }^{132}$ J. M. ADEODATO, Ética e retórica..., op. cit., p. 251.
} 
situação em que se torna bastante difícil definir o âmbito do caso, e outros elementos de concretização, uma vez que obviamente não há propriamente um caso concreto, mas há tão somente uma análise de tese jurídica. ${ }^{133}$

Tal objeção não é inteiramente procedente uma vez que, mesmo quando é apreciada suposta inconstitucionalidade em ação direta, sempre existem elementos fáticos, que não são provenientes de um caso concreto determinado, mas do contexto fático que envolve a problemática e que assumem, ou deveriam assumir conforme a teoria de Müller, capital importância na análise da tese jurídica. Assim, mesmo na Ação Direita de Inconstitucionalidade, no modelo mülleriano, haverá o processo de concreção que é pressuposto da existência da norma jurídica, geral e abstrata.

Outra observação importante, bem percebida por Adeodato, é a de que "discutir com Müller se torna muito complicado, por causa de sua originalidade conceitual. Nunca se sabe se conceitos corriqueiros como normatividade, âmbito da norma, estrutura da norma e outros estão sendo propriamente entendidos". ${ }^{134}$

De fato, a observação acima, longe de se constituir uma objeção, aponta efetivamente para uma dificuldade a ser enfrentada no presente trabalho. Além disso, some-se a ela o fato de que a bibliografia de Müller apresenta poucos, quase nenhum, exemplos de aplicação.

Outra observação, agora de caráter mais geral, refere-se ao fato de que a teoria estruturante acaba por se concentrar predominantemente na figura da autoridade estatal judicante. Tal perspectiva parte de dois pressupostos, o primeiro diz respeito ao fato de ser o direito visto, sobretudo, a partir do conflito e da necessidade de seu controle; o segundo diz respeito ao fato de o direito efetivamente apresentar-se concretizado, na maioria dos casos, por meio da atividade judicante. ${ }^{135}$

Nada obstante, pode-se perfeitamente sustentar que todos os destinatários das normas jurídicas são responsáveis pela sua concretização e efetivamente as constroem. Não só isso, é perfeitamente possível sustentar, na linha defendida por Häberle, em que não se pode estabelecer um numerus clausus de intérpretes da Constituição, que todo o ambiente social, de forma plural, determina o sentido das normas jurídicas e, portanto, as concretiza. Diante dessas possibilidades, Müller acabou ampliando seu conceito de

\footnotetext{
${ }^{133}$ J. M. ADEODATO, Ética e retórica..., op. cit., pp. 252-253.

${ }^{134}$ J. M. ADEODATO, Ética e retórica..., op. cit., p. 253.

${ }^{135}$ J. M. ADEODATO, Ética e retórica..., op. cit., p. 254.
} 
concretização para abarcar outros tipos de intérpretes, mantendo, todavia, o enfoque na atividade profissional do jurista, até porque foi dela que, de forma indutiva, construiu sua teoria. $^{136}$

Outra crítica à preponderância da atividade judicante na concretização, em especial em face de ter sido a teoria construída sobre os trabalhos das cortes constitucionais supremas, encara tal fato como uma realidade prejudicial ao Estado democrático de direito, pois o Judiciário passa a ser o guardião do conteúdo moral do direito. Assim, em pleno antagonismo às teorias que pretendem ver a moral como limitadora do direito, como se dá na concepção de Ronald Dworkin, a teoria estruturante, ao colocar o juiz como intérprete maior, insere uma espécie de 'moral do judiciário' nas questões jurídicas, podendo não limitar, ou até ampliar de modo preocupante, as fronteiras do que é jurídico e coercitivo. ${ }^{137}$

Por outro lado, continuando essa linha argumentativa, não é dada a devida importância ao fato de que, na maioria dos casos, as relações jurídicas são concretizadas consensualmente, longe dos conflitos e dos tribunais, sem necessidade da coerção estatal. Contudo, mesmo nos ditos Estados Democráticos de Direito nem toda concretização do direito se dá a partir de lides. ${ }^{138}$

Quanto a essas objeções, relativas ao excessivo papel do juiz na teoria de Müller, vale observar que não representam elas qualquer prejuízo à análise que aqui se pretende fazer pela singela razão de que é justamente o trabalho desses atores que nos interessa.

Uma última ponderação, que vale ressaltar aqui, constitui a de que parece haver na Metódica Estruturante uma identificação entre os textos normativos e a lei. Isso pode decorrer da inserção de seu autor no contexto do sistema romano-germânico de direito legislado. Embora as sociedades modernas, dada a sua complexidade, não possam prescindir do direito legislado, baseando-se primordialmente nos costumes jurídicos, há certamente inúmeras situações em que se opera o direito mediante textos jurisprudenciais, como as sentenças, os acórdãos, as súmulas, ou mesmo os precedentes judiciários não-vinculantes, como se observa em especial nos países da commom law. ${ }^{139}$

Nada obstante, essa questão, acima apontada, não se aplica ao caso do presente trabalho já que o direito brasileiro também se insere no sistema romanogermânico, recebido por herança de Portugal.

\footnotetext{
${ }^{136}$ J. M. ADEODATO, Ética e retórica..., op. cit., p. 254.

${ }^{137}$ J. M. ADEODATO, Ética e retórica..., op. cit., p. 255.

${ }^{138}$ J. M. ADEODATO, Ética e retórica..., op. cit., pp. 255-256.

${ }^{139}$ J. M. ADEODATO, Ética e retórica..., op. cit., p. 257.
} 


\subsubsection{Esforço de Compilação}

A Teoria Estruturante do Direito surgiu no contexto da experiência constitucional alemã, como uma proposta metodológica construída a partir da observação da jurisprudência firmada e não como a construção de um sistema meramente teórico. Assim, partiu-se da análise dos trabalhos dos operadores do direito, observados quando do funcionamento do ordenamento jurídico, e não de sistemas filosóficos para, posteriormente, analisar a jurisprudência alemã. ${ }^{140}$

Em decorrência disso, do caráter indutivo de sua teoria, Müller declara a sua adesão a apenas algumas ideias e não aos sistemas filosóficos concebidos por Wittgenstein, Heidegger e Gadamer. ${ }^{141}$

De fato, como assevera José Maria A. de Andrade ${ }^{142}$, ao elaborar o seu ferramental metodológico, Friedrich Müller não assume decididamente uma pauta não representacionalista para a hermenêutica jurídica e, nesse aspecto, afasta-se de um maior comprometimento com o referencial wittgensteiniano.

Prosseguindo, podemos então dizer que o enfoque mülleriano parte do entendimento de que o direito é conhecido e mediado pela linguagem e a realidade, assim como o texto normativo, é dado constitutivo da norma jurídica, que somente pode ser obtida quando de sua aplicação no processo de concreção.

Sua hermenêutica rejeita concepções, presentes nas escolas tradicionais, de identificação entre norma e texto, de identificação entre texto e objeto significado, assim como da interpretação como mera atribuição de sentido aos textos de lei sem, contudo, considerar as particularidades do caso concreto em face das circunstâncias que o cercam.

Com base nessa perspectiva, podemos sintetizar os elementos de concretização concebidos pela Metódica Estruturante, conforme as tabelas I e II, a seguir:

Tabela I: Dados pré-jurídicos do modelo

\footnotetext{
${ }^{140}$ J. M. A. DE ANDRADE, Interpretação..., op. cit., pp. 156-157.

${ }^{141}$ J. M. A. DE ANDRADE, Interpretação..., op. cit., pp. 156-157.

${ }^{142}$ Interpretação..., op. cit., p. 157.
} 


\begin{tabular}{|l|l|l|}
\hline $\begin{array}{l}\text { Elemento de } \\
\text { concretização }\end{array}$ & Eonceito & Exemplo \\
\hline Dados Lingüísticos & $\begin{array}{l}\text { Sprachdaten } \\
\text { Pontos de vista interpretativos } \\
\text { comuns (gramáticos, sistemáticos e } \\
\text { genéticos). }\end{array}$ & $\begin{array}{l}\text { 'para' é proposição; art, 14, §1 } 1^{\circ}, \mathrm{II}, \mathrm{b}, \mathrm{da} \\
\text { Constituição Federal: "o voto dos maiores de 70 } \\
\text { anos é facultativo" - 'facultativo' e 'obrigatório' } \\
\text { têm sentidos diferentes na língua portuguesa }\end{array}$ \\
\hline Dados Reais & $\begin{array}{l}\text { Realdaten } \\
\text { Elementos naturais e sociais, que } \\
\text { não são primariamente formados } \\
\text { pela linguagem, mas são } \\
\text { necessariamente intermediados } \\
\text { por ela }\end{array}$ & $\begin{array}{l}\text { dois corpos não ocupam o mesmo lugar no espaço; } \\
\text { uma faca é capaz de penetrar em um corpo } \\
\text { humano, a depender das condições; as diferenças } \\
\text { entre um ato de compra e venda e um de aluguel ou } \\
\text { entre uma sociedade limitada ou por ações }\end{array}$ \\
\hline
\end{tabular}

Tabela II: Elementos jurídicos do modelo

\begin{tabular}{|c|c|c|}
\hline $\begin{array}{l}\text { Elemento de } \\
\text { concretização }\end{array}$ & Conceito & Exemplo \\
\hline $\begin{array}{l}\text { Conjunto de textos de } \\
\text { norma }\end{array}$ & \begin{tabular}{|l} 
Normtextmenge \\
Textos do ordenamento jurídico cujo \\
sentido básico é contextualizado pelos \\
dados reais e lingüísticos comuns (dados \\
pré-jurídicos), vinculados àquela \\
determinada estrutura social.
\end{tabular} & $\begin{array}{l}\text { Textos de leis, de processos, de acórdãos, } \\
\text { de sentenças. Respeitam as regras de } \\
\text { inteligibilidade da língua em que são } \\
\text { escritos. }\end{array}$ \\
\hline Relato sobre o caso & $\begin{array}{l}\text { Fallerzählung } \\
\text { Relato não profissional por meio do qual } \\
\text { o caso em questão chega ao conhecimento } \\
\text { do profissional do direito. }\end{array}$ & $\begin{array}{l}\text { 'Essa mulher sempre foi muito apaixonada } \\
\text { pelo marido'; 'ela dependia emocional e } \\
\text { financeiramente dele'; 'ela comprou } \\
\text { revólver e balas no dia tal'; 'esse homem } \\
\text { comportava-se como se fosse abandoná-la'; } \\
\text { 'esse homem é torcedor do Sport' e 'levou } \\
\text { um tiro no peito' }\end{array}$ \\
\hline Conjunto de matérias & $\begin{array}{l}\text { Sachverhalt } \\
\text { É obtido quando o profissional do direito, } \\
\text { mediante sua pré-compreensão, passa o } \\
\text { 'relato sobre o caso' por um filtro técnico. }\end{array}$ & $\begin{array}{l}\text { São os fatos, já selecionados pela pré- } \\
\text { compreensão do jurista. No exemplo } \\
\text { anterior, o jurista poderia selecionar os fatos } \\
\text { excluindo o relato de que 'esse homem é } \\
\text { torcedor do Sport' }\end{array}$ \\
\hline Âmbito da matéria & $\begin{array}{l}\text { Sachbereich } \\
\text { São as hipóteses normativas específicas } \\
\text { escolhidas do 'conjunto de textos de } \\
\text { norma' com base nas características do } \\
\text { 'conjunto de matérias' }\end{array}$ & $\begin{array}{l}\text { Jurista procura artigos e parágrafos que } \\
\text { poderiam ser relevantes para o caso. Poderia } \\
\text { o jurista descobrir que para aqueles fatos } \\
\text { envolvidos são relevantes a violenta } \\
\text { emoção, o planejamento do homicídio, o } \\
\text { eventual motivo torpe }\end{array}$ \\
\hline Ấmbito do caso & \begin{tabular}{|l} 
Fallbereich \\
São fatos relevantes selecionados do \\
'conjunto de matérias' com base nas \\
características do 'âmbito da matéria'
\end{tabular} & $\begin{array}{l}\text { Se a fulana homicida estava mesmo } \\
\text { enciumada, bêbada, quanto havia bebido, } \\
\text { teria sido a ponto de perder a consciência, se } \\
\text { maquinou previamente o homicídio, como o } \\
\text { fez, com que conversou, em que horários } \\
\text { etc. }\end{array}$ \\
\hline
\end{tabular}




\begin{tabular}{|l|l|l|}
\hline Programa da norma & $\begin{array}{l}\text { Normprogramm } \\
\text { Dados lingüísticos normativamente } \\
\text { relevantes; obtidos pelo jurista a partir do } \\
\text { 'âmbito da matéria', com base nas } \\
\text { características do ‘âmbito do caso', } \\
\text { utilizando teorias e técnicas } \\
\text { hermenêuticas. }\end{array}$ & $\begin{array}{l}\text { Todas as interpretações do 'conjunto de } \\
\text { textos de norma' já anteriormente } \\
\text { especificado na direção do caso em questão } \\
\text { (é o próprio ‘âmbito da matéria') reunidas às } \\
\text { teorias, técnicas hermenêuticas dogmáticas e } \\
\text { demais meios e estratégias que o jurista } \\
\text { considera aplicáveis naquele momento }\end{array}$ \\
\hline $\begin{array}{l}\text { Âmbito da norma } \\
\text { Normbereich } \\
\text { Dados reais normativamente relevantes, } \\
\text { escolhidos a partir do 'âmbito da matéria' } \\
\text { e do ‘âmbito do caso', unindo os textos da } \\
\text { norma aos dados lingüísticos específicos } \\
\text { do 'programa da norma' a ele conectados } \\
\text { pela ciência e pela práxis jurídicas. }\end{array}$ & $\begin{array}{l}\text { Partes do mundo real referidas pelo } \\
\text { 'conjunto textos de norma' tais como: 'a } \\
\text { imprensa', 'a ciência', 'a arte', 'a } \\
\text { concorrência', 'a natureza jurídica do } \\
\text { seguro', 'o curso de doutorado', ou seja, são } \\
\text { cortes da realidade social visados pelo } \\
\text { spograma da norma' ou por ele construídos } \\
\text { tais como prazos, regras processuais ...) }\end{array}$ \\
\hline
\end{tabular}

Os dois últimos elementos da tabela II, o 'âmbito da norma' e o 'programa da norma', por sua vez, vão compor a 'estrutura da norma' (Normstruktur), ou seja, a própria norma jurídica (Rechtsnorm) que se concretizará na norma decisória (Entscheidungsnorm).

Vale lembrar que esses elementos não significam um encadeamento sucessivo de modo a haver uma sequência definida de análise. Podem algumas fases ocorrer simultaneamente, porém, deve-se ater ao encadeamento lógico aplicável ao caso em análise. $\mathrm{Na}$ realidade, como já explicado na seção 2.5., ocorre uma redução progressiva de complexidades à medida que o trabalho jurídico se desenvolve.

Assim, grosso modo, o primeiro elemento jurídico propriamente dito, o 'conjunto de textos de norma' são textos de norma obtidos dos chamados dados pré-jurídicos (dados lingüísticos e dados reais), promovendo uma primeira redução de complexidade do caso decidendo; o segundo, relatos dos fatos; o terceiro, relatos técnicos dos fatos, já reduzindo mais ainda a complexidade; o quarto, são hipóteses normativas escolhidas do 'conjunto de textos de norma' com base nos relatos técnicos dos fatos, de modo a reduzir o número de hipóteses normativas, reduzindo complexidade mais ainda; o quinto, são hipóteses fáticas presentes no 'conjunto de matérias' (relato técnico dos fatos) que são escolhidas com base no 'âmbito da matéria' (hipóteses normativas), reduzindo mais ainda a complexidade do caso, e assim por diante, como que numa dialética espiral convergente para, selecionando e excluindo hipóteses, reduzir a complexidade inicial do universo de elementos envolvidos no caso até a solução relevante, precisa, coerente, consubstanciada no binômio norma jurídica/norma decisão. 
Portanto, a Metódica Estruturante corresponde à construção de uma estrutura dinâmica, que se opera por um processo de seleção de elementos correlatos, escolhendo aqueles que são relevantes com base em elementos obtidos na etapa antecedente desse processo, ora de ordem fática, ora de ordem texto-normativa. Essa estrutura dinâmica tem como ponto de equilíbrio aquele correspondente ao par ordenado [programa da norma , área da norma]. A identidade da Metódica é, assim, definida pelo rol de elementos de concreção ao lado dessa estrutura dinâmica. 


\section{ANÁLISE DE DECISÕES NO ÂMBITO DO STF}

\subsection{Contornos de Análise}

Antes de prosseguirmos com o estudo proposto nas linhas iniciais, quando dizíamos que o objetivo aqui constitui a análise da estruturação argumentativa das decisões emanadas do órgão de proteção constitucional brasileiro, à luz de uma teoria estruturante como a erigida pelo eminente mestre alemão, Friedrich Müller, importa, no presente subcapítulo, estabelecermos, de forma mais rigorosa, os contornos limitativos dessa análise.

Primeiramente, é de se dizer que o presente trabalho se desenvolve sobre o enfoque da interpretação realizada pelos 'intérpretes autênticos' kelsenianos, ou melhor, na concepção de Müller, pelos 'trabalhadores jurídicos', de modo que a discussão levantada por Eros Grau, referente à interpretação promovida pelos demais operadores do direito, não é abordada por extrapolar os objetivos aqui propostos. ${ }^{143}$

Por outro lado, é importante asseverar que não se pretende, com o presente trabalho, descobrir o quanto o juiz conhece a respeito da teoria de Friedrich Müller, ou seja, não é uma avaliação da erudição ou do conhecimento jurídico do magistrado, muito pelo contrário, pretende-se tão somente descobrir se ele utiliza no trabalho de julgamento um padrão de organização como o da Metódica Estruturante.

Quanto ao trabalho de julgamento, embora Müller se refira em boa parte de sua bibliografia ao pensamento dos trabalhadores jurídicos, firma-se como contorno de análise que não estamos acessando o pensamento propriamente, porque este, pelo menos diretamente, é inacessível.

Portanto, como a presente análise se dará sobre os textos produzidos nos julgamentos, ou, de outra forma, sobre os textos dos acórdãos, e documentos a eles anexos, proferidos pelo Supremo Tribunal Federal, melhor seria entendermos que essa análise avalia a estrutura discursiva que deles transparece.

De fato, a análise feita por Müller tem como substrato as decisões proferidas pela Corte Constitucional alemã, acessando através delas tão somente o seu discurso fundamentador.

Assumir tal hipótese não implica a mutilação da teoria uma vez que o exercício de

143 GRAU, E. R., Ensaio e discurso sobre a interpretação/aplicação do direito, 4.ed., São Paulo, Malheiros Editores, 2006, pp. 66-67. 
aplicação da metódica independe dessa definição, ou, melhor dizendo, poderia ser realizado, sem qualquer prejuízo, tanto na hipótese de o objeto acessado ser a própria estrutura do pensamento ou apenas a estrutura discursiva do intérprete.

Porém, assume-se aqui, por simplicidade, que o objeto de análise acessado é tão somente a argumentação jurídica presente nas decisões.

Assim, o objeto de trabalho da análise é a argumentação jurídica e a pergunta que se faz é, por um lado, em que medida a metódica estruturante descreve a organização argumentativa das decisões do STF e, de outro lado, em que medida apresenta-se estruturada a argumentação jurídica das decisões do STF à luz da metódica.

Vale dizer, caso verificada a hipótese de não conformidade entre a metódica e a prática, tal fato não implicaria, necessariamente, por um lado, uma suposta imprestabilidade do modelo erigido por Müller, nem, por outro lado, um atestado de desestruturação argumentativa da jurisprudência do Supremo. De fato, nessa hipótese, poder-se-ia inferir, tão somente, que as decisões emanadas pelo STF, na amostra analisada, não seguem um padrão de estruturação como aquele da Metódica Estruturante, podendo seguir, porém, um outro padrão de estruturação, cuja identificação não faz parte, precipuamente, do objeto do presente trabalho.

Também, a hipótese acima levantanda, de não conformidade, não implicaria uma avaliação da "qualidade" de aderência da Metódica Estruturante ao modo como a realidade se comporta. Um motivo claro para isso decorre do fato de que o presente estudo se concentra sobre uma amostra bastante específica, tomada da jurisprudência brasileira, ao passo que em momento algum pretendemos atribuir uma generalidade ao modelo mülleriano pela simples razão de que a demonstração de tal característica fugiria em muito ao escopo do trabalho.

Por fim, quanto a isso, a Metódica Estrurante, a despeito de um possível resultado de não conformidade, pode ser muito bem ser tomada como um modelo teórico de referência, como um ideal de hermenêutica, ou de estruturação argumentativa, a ser perseguido, do que daí já extrairia enorme prestabilidade à ciência do direito.

Nada obstante, sugere-se para um outro trabalho, porque foge ao escopo do presente, a busca de respostas à pergunta a respeito de como a metódica poderia ser utilizada para reformatar argumentos jurídicos utilizados nas decisões, ou, até mesmo, selecionar argumentos bons ou ruins, o que levaria, inevitavelmente, à discussão a respeito da difícil questão da hierarquia entre os elementos de concreção. Porém, em razão da necessidade de se 
limitar o escopo do presente trabalho, optamos por excluir tais questionamentos.

Ainda a respeito da questão precedente, por fim, avaliar a estrutura argumentativa de decisões com base na Metódica Estruturante é, por outro lado, verificar os limites dessa teoria, o que poderia conduzir à discussão a respeito da condição de ser ou não essa metódica uma teoria retórica. Porém, pelos mesmos motivos acima já expostos, optamos por deixar essa discussão para outra ocasião.

Prosseguindo, cumpre não perdemos a noção, referida no capítulo de introdução, de que a metódica proposta fora construída em realidade social distinta e de que, apesar disso, assumimos, reconhecendo essa limitação, que qualquer desvio do comportamento das decisões analisadas em face da teoria apresentada, pode ser derivado de sua genética estrangeira.

Nada obstante, essa limitação não causa prejuízo à pesquisa uma vez que, dados os objetivos propostos, não interessa perquirir pelas causas de qualquer inconformidade verificada, mas, tão somente, atestar a existência dessa inconformidade.

Por outro lado, não podemos deixar de reconhecer que, embora existam importantes diferenças culturais entre o Brasil e a Alemanha, no âmbito do Direito, entretanto, tal problema é menos grave pela singela razão de que estamos diante do mesmo sistema romano-germânico, fato que cria enorme semelhança entre os dois sistemas jurídicos, especialmente em relação ao direito adjetivo, o qual, em termos de estruturação de decisões, é aquele de maior influência.

Ainda no tocante a essa questão das diferenças, por fim, cumpre rebater a objeção de que aplicar à realidade brasileira uma teoria hermenêutica proveniente do outro lado do mundo, seria aplicar uma caricatura dessa teoria, e não a teoria propriamente. De fato, corre-se esse risco quando se pretende um exercício desse tipo, porém, no presente caso, buscou-se extrair, com o esforço despendido no capítulo anterior, apenas o que há de mais geral nessa teoria, a sua metódica, que, em razão de se fundamentar em grande medida no método e na lógica, assume uma feição universal.

Nada obstante, a demonstração da generalidade dessa metódica foge em muito ao escopo do presente trabalho, além do que se torna prescindível já que assumimos que qualquer inconformidade verificada entre a metódica e a prática pode ser decorrente de sua não generalidade, ou melhor, do fato de ter sido erigida em uma realidade cultural distinta.

Assim, mais uma vez, claro está que a Metódica Estruturante fora construída com base numa análise indutiva da hermenêutica constitucional alemã, ou, em outras palavras, 
construiu-se uma teoria concretivista da interpretação das normas jurídicas com base no estudo das fundamentações reveladas pelos documentos produzidos na jurisprudência germânica, isto é, acórdãos, sentenças, despachos etc.

O exercício que se pretende fazer no presente capítulo, que constitui a verificação da conformidade entre essa forma particular de ver o processo interpretativo e o modo como se estruturam as decisões no âmbito do STF, buscando a máxima fidelidade ao modelo, deve, necessariamente, adotar a mesma forma pela qual foi ele engendrado.

É assim que, em uma análise ex post, partiremos de casos concretos já decididos e, com pretensões propositalmente limitadas, analisaremos os votos proferidos nesses julgados para verificarmos não somente a existência de elementos de concreção normativa, porém a própria existência do processo de estruturação moldado pela Metódica, que tenham sido efetivamente levados em conta e adotados pelos juízes, quando do trabalho jurídico.

De fato, a conclusão principal do capítulo precedente foi a de que a identidade da metódica encontra-se não apenas no rol de elementos de concreção, mas principalmente na particular estrutura dinâmica por ela revelada que, envolvendo tais elementos, conforma o processo hermenêutico.

Portanto, necessariamente, a verificação de conformidade deve decorrer da verificação, não apenas dos elementos de concreção, mas também da estrutura dinâmica erigida pela metódica, que é o próprio processo de concreção normativa.

\subsection{Casos Escolhidos}

A seguir elencamos os casos escolhidos para análise, julgados pelo Supremo Tribunal Federal, no âmbito da ordem econômica constitucional.

O critério de escolha compõe-se, primeiramente, da existência, no caso a ser analisado, de discussão a respeito de uma das temáticas que envolvem a ordem econômica, conforme definida no capítulo I, especialmente o princípio da livre iniciativa, a noção de atividade econômica em sentido estrito, a noção de serviço público, os modos de intervenção do Estado na economia, a garantia de proteção do consumidor etc.

Por outro lado, também constitui critério de escolha, porém secundariamente, a importância que o debate assumiu na jurisprudência do Tribunal. Alguns casos, porém, deixaram de ser incluídos na análise pelo fato de corresponderem a temática já tratada em um 
dos demais casos escolhidos.

Tabela III: Elenco de casos escolhidos

\begin{tabular}{|c|c|c|c|}
\hline Casos & Temática & Ação/Recurso & Julgamento \\
\hline Correios & $\begin{array}{l}\text { Atividade econômica em sentido } \\
\text { estrito/Serviço Público/Livre } \\
\text { concorrência }\end{array}$ & ADPF 46-7/DF & 2009 \\
\hline \multirow{3}{*}{ Tablitas } & \multirow{3}{*}{$\begin{array}{l}\text { Intervenção do Estado na economia/ato } \\
\text { jurídico perfeito/ equilíbrio dos } \\
\text { contratos }\end{array}$} & RE $164836 \mathrm{MG}$ & 2006 \\
\hline & & RE $141190 \mathrm{SP}$ & 2005 \\
\hline & & RE 136901-9 SP & 2006 \\
\hline \multirow{2}{*}{ Meia entrada } & \multirow{2}{*}{$\begin{array}{l}\text { Livre iniciativa/Direito à vida, } \\
\text { educação, cultura e desporto }\end{array}$} & ADI 1950-3/SP & 2005 \\
\hline & & ADI 3512-6/ES & 2006 \\
\hline \multirow{2}{*}{ Mensalidades Escolares } & \multirow{2}{*}{$\begin{array}{l}\text { Livre iniciativa/Regulação de preços e } \\
\text { de serviços }\end{array}$} & ADI 319-4/DF & 1993 \\
\hline & & ADI 1007/PE & 2005 \\
\hline Farmácias & $\begin{array}{l}\text { Livre iniciativa/Regulação do horário } \\
\text { de funcionamento do comércio local }\end{array}$ & RE 189170/SP & 2001 \\
\hline Destilaria Alto Alegre & $\begin{array}{l}\text { Livre iniciativa/Regulação de preços do } \\
\text { setor sucroalcooleiro/ Adequação da } \\
\text { intervenção do Estado a parâmetros } \\
\text { legais }\end{array}$ & RE 422941-2/DF & 2005 \\
\hline Apagão & $\begin{array}{l}\text { Prestação de serviço público/garantia } \\
\text { de proteção ao consumidor }\end{array}$ & ADECON 9-6/DF & 2001 \\
\hline
\end{tabular}

\subsection{Aplicando a metódica}

Neste subcapítulo, analisaremos os casos da jurisprudência do STF no campo do direito econômico.

\subsubsection{Caso dos Correios}

Para a análise aqui proposta, escolhemos um caso paradigmático no campo da ordem econômica, porque aborda as temáticas da livre iniciativa, do debate da noção de serviço público, dentre outras, e, no tempo deste trabalho, um caso atualíssimo, porque recentemente decidido de forma terminativa pelo Supremo Tribunal Federal (STF), embora sua discussão tenha se estendido por anos a fio nos Tribunais pátrios.

É o caso do chamado "monopólio" das atividades postais pela Empresa Brasileira de Correios e Telégrafos - ECT, julgado pelo Pleno do STF em 05/08/2009, nos autos da ADPF 46-7/DF, cujo desfecho, adiantamos, estabeleceu, dentre outras coisas, e salvo melhor juízo, a impossibilidade de, com base em elementos da realidade social brasileira presente e 
em face do alargamento do princípio da livre iniciativa e do conceito de serviço público, se mudar a interpretação tradicional da expressão "manter serviço postal", contida no inciso X, do art. 21, da Constituição Federal de 1988, que fora inserida nas constituições brasileiras desde o Império, para deixar de significar o "monopólio" acima referido e passar a corresponder apenas a uma garantia por parte do poder público da existência e do desenvolvimento da atividade, especialmente quando e onde não houver interesse da iniciativa privada.

Contudo, antes de iniciarmos o estudo pretendido, é necessário escrever algumas linhas a respeito de dois fundamentos jurídicos, e constitucionais, que estão em jogo no caso do chamado "monopólio" das atividades postais.

\subsubsection{A Proteção Constitucional à Livre Iniciativa}

Como bem explica Eros Grau ${ }^{144}$, a livre iniciativa é albergada na Constituição, no seu art. $1^{\circ}$, inciso IV e no seu art. 170, caput, como princípio político constitucionalmente conformador:

"Art. $1^{\circ}$ A República Federativa do Brasil, formada pela união indissolúvel dos Estados e Municipios e do Distrito Federal, constitui-se em Estado Democrático de Direito e tem como fundamentos:

$\cdots$

IV - os valores sociais do trabalho e da livre iniciativa;"

"Art. 170. A ordem econômica, fundada na valorização do trabalho humano e na livre iniciativa, tem por fim assegurar a todos existência digna, conforme os ditames da justiça social, observados os seguintes princípios: ..."

Primeiramente, cumpre observar que, ao contrário de muitas leituras que se fazem por aí, a Constituição alberga como fundamento da República não meramente a 'livre iniciativa' de forma isolada, mas verdadeiramente 'o valor social da livre iniciativa', querendo dizer com isso que a nossa Carta Política não empresta à livre iniciativa um significado individualista, de conotação liberal, mas a toma naquilo em que ela tem de socialmente valioso, portanto, expressando um valor social. ${ }^{145}$

Tal constatação se reforça quando se conjuga ao preceito do art. $1^{\circ}$, o do art. 170 da Constituição, uma vez que, neste, claramente opera-se uma preponderância do valor 'trabalho humano' em face do valor 'livre iniciativa' já que somente àquele a Constituição

\footnotetext{
${ }^{144}$ A Ordem Econômica na Constituição de 1988, 12. ed., rev. e atua., São Paulo, Malheiros, 2007, p.200.

${ }^{145}$ E. R. GRAU, A Ordem Econômica..., op. cit., p. 200.
} 
Federal acresce a expressão 'valorização', portanto, é fundamento da ordem econômica a 'valorização do trabalho humano' e a 'livre iniciativa'. ${ }^{146}$

Desse modo, a livre iniciativa, como princípio e fundamento da República, não é tomada como um valor absoluto, mas como um valor socialmente graduado, limitado pelo interesse da sociedade. Nem mesmo na sua origem, nos primórdios do liberalismo econômico, a livre iniciativa encontrou conotação ilimitada, sendo, muito pelo contrário, ${ }^{147}$ a expressão de uma garantia de legalidade.

Eros Grau nos dá conta de que na sua origem a livre iniciativa fora postulada como a liberdade de iniciativa econômica, cuja titular seria a empresa, e, mesmo assim, encontrava tal princípio limitações de ordem tributária e regulamentar. Assim é que já se encontravam tais limitações na chamada Lei Le Chapelier, de 1791, e mesmo antes, no édito de Turgot, de 1776, e, posteriormente, no decreto d'Allarde, de 1791, “cujo art. $7^{\circ}$ determinava que, a partir de $1^{\mathrm{o}}$ de abril daquele ano, seria livre a qualquer pessoa a realização de qualquer negócio ou exercício de qualquer profissão, arte ou ofício que lhe aprouvesse, sendo contudo ela obrigada a se munir previamente de uma 'patente' (imposto direto), a pagar as taxas exigíveis e a se sujeitar aos regulamentos de polícia aplicáveis". ${ }^{148}$ (Grifo Nosso)

Contudo, configura-se um reducionismo equiparar a livre iniciativa à liberdade de iniciativa econômica, ou liberdade de empresa, uma vez que aquela engloba, além desta, a iniciativa econômica individual, a cooperativa (art. $5^{\circ}$, XVIII, e $174, \S 3^{\circ}$ e $\S 4^{\circ}$, da Constituição) e a pública (art. 173, 177, ..., da Constituição), havendo de se entender a proteção constitucional à livre iniciativa como referida a todas as faces com que ela se apresenta. $^{149}$

Por fim, é necessário deixar claro que a exposição feita acima, embora já deite um olhar dogmático sobre o quanto se disse, tem como fim ser introdutória e como motivo ter sido a acepção que representa o escopo dos argumentos jurídicos que permearam o debate jurisprudencial referente ao caso em questão.

\subsubsection{A Noção de Serviço Público}

\footnotetext{
${ }^{146}$ E. R. GRAU, A Ordem Econômica..., op. cit., p. 200.

${ }^{147}$ E. R. GRAU, A Ordem Econômica..., op. cit., p. 203.

${ }^{148}$ E. R. GRAU, A Ordem Econômica... , op. cit., p. 203.

${ }^{149}$ G. BERCOVICI, Os Princípios Estruturantes e o Papel do Estado, in A Constituição Brasileira de 1988 Revisitada: Recuperação Histórica e Desafios Atuais das Políticas Públicas nas Áreas Econômica e Social, v.1, Org. José Celso Cardoso Jr., Brasília, IPEA, 2009, p. 259.
} 
Preliminarmente, cumpre observar que a noção de serviço público, que se debate atualmente, tem como marco normativo-constitucional, especialmente, o art. 175 da Constituição:

“Art. 175. Incumbe ao Poder Público, na forma da lei, diretamente ou sob regime de concessão ou permissão, sempre através de licitação, a prestação de serviços públicos."

Claro está, a meu ver, que, ao ser inserido tal dispositivo no capítulo "Dos Princípios Gerais da Atividade Econômica", supondo uma boa técnica legislativa, quer o legislador originário dizer com isso que a prestação de serviços públicos se constitui verdadeiramente de uma atividade econômica.

De fato, a quase totalidade da doutrina pátria não discute mais se é atividade econômica o serviço público, mas sim, se é o serviço público passível de uma definição, de um conceito, capaz de divisar se determinada atividade econômica é ou não a ele subsumida.

Tal debate é de grande importância uma vez que a caracterização de determinada atividade como sendo um serviço público a sujeita a um regime jurídico todo especial. ${ }^{150}$

Assim, ao mesmo tempo em que, no art. 175, a Constituição Federal faz menção ao serviço público, que incumbe ao Poder Público prestar, no seu art. 173, faz ela menção às atividades econômicas que devem ser preferencialmente exploradas pela iniciativa privada, submetendo-se a um regime jurídico distinto e, em decorrência, chamadas pela quase totalidade da doutrina de atividade econômica em sentido estrito que, conjuntamente com os serviços públicos, compõem as atividades econômicas em sentido lato. ${ }^{151}$

Desse modo, há no debate nacional, sobre a noção de serviço público, duas correntes que se contrapõem: a primeira, numa concepção material, ou essencialista, entende que a noção de serviço público pode ser enquadrada num conceito, numa definição, que possa divisar se determinada atividade é serviço público ou é atividade econômica em sentido estrito; a segunda, numa concepção formal, entende que a noção de serviço público não pode ser enquadrada num conceito, extraído ou não da Constituição e dos normativos infraconstitucionais, mas deve ser serviço público aquele que está dessa forma previsto na lei.

A concepção material tem Eros Grau como um dos mais notáveis defensores. Parte ele da divisão da atividade econômica em atividade econômica em sentido estrito e serviço

\footnotetext{
${ }^{150}$ F. H. AGUILAR, Direito Econômico - Do Direito Nacional ao Direito Supranacional, São Paulo, Atlas, 2006, p. 264.

${ }^{151}$ E. R. GRAU, A Ordem Econômica..., op. cit., p. 105.
} 
público, entendendo este como qualquer atividade indispensável à consecução da coesão e interdependência sociais, de modo que, em decorrência, é necessário que tal atividade esteja, direta ou indiretamente, na incumbência Estatal. ${ }^{152}$

A concepção formal tem como defensores, dentre outros, Celso Antonio Bandeira de Mello, para quem só é serviço público aquela atividade que está submetida ao regime de direito público, isto é, ao regime administrativo; e Maria Sylvia Zanella Di Pietro, para quem o que caracteriza efetivamente o serviço público é o seu regime jurídico e a atribuição da atividade ao Estado por meio de lei. ${ }^{153}$

Uma última questão que se faz necessário dizer a respeito da noção de serviço público, é a de que, parece inquestionável, a Constituição não veda que o Estado atue em nenhum domínio da atividade econômica. Tanto no campo dos serviços públicos, em que é ele o titular, quanto no das atividades econômicas em sentido estrito, pode o Estado atuar, contudo, neste último caso, conforme dispõe o art. 173 da Constituição, a intervenção do Estado somente será permitida em face dos imperativos da segurança nacional ou de relevante interesse coletivo. ${ }^{154}$

\subsubsection{A Análise do Acórdão}

Pois bem, feitas as breves considerações a respeito da livre iniciativa e da noção de serviço público, temos agora condições de apresentar o caso a ser estudado e, após, analisar os elementos de concreção normativa nele presentes.

Contudo, vale ainda relembrar aqui uma observação feita no capítulo anterior referente às dificuldades que se apresentam quando se pretende aplicar a um caso prático o instrumental teórico desenvolvido por Müller, uma vez que tal autor, seguindo a tradição germânica, em seus escritos recorre raramente a exemplos e casos práticos, de modo que no material original em que foi apresentada a Metódica Estruturante há pouco referencial prático que se possa tomar como norte para a tarefa aqui pretendida. ${ }^{155}$

Em decorrência de tal constatação, devemos reconhecer que daqui para frente estamos pisando em terreno acidentado, mas com um objetivo claro e propositalmente pouco pretensioso - o reconhecimento de elementos de concretização da Metódica Estruturante em

\footnotetext{
${ }^{152}$ G. BERCOVICI, Os Principios Estruturantes..., op. cit., p. 262.

${ }^{153}$ G. BERCOVICI, Os Princípios Estruturantes..., op. cit., p. 262.

${ }^{154}$ G. BERCOVICI, Os Principios Estruturantes..., op. cit., p. 263.

155 J. M. ADEODATO, Ética e retórica - para uma teoria da dogmática jurídica, São Paulo, Saraiva, 2002, p. 239.
} 
casos da jurisprudência constitucional brasileira, em matéria afeta à ordem econômica.

\subsection{Relatório}

A Associação Brasileira das Empresas de Distribuição - ABRAED, propôs junto ao Supremo Tribunal Federal, uma Arguição de Descumprimento de Preceito Fundamental ADPF $n^{o}$ 46-7/DF, em face da Empresa Brasileira de Correios e Telégrafos - ECT, pretendendo a declaração da não recepção pela Constituição Federal, da Lei 6.538/78, que teria instituído o "monopólio" das atividades postais por parte da União.

Após ter afastado as preliminares de ilegitimidade ativa, o relator, Min. Marco Aurélio, acolheu o pedido formulado pelo autor declarando não recepcionada pela Constituição a citada lei do "monopólio" sob o fundamento, dentre outros, de afronta ao princípio da livre iniciativa, ressaltando a necessidade de se interpretar a Constituição de modo a lhe dar a maior eficácia possível, diante da realidade vigente, de modo que, constata-se que a expressão "manter o serviço postal", do inciso X do art. 21 da Constituição, teria adquirido conotação diversa daquela tradicionalmente adotada pela doutrina pátria, evoluindo da concepção inicial de significar o "monopólio" da atividade postal, para significar um conjunto de serviços que a União deve garantir e, eventualmente, prestar de forma direta, se inexistente interesse econômico para desenvolvimento da atividade em certos locais do território brasileiro. $^{156}$

Houve voto de vista do Min. Eros Grau que, divergindo do relator, julgou improcedente o pedido, uma vez que entendeu não se tratar de ofensa ao princípio da livre iniciativa, considerando mesmo que nem se pode travar tal discussão uma vez que a Constituição albergou a atividade postal como serviço público, tratando-se, portanto, de regime de privilégio e não de monopólio, passível de prestação pela iniciativa privada somente por concessão ou permissão. ${ }^{157}$

Por fim, prevaleceu o voto do Min. Eros Grau, julgando improcedente o pedido, acompanhado pelos Ministros Joaquim Barbosa, Cezar Peluso, Ellen Gracie, Carlos Brito e Carmem Lúcia. Vencidos o relator, Min. Marco Aurélio, que julgava procedente o pedido, e os Min. Gilmar Mendes, Ricardo Lewandowski e Celso de Mello que julgavam parcialmente

\footnotetext{
156 Informativo STF $\mathrm{n}^{\mathrm{o}}$ 392-1, de 13 a 17 de junho de 2005, disponível [on-line] in http://www.stf.jus.br//arquivo/informativo/documento/informativo392.htm [13-09-2009].

157 Informativo STF $\mathrm{n}^{\mathrm{o}}$ 392-2, de 13 a 17 de junho de 2005, disponível [on-line] in http://www.stf.jus.br//arquivo/informativo/documento/informativo392.htm [13-09-2009].
} 
procedente o pedido. O Min. Menezes Direito declarou suspeição. ${ }^{158}$

\subsection{Os elementos de concreção no caso}

Para podermos analisar os elementos de concreção normativa presentes no caso, nos moldes da Metódica Estruturante, tomaremos, de início, o voto de relatoria ${ }^{159}$ proferido pelo Ministro Marco Aurélio e, em seguida, o voto dissidente vencedor ${ }^{160}$, seguido pela maioria dos juízes da Corte, proferido pelo Ministro Eros Grau, nos autos da ADPF 46-7/DF .

\subsection{Voto do Ministro Marco Aurélio}

Pois bem, para o que nos interessa no presente trabalho, considerando os elementos de concreção normativa, podemos segmentar o voto proferido pelo Min. Marco Aurélio em quatro fases, não necessariamente sequenciais:

1. Tratamento do 'relato do caso' chegando ao 'conjunto de matérias' (Sachverhalt);

2. Reunião do 'conjunto de textos de normas' no 'âmbito da matéria' (Sachbereich);

3. Apresentação do 'programa da norma' (Normprogramm), com especial relevância para o tratamento dado ao 'âmbito da matéria' considerando as teorias, as técnicas hermenêuticas-dogmáticas e os demais meios e estratégias que o jurista considera aplicáveis naquele momento, ao mesmo tempo em que dispõe mais especificamente sobre o 'âmbito da norma' (Normbereich);

4. Momento em que transparece de forma difusa os elementos componentes da norma jurídica (Rechtsnorm) e os da norma de decisão (Entscheidungsnorm), sintetizados no dispositivo do voto.

A primeira fase, portanto, diz respeito ao trabalho jurídico com o 'relato sobre o caso' (Fallerzählung), relato não profissional por meio do qual o caso em questão chega ao conhecimento do profissional do direito. Cita o relator notícia veiculada no endereço eletrônico da ECT:

\footnotetext{
${ }^{158}$ Informativo STF $n^{\mathrm{o}} 409$, de 14 a 18 de novembro de 2005, $\mathrm{n}^{\mathrm{o}} 510$, de 9 a 13 de junho de 2008 e $\mathrm{n}^{\mathrm{o}} 554-1$ e $\mathrm{n}^{\mathrm{o}}$ 554-2, de 3 a 7 de agosto de 2009; disponíveis [on-line] in http://www.stf.jus.br//arquivo/informativo/documento/informativo409.htm ou /informativo510.htm ou /informativo554.htm [13-09-2009].

${ }_{159}$ ADPF 46-7/DF, Relator Min. Marco Aurélio, disponível [on-line] in http://redir.stf.jus.br/paginadorpub/paginador.jsp? docTP $=A C \& d o c I D=60850 /$ [15-01-2013].

${ }^{160}$ ADPF 46-7/DF, op. cit.
} 
“Com mão forte, a ECT (Empresa Brasileira de Correios e Telégrafos) retomou a ofensiva cujo objetivo é aniquilar as pequenas empresas de courier, que pouco a pouco tomam o mercado nacional de encomendas expressas e, segundo os Correios, o de cartas. Os expedientes empenhados: apoio da PF (Polícia Federal) para várias blitzes nas empresas em pontos do país e ações em Tribunais Federais nas regiões com o pedido de fechamento imediato das empresas. A ação não poupa nem as firmas que contratam os serviços como companhia de água, de luz ou mesmo os bancos. A Febraban (Federação Brasileira dos Bancos) não comenta o assunto, mas existem informações que (sic) a entidade está preocupada com o tema". ${ }^{161}$

A segunda fase caracteriza-se pela busca dos dados linguísticos, especialmente dos textos de norma aplicáveis, já considerados em face do caso em discussão. É assim que em determinado trecho afirma o relator:

"É de ressaltar, ainda, que os preceitos tidos por violados são essenciais à ordem constitucional vigente, configurando princípios e fundamentos da República Federativa do Brasil, como a livre iniciativa - comando este previsto no artigo $1^{o}$, inciso $I V$, inserto no Título I, da Constituição Federal, denominado "Dos Principios Fundamentais", também a liberdade no exercício de qualquer trabalho (artigo $5^{\circ}$, inciso XIII), a livre concorrência (artigo 170, cabeça e inciso IV) e o livre exercício de qualquer atividade econômica (artigo 170, parágrafo único)." ${ }^{162}$

E mais adiante afirma ele:

“... Cabe a esta Corte, ao realizar a atividade definidora das normas que estão no texto constitucional, harmonizar o conteúdo do artigo 21, inciso X- "Compete à União: manter o serviço postal e o correio aéreo nacional" -, com os demais valores constitucionalmente protegidos ..." 163

Dados linguísticos são tratados ao longo do discurso como podemos ver a abordagem histórica delineada a partir do momento em que é traçado o caminho do serviço postal nas Cartas Constitucionais brasileiras, desde a Constituição Republicana, no ser art. 34, inc. XV, até à Constituição de $1988 .{ }^{164}$

O elemento genético da interpretação tradicional, na acepção mülleriana, também pode ser identificado no texto, embora em trecho referente a projeto de lei que trata de texto normativo disciplinador dos serviços de telecomunicações, verbis:

"Naquele projeto, havia a referência ao Fundo de Universalização dos Serviços Postais FUSP, à criação da Agência Nacional de Serviços de Correios, como ente regulador, e,

\footnotetext{
${ }^{161}$ ADPF 46-7/DF, op. cit., p. 43.

${ }^{162}$ ADPF 46-7/DF, op. cit., p. 43.

${ }^{163}$ ADPF 46-7/DF, op. cit., p. 44.

${ }^{164}$ ADPF 46-7/DF, op. cit., pp. 45-46.
} 
sobretudo, ao fato de que o serviço poderia ser prestado tanto no regime público, como no regime privado. " 165

A terceira fase, em que se busca o 'programa da norma', é caracterizada pela apresentação das teorias, técnicas hermenêuticas e demais estratégias a serem utilizadas pelo relator para fundamentar suas conclusões. É assim que, em diversos trechos, o relator deixa evidente a sua filiação teórica e ideológica, conforme seguem, verbis:

"Interpretar significa apreender o conteúdo das palavras, não de modo a ignorar o passado, mas de maneira a que este sirva para uma projeção melhor do futuro. Como objeto cultural, a compreensão do Direito se faz a partir das pré-compreensões dos intérpretes. Esse foi um dos mais importantes avanços da hermenêutica moderna: a percepção de que qualquer tentativa de distinguir o sujeito do objeto da interpretação é falsa e não corresponde à verdade. A partir da idéia do 'Círculo Hermenêutico' de Hans Gadamer, evidenciou-se a funcção co-autora do hermeneuta..."

Mais a frente:

"Com isso, quero dizer que a atuação da Corte não pode ser mecânica e apenas repetitiva de interpretações que até puderam fazer sentido em um passado remoto... Cabe ao intérprete, no caso, proceder a uma interpretação evolutiva, reconhecendo que essas 'mutações constitucionais silenciosas' funcionam, na verdade, como atos legítimos de interpretação constitucional. "167

Quanto à filiação ideológica, utilizada fortemente, em longo trecho do voto, como estratégia e fundamento de interpretação, diz ele:

"Se em certa sociedade o Estado prega o dirigismo econômico, mais e mais atividades serão realizadas sob as mãos do Estado e alçadas à condição de serviço público. Ao contrário, se exorta a livre iniciativa e a liberdade econômica, a regra é que os particulares desenvolvam tais atividades livremente, desde que atendam à disciplina própria para cada setor da economia, atuando o Poder Público apenas de maneira subsidiária, quando imprescindível por imperativo de segurança nacional ou relevante interesse coletivo - artigo 173 da Constituição Federal em vigor.

A liberdade de iniciativa constitui-se em uma manifestação dos direitos fundamentais do homem..." 168

Mais ainda:

"A maturidade dos debates econômicos atuais, ao defender-se a observância da livre iniciativa, já não mais revela a retomada da política econômica do liberalismo

\footnotetext{
${ }^{165}$ ADPF 46-7/DF, op. cit., p. 62.

${ }^{166}$ ADPF 46-7/DF, op. cit., pp. 43-44.

${ }^{167}$ ADPF 46-7/DF, op. cit., pp. 44-45.

${ }^{168}$ ADPF 46-7/DF, op. cit., p. 46.
} 
clássico..." "169

“As imperfeições do regime liberal clássico não tardaram a aparecer... A esse modelo contrapôs-se o Estado Social, sob duas vertentes dominantes: o Estado Socialista e o Estado do Bem-Estar, este último consolidado nas democracias ocidentais após a Segunda Guerra Mundial",170

“Acontece que esse paradigma do Estado interventor, parâmetro para as Constituições brasileiras... vem sendo alvo de duras e acertadas críticas... "171

A opção dada a uma consideração do contexto fático, consideração pragmática do ponto de vista semiótico, no processo interpretativo fica clara quando o relator busca um sentido para o verbo "manter", expressão consignada no art. 21, X, da Carta de 1988, exortando a Corte a não olvidar as transformações sociais passadas pelo país ao longo do século, in verbis:

“Em outras palavras, as razões que determinaram a instituição do monopólio do serviço postal permanecem vigentes? Pode a Corte olvidar as transformações sociais e tecnológicas que ocorreram no País nesse meio século e entender que o significado do verbo 'manter', núcleo do inciso X do artigo 21, é o mesmo de dois séculos atrás?",172

É nesse sentido que o relator propugna por uma interpretação que considere a realidade social concreta ao ser enfático na questão da ineficiência do setor público, segundo alega, em face de uma série de fatores, dentre eles, conforme expõe em seu voto: o Spoil System; a utilização de cargos públicos como moeda política; a efetiva ineficiência da gestão da ECT, demonstrada em face do seu último resultado operacional divulgado etc. ${ }^{173}$

Também, verifica-se em todo o texto a utilização do elemento hermenêutico canônico lógico-sistemático, como é o caso do trecho a seguir transcrito:

“A leitura da Constituição revela que o Legislador constituinte, quando quis remeter à necessidade de prestação direta da atividade pelo Estado, consignou-a expressamente, utilizando-se, para tanto, de construções como 'explorar, diretamente ou mediante concessão', para o caso das telecomunicações... ",174

No dispositivo do voto proferido pelo relator encontra-se uma síntese da normajurídica/norma-decisão por ele propugnada, constituindo a quarta fase da segmentação proposta no início desta análise, in verbis:

"Acolho o pleito formulado na inicial para declarar que não foram recepcionados pela

\footnotetext{
${ }^{169}$ ADPF 46-7/DF, op. cit., p. 46.

${ }^{170}$ ADPF 46-7/DF, op. cit., p. 46.

${ }^{171}$ ADPF 46-7/DF, op. cit., p. 46.

${ }^{172}$ ADPF 46-7/DF, op. cit., p. 48.

${ }^{173}$ ADPF 46-7/DF, op. cit., p. 51-52.

${ }^{174}$ ADPF 46-7/DF, op. cit., p. 55.
} 
Constituição Federal de 1988 os artigos da Lei $n^{\circ}$ 6.538/78 que disciplinaram o regime da prestação do serviço postal como monopólio exclusivo da União, - ou, mediante sutil jogo de palavras, em regime de "controle/privilégio exclusivo", conforme quer fazer crer a Advocacia-Geral da União, em memorial entregue a esta Corte - a ser executado pela Empresa Brasileira de Correios e Telégrafos, o que viola os princípios da livre iniciativa, da liberdade no exercício de qualquer trabalho, da livre concorrência e do livre exercício de qualquer atividade econômica, respectivamente disciplinados na Carta Política de 1988 nos artigos $1^{\circ}$, inciso IV, $5^{\circ}$, inciso XIII, 170, cabeça, inciso IV e parágrafo único." ${ }^{175}$

Cumpre observar que o voto proferido pelo Min. Marco Aurélio assume uma posição mais filiada à corrente material, ou essencialista, da noção de Serviço Público, uma vez que defende ser tal noção decorrente de uma necessidade pontual e historicamente determinada de maior intervenção a ser feita pelo Estado em certa esfera da economia, embora afirme não ser possível a caracterização de serviço público por meio de um conceito de sua essência ou do estado natural das coisas. ${ }^{176}$

Por fim, o voto proferido pelo Ministro Marco Aurélio neste caso dos Correios configura, conforme veremos ao final deste trabalho, uma espécie de paradigma em que, comparando com os demais casos analisados, verificaram-se, de forma mais contundente, os elementos de concreção da metódica.

\subsection{Voto do Ministro Eros Grau}

$\mathrm{O}$ voto vencedor, do julgamento referente à ADPF 46-7/DF, foi aquele proferido pelo Min. Eros Grau, que, como já adiantamos, entendeu improcedente a demanda do autor.

Para o que se pretende com o presente trabalho, é bastante afirmarmos a constatação de que o voto aqui analisado situou seus principais argumentos primordialmente no plano formal, abstrato, de interpretação, equivalente ao que se denomina da semiótica jurídica de plano sintático-semântico. Isso talvez decorra, arrisca-se uma explicação, da brevidade com que o ilustre juiz expôs suas razões. Nada obstante, conforme ainda abordaremos ao final, há uma menção no voto aqui analisado a respeito dos argumentos utilizados pelo voto de relatoria no tocante à realidade social concreta.

Assim é que, ao proferir seu voto, o Min. Eros Grau afirma ser incabível a discussão a respeito da recepção ou não, por parte da Constituição de 1988, de um suposto

\footnotetext{
${ }^{175}$ ADPF 46-7/DF, op. cit., p. 67.

${ }^{176}$ ADPF 46-7/DF, op. cit., p. 63.
} 
monopólio do serviço postal conferido por ato normativo infraconstitucional e anterior à constituição, uma vez que, de uma análise sintática-semântico do ordenamento, verifica-se que monopólio diz respeito exclusivamente à atividade econômica em sentido estrito, ao passo que os serviços postais, por ser serviço público por expressa previsão constitucional, somente podem ser referidos, não como 'monopólio', mas como 'privilégio' - um regime jurídico que envolve a exclusividade na prestação do serviço. ${ }^{177}$

Portanto, aderindo a uma concepção formal de serviço público, o Min. Eros Grau defende que o serviço postal é uma espécie de serviço público por definição constitucional, situação em que o próprio texto constitucional eleva uma determinada atividade econômica à condição de serviço público. ${ }^{178}$ Vê-se claramente aí um raciocínio hermenêutico abstrato, distanciado do contexto fático, e, do ponto de vista semiótico, adstrito aos planos sintático e semântico de interpretação.

Mais uma constatação desse fato resulta da afirmação, a seguir transcrita, de que para uma empresa privada poder prestar serviço postal seria necessário que isso estivesse expressamente previsto pela Constituição, o que corresponde a um raciocínio de interpretação, em nossa visão, literal e exaustivo, inerente a um enfoque formal, afastando-se do contexto fático envolvido.

“... para que empresa privada pudesse ser admitida à prestação do serviço postal, que é serviço público, seria necessário que a Constituição dissesse que o serviço postal é livre à iniciativa privada, tal qual o fazem os artigos 199 e 209 em relação à saúde e à educação, os quais podem ser prestados independentemente de concessão ou permissão. Os artigos mencionados excepcionam o art. 175 para dizer que a prestação de serviços de saúde e educação são livres à iniciativa privada.,"179

Vale ainda notar que, ao final de seu voto, o Min. Eros Grau, aproximando-se de uma argumentação que modela o 'programa da norma' com base em teorias, em técnicas hermenêuticas e em outras estratégias aplicáveis, rebate a temática da filiação teórica e ideológica adotada pelo relator e introduz, ainda que de forma incipiente, elementos da realidade social brasileira, conforme segue, in verbis:

\footnotetext{
“... vigentes os artigos $1^{\circ}$ e $3^{\circ}$ da Constituição, exige-se, muito ao contrário do que propõe o voto do Ministro relator, um Estado forte, vigoroso, capaz de assegurar a todos a existência digna. A proposta de substituição do Estado pela sociedade civil, vale dizer, pelo mercado, é incompatível com a Constituição do Brasil e certamente não nos conduzirá a
}

\footnotetext{
${ }^{177}$ ADPF 46-7/DF, op. cit., pp. 88-90.

${ }^{178}$ ADPF 46-7/DF, op. cit., p. 87.

${ }^{179}$ ADPF 46-7/DF, op. cit., p. 90.
} 
um bom destino. ${ }^{180,}$

Por fim, a última observação feita quando da análise do voto relator, porém em sentido oposto, é também válida para a análise do presente voto, ou seja, de que com ele assume-se uma posição mais próxima da corrente formal de concepção de serviço público.

\subsubsection{Considerações Finais Sobre o Caso}

Em uma análise ex post, partimos de um caso concreto já decidido, tomando os votos proferidos nesse julgado para verificarmos a existência de elementos de concreção normativa, nos moldes da Metódica Estruturante, efetivamente levados em contra pelos juízes, quando do trabalho jurídico.

Escolhemos, pela sua pertinência no âmbito da ordem econômica constitucional, o caso do chamado "monopólio" das atividades postais pela Empresa Brasileira de Correios e Telégrafos - ECT, julgado definitivamente pelo Pleno do STF em 05/08/2009, nos autos da ADPF 46-7/DF, cujo desfecho, como vimos, estabeleceu, dentre outras coisas, a impossibilidade de, com base em elementos da realidade social brasileira presente e em face do alargamento do princípio da livre iniciativa e do conceito de serviço público, se mudar a interpretação tradicional da expressão "manter serviço postal", contida no inciso X, do art. 21, da Constituição Federal de 1988, que fora inserida nas constituições brasileiras desde o Império, para deixar de significar o "monopólio" acima referido e passar a corresponder apenas a uma garantia por parte do poder público da existência e do desenvolvimento da atividade, especialmente quando e onde não houver interesse da iniciativa privada.

Considerando os elementos de concreção normativa, segmentamos o voto proferido pelo relator, Min. Marco Aurélio, em quatro fases, que se verificam de forma difusa no discurso e, portanto, não são necessariamente sequenciais:

1. Tratamento do 'relato do caso' chegando ao 'conjunto de matérias' (Sachverhalt);

2. Reunião do 'conjunto de textos de normas' no 'âmbito da matéria' (Sachbereich);

3. Apresentação do 'programa da norma' (Normprogramm), com especial relevância para o tratamento dado ao 'âmbito da matéria' considerando as teorias, as técnicas hermenêuticas-dogmáticas e os demais meios e

\footnotetext{
${ }^{180}$ ADPF 46-7/DF, op. cit., p. 92.
} 
estratégias que o jurista considera aplicáveis naquele momento, ao mesmo tempo em que dispõe mais especificamente sobre o 'âmbito da norma' (Normbereich);

4. Momento em que transparece de forma difusa os elementos componentes da norma jurídica (Rechtsnorm) e os da norma de decisão (Entscheidungsnorm), sintetizados no dispositivo do voto.

Por fim, constatamos que o voto vencedor, em apertada votação, proferido pelo Min. Eros Grau, que divergiu do voto de relatoria, situou seus principais argumentos primordialmente num plano formal, abstrato, afastando-se de considerações de ordem fática.

\subsubsection{Caso das Tablitas}

No item anterior, analisamos o caso dos Correios; no presente, analisaremos um caso igualmente importante, que tramitou no Supremo Tribunal Federal por aproximadamente quinze anos, comumente designado de caso das 'tablitas', mas que na verdade reune inúmeras demandas judiciais que foram travadas em decorrência da instituição pelo Governo Federal de índices deflatores a incidirem sobre contratos vigentes na época de planos econômicos que, por certo período, intentaram conduzir, artificialmente, a inflação a zero.

Entre os anos de 1992 e 2006, vários processos tramitaram no Supremo com base nessa problemática, tendo sido julgados inúmeros recursos extraordinários, dos quais, como emblemáticos, escolhemos para análise aqueles de número 141.190-2/SP, referente ao Plano Bresser; 164.836-8/MG, referente ao Plano Collor II; e, 136.901-9, referente ao Plano Cruzado ou Plano Funaro, havendo o primeiro sido julgado em definitivo em 14/09/2005, ao passo que os demais foram julgados em definitivo em 15/03/2006.

Assim, desses três recursos, o primeiro a ser julgado foi o referente ao Plano Bresser, cujo julgamento se deu em definitivo em 14/09/2005, havendo, por tal razão, se tornado o caso paradigma para os demais, de modo que faremos uso desse acórdão para analisar os votos lá proferidos. Nada obstante, essa abordagem não constitui qualquer prejuízo à análise uma vez que, conforme assentado pelo próprio $\mathrm{STF}^{181}$, embora os três casos tratem de planos econômicos diferentes, as questões postas para apreciação são essencialmente as mesmas, assim como são essencialmente os mesmos os votos proferidos.

\footnotetext{
${ }^{181}$ Vide p. 679 do RE 164.836-8/MG, Relator Ministro Marco Aurélio, Relator Min. Marco Aurélio, disponível [on-line] in http://redir.stf.jus.br/paginadorpub/paginador.jsp?docTP=AC\&docID=215423/ [15-01-2013].
} 


\subsubsection{Introdução}

Em ambos os três casos, a discussão envolve a incidência de índice de deflação (tablita) sobre obrigações financeiras assumidas, em razão da adoção de distintos planos econômicos pelo governo brasileiro entre os anos de 1986 e 2001.

Assim, por exemplo, com a imposição do Plano Bresser, que buscou reduzir a zero a inflação de certo período, de modo a induzir uma estabilidade econômica no país, os contratos de aplicações financeiras, como CDBs (Certificado de Depósito Bancário) com taxa pré-fixada, vigentes a época do plano, que embutiam na taxa de retorno uma estimativa da inflação, foram completamente frustrados em tais estimativas uma vez que durante aquele período, em razão do plano, a inflação artificialmente quedou-se à zero.

Em razão dessa quebra de expectativas geradas pelo plano econômico, e dos prejuízos que causavam a uma das partes do contrato, ao mesmo tempo foi editado dispositivo normativo que previa a incidência de um índice de deflação sobre o rendimento de tais aplicações, de modo a tentar reequilibrar as obrigações das partes contratantes.

No caso do Plano Bresser, foi editado o Decreto-Lei no 2.335/87, com redação dada pelo Decreto-Lei n ${ }^{o} 2.342 / 87$, cuja previsão de índice deflator encontrava-se em seu artigo 13, com base no qual a Recorrida, um Banco de Investimentos, fez incidir tal índice sobre os rendimentos de aplicações em CDB com correção monetária pré-fixada de seu cliente, o Recorrente, de modo que o valor recebido ao final foi inferior àquele contratado inicialmente, o qual embutia na taxa de retorno uma parcela equivalente à inflação prevista do período, servindo de correção monetária.

Em suas razões, o Recorrente alegou basicamente que foram contrariados os preceitos constitucionais dos artigos $153, \S 3^{\circ}$, e 55, da Carta de 1969 , que preconizam os princípios da irretroatividade das leis e do respeito ao ato jurídico perfeito e ao direito adquirido. Além disso, alegou também que se configurou a inconstitucionalidade do DecretoLei $n^{\circ} 2.335 / 87$, uma vez que teria tratado de matéria insuscetível de ser veiculada por meio de tal espécie de ato normativo.

Vale destacar que, nesses casos, o Tribunal de origem manteve a improcedência das ações, prestigiando a decisão em primeira instância, que já havia assim se manifestado.

\subsubsection{Relatório}


Em plenário do STF, em 09/06/1992, o RE 141.190 (Plano Bresser) foi o primeiro a iniciar o julgamento, com voto de relatoria pelo Ministro Ilmar Galvão, não conhecendo do recurso. Após, o RE 136.901 (Plano Funaro) veio a plenário com voto de relatoria do Ministro Marco Aurélio, conhecendo e dando provimento ao recurso.

Em retorno, o RE 141.190 veio com voto de vista do Ministro Celso de Mello, conhecendo e dando provimento ao recurso, e o RE 136.901 veio com voto de vista do Ministro Ilmar Galvão, não conhecendo do recurso. Após, o Ministro Maurício Corrêa pediu vista de ambos os processos, conhecendo em parte o recurso e lhe dando provimento nessa parte.

Foi então trazido a plenário o RE 164.836 (Plano Collor II), com voto de relatoria do Ministro Marco Aurélio, conhecendo e dando provimento ao recurso.

Pedindo vista dos três processos, o Ministro Nelson Jobim negou provimento a todos. Seguiu-se vista da Ministra Ellen Gracie que o acompanhou, negando provimento. Na mesma sessão, o Ministro Maurício Correa reformulou seu voto, passando também a negar provimento a todos os recursos.

O Ministro Marco Aurélio reafirmou seus votos, conhecendo e dando provimento a todos os recursos. Após, seguiu-se vista dos Ministros Carlos Velloso e Sepúlveda Pertence que, seguindo o Ministro Nelson Jobim, também negaram provimento aos recursos. Por fim, na sessão de 14/09/2005, os Ministros Joaquim Barbosa, Cezar Peluso e Gilmar Mendes acompanharam a posição que negava provimento aos recursos.

Do exposto, o RE 141.190 obteve decisão definitiva em 14/09/2005, vencendo a maioria que a ele negou provimento, vencidos os Ministros Celso de Mello e Marco Aurélio que davam provimento ao recurso.

Nas palavras do Ministro Nelson Jobim, que proferiu o voto condutor do acórdão:

"Concluiu-se que a aplicação da TABLITA aos contratos com valor prefixado (Certificado de Depósito Bancário - CDB) celebrados em data anterior ao plano, não violava os princípios de proteção do ato jurídico perfeito e o direito adquirido (art. $5^{\circ}, X X X V I$, da $C F)$.

Entendeu-se que o fator de deflação preservou o equilíbrio inicial dos contratos diante da súbita interrupção do processo inflacionário no bojo da legislação de alteração contexto financeiro e monetário do país. ",182

\footnotetext{
${ }^{182}$ RE 164.836/MG, op. cit., p. 680.
} 


\subsubsection{Os Elementos de Concreção no Caso}

Para os fins pretendidos no presente trabalho - análise dos argumentos apresentados nas decisões com vistas a reconhecer uma organização aos moldes da metódica estruturante, quando menos a existência de elementos de concreção da metódica - serão analisados os votos proferidos pelos Ministros Ilmar Galvão, Celso de Mello, Maurício Corrêa, Nelson Jobim e Marco Aurélio, os quais apresentaram os argumentos que conduziram o debate e, por fim, fundamentaram o acórdão.

\subsection{Voto do Ministro Ilmar Galvão}

Tendo em vista a estrutura proposta pela metódica de Müller, o voto de relatoria proferido pelo Ministro Ilmar Galvão segmenta-se em, basicamente, duas partes: i) apresentação do 'âmbito da matéria' (Sachbereich); e, ii) tratamento do 'âmbito da matéria' para obtenção do 'programa da norma' (Normprogramm), por meio de técnicas hermenêuticas.

Assim, a primeira parte do voto nos remete a uma apresentação do 'âmbito da matéria' (Sachbereich), ou seja, das hipóteses normativas específicas que se aplicam ao caso. De fato, logo no início do voto são apresentados os institutos jurídicos (e implicitamente as normas jurídicas a serem interpretadas no caso) aplicáveis ao caso em questão e o próprio caso, resumidamente, conforme segue:

“... não há afirmar-se a ocorrência de ofensa ao ato jurídico perfeito e ao direito adquirido, pelo fato de o acórdão impugnado haver admitido como legítima a adequação dos certificados de depósito bancário adquiridos pela recorrente, com correção monetária pré-fixada, ao plano de estabilização da economia, por meio da aplicação de deflator. "183

A segunda parte do voto, que, ao contrário da primeira, se desenvolve em extenso arrazoado, realiza um tratamento do âmbito da matéria com vistas à obtenção do programa da norma, aplicando técnicas de hermenêuticas já consagradas como a citação de doutrina e jurisprudência aplicáveis.

De fato, é citada, dentre outras, a doutrina que defende a aplicação imediata de leis que criam ou alteram algum "estatuto legal" ou, de outro modo, que inexiste direito adquirido a determinado regime legal. Cita-se também argumento importado do direito norte-americano, de que há "a prevalência dos poderes federais em matéria monetária sobre os privilégios

183 RE 141.190-2, Relator Ministro Ilmar Galvão, disponível [on-line] in http://redir.stf.jus.br/paginadorpub/paginador.jsp?docTP=AC\&docID=208681/ [15-01-2013], p. 408. 
resultantes de contrato" 184 .

$\mathrm{O}$ voto também traz a diferenciação entre a doutrina nominalista da moeda e a doutrina da valoração da moeda, com a explicação de que "o fenômeno inflacionário, de âmbito mundial, encarregou-se de desacreditar a doutrina nominalista da moeda, segunda a qual se impunha esta pelo valor declarado, não pelo valor intrínseco de que se revestia ou da confiança que inspirava" "185. Com isso, defende o argumento de que os "índices, verdadeiros padrões de valor da moeda, efetivamente, não poderiam deixar de ter aplicação à generalidade das obrigações, como meio de dar estabilidade ao contrato, evitando-se o enriquecimento de uma parte em detrimento da outra" ${ }^{\prime 186}$.

Por outro lado, o voto também se baseia na citação de jurisprudência, especialmente do próprio STF, conforme trecho extraído do acórdão proferido no RE 114.982, pelo Ministro Moreira Alves, conforme segue:

“... as normas que alteram o padrão monetário e estabelecem os critérios para a conversão dos valores em face dessa alteração se aplicam de imediato, alcançado os contratos em curso de execução, uma vez que elas tratam de regime legal de moeda, não se lhes aplicando, por incabíveis, as limitações do direito adquirido e do ato jurídico perfeito..." 187

Aqui, cabe fazer algumas observações a respeito do efetivo reconhecimento de elementos de concreção no voto analisado. Primeiramente, não há uma precisão total na identificação das partes do voto analisado com os elementos de concreção, muito pelo contrário, é fácil ver que o enquadramento realizado comporta uma razoável margem de dúvida e de imprecisão.

De fato, a identificação, na primeira parte do voto, do 'âmbito da matéria' (Sachbereich) é bastante precária uma vez que não se verifica propriamente um processo de seleção de hipóteses normativas com base nos elementos do caso consignados no 'conjunto de matérias' (Sachverhalt). Tal fato fica mais evidente em razão da constatação de que não é citado, exceto implicitamente, qualquer dispositivo normativo em todo o voto.

Por outro lado, de uma primeira e superficial análise do voto, teria sido perfeitamente possível que fosse identificado o 'conjunto de matérias' no relatório produzido pelo Ministro Ilmar Galvão, porém a imprecisão da identificação desse elemento seria ainda mais gritante do que aquela apontada acima, uma vez que naquele relato foram privilegiados

\footnotetext{
${ }^{184}$ RE 141.190-2, op. cit., p. 418.

${ }^{185}$ RE 141.190-2, op. cit., p. 426.

${ }^{186}$ RE 141.190-2, op. cit., p. 430.

${ }^{187}$ RE 141.190-2, op. cit., p. 423.
} 
essencialmente os aspectos processuais do caso.

Vê-se, portanto, em maior medida do que não terem sido identificados precisamente os elementos de concreção, é a constatação de que o voto não se estrutura nos moldes da metódica, não havendo o processo de seleção de elementos correlatos, ora do caso, ora normativos, que se desenvolveria até a elaboração do 'âmbito do caso' (Fallbereich). Há, na verdade, um salto diretamente para o 'programa da norma' (Normprogramm) sem, contudo, que esse elemento de concreção venha a se apresentar em sua integralidade.

Do exposto, verifica-se que o presente voto faz uso em quase toda sua extensão de elementos da hermenêutica tradicional, como argumentos doutrinários e jurisprudenciais, situando-se muito mais próximo de ser um arranjo irregular e aleatório de argumentos com vistas à solução do caso do que de uma decisão estruturada nos moldes da metódica estruturante.

\subsection{Voto do Ministro Celso de Mello}

Prosseguindo, o voto de vista proferido pelo Ministro Celso de Mello, para os fins aqui pretendidos, é segmentado em várias partes em que se verificam respectivamente os seguintes elementos de concreção: i) 'conjunto de matéria' (Sachverhalt); ii) 'âmbito da matéria' (Sachbereich); iii) 'âmbito do caso' (Fallbereich); e, iv) 'programa da norma' (Normprogramm).

O 'conjunto de matérias' (Sachverhalt), relato técnico sobre o caso realizado por um profissional do direito - o magistrado, está descrito no início do voto, conforme segue:

"A instituição financeira ora recorrida, invocando legislação superveniente à pactuação do negócio jurídico celebrado com os recorrentes (...) veio a creditar em conta destes, na data do respectivo vencimento, valores a menor, resultantes dos fatores de deflação aplicados sobre o montante a ser resgatado nos precisos termos do ajuste contratual" ${ }^{\prime 188}$.

O 'âmbito da matéria' (Sachbereich), conjunto de hipóteses normativas selecionadas com base no elemento anterior, é identificável em várias partes do voto, dentre elas, seguem as seguintes, verbis:

“O Decreto-Lei $n^{\circ} 2.335$, de 12/6/87, com a redação que lhe deu o Decreto-Lei $n^{\circ} 2.342$, de 10/7/87, estabeleceu, no que concerne, especificamente, às obrigações contratuais de conteúdo pecuniário, celebradas com cláusula de correção monetária pré-fixada no periodo de $1^{\circ}$ de janeiro a 15 de junho de 1987, que os respectivos valores seriam

\footnotetext{
${ }^{188}$ RE 141.190-2, op. cit., p. 435.
} 
deflacionados no dia do vencimento" ${ }^{189}$.

“... esse ato estatal traduziu ilegítima intervenção normativa do Poder Público na esfera das relações contratuais privadas, com indisfarçável aspecto de ofensa ao postulado constitucional que assegura a intangibilidade dos atos jurídicos perfeitos (CF/69, art. 153, $\S 3^{\circ} ; C F / 88$, art. $\left.5^{\circ}, X X X V I\right)^{\prime \prime}{ }^{\prime 190}$.

“O preceito legal questionado incide no supremo vício jurídico da inconstitucionalidade, pois desrespeitou (...) o postulado fundamental, de ordem tutelar, inscrito no art. $5^{\circ}$, XXXVI, da Carta Federal...",191.

Verifica-se no voto o trabalho propriamente dito para obtenção do 'âmbito da matéria', o qual consiste na seleção (incluindo e excluindo itens) de hipóteses normativas ou institutos jurídicos. Tal fato se sucede, por exemplo, quando é feita pelo magistrado a exclusão do instituto do factum principis dentre aqueles que comporiam o citado elemento de concreção.

“Na verdade, a questão dos deflatores instituidos pelo Decreto-lei n” 2.335/87 (art. 13) (...) não se apresenta associada ao tema do factum principis, eis que, como já enfatizado, inocorreu, quando da edição dos atos estatais referidos, qualquer mudança no padrão monetário nacional",192.

O 'âmbito do caso' (Fallbereich), que representa os fatos relevantes já selecionados com base nas hipóteses normativas do elemento anterior, é trabalhado no texto por meio da explicitação de elementos como os 'contratos de CDB' (Certificado de Depósito Bancário) em relação ao regime jurídico que os alcança, conforme segue:

“Há, portanto, subjacente aos Certificados de Depósito Bancário, uma relação de índole contratual que constitui, enquanto ajuste negocial validamente celebrado pelas partes, um típico ato jurídico perfeito..." ${ }^{193}$.

Por fim, o 'programa da norma' encontra-se no dispositivo do voto proferido, especificamente nos parágrafos a partir do seguinte:

“A norma legal em causa (art. 13 do Decreto-lei $n^{\circ} 2.335 / 87$ (...)) afeta sensivelmente, o conteúdo econômico-financeiro dos contratos celebrados com cláusula de correção monetária pré-fixada (...). Mais do que isso, o preceito em questão - porque aplicável aos contratos que lhe são anteriores - incide na vedação constitucional inscrita no art. 153, $\S 3^{\circ}$, da CF/69 - reproduzida pela vigente Constituição Federal (art. 5 , XXXVI) ... ",194.

Neste ponto, cumpre repetir observação feita no capítulo anterior, válida para a

\footnotetext{
${ }^{189}$ RE 141.190-2, op. cit., p. 443.

${ }^{190}$ RE 141.190-2, op. cit., p. 444.

${ }^{191}$ RE 141.190-2, op. cit., p. 448.

${ }^{192}$ RE 141.190-2, op. cit., p. 454.

${ }^{193}$ RE 141.190-2, op. cit., p. 446.

${ }^{194}$ RE 141.190-2, op. cit., p. 466.
} 
análise de todos os votos deste capítulo, de que a norma jurídica e a norma-decisão ${ }^{195}$ não constituem entidades distintas. A norma-decisão representa o grau de condensação no qual se encontra, em cada caso, a norma jurídica, não constituindo, junto a esta, outra entidade independente. ${ }^{196}$ Assim, poder-se-ia dizer que o trecho do voto acima transcrito é identificável tanto com o 'programa da norma' (normprogramm), elemento essencial da norma jurídica, quanto com a norma-decisão (Entscheidungsnorm), numa leitura que se proporciona maior grau de condensação daquela. De fato, o dispositivo do voto, cujo trecho acima se transcreve, pode refletir também a própria norma-decisão.

Também neste voto, em grande extensão, encontra-se o uso de teorias e técnicas hermenêuticas, especialmente com a utilização de argumentos doutrinários e jurisprudenciais. Assim, por exemplo, o voto cita doutrina que defende ser a irretroatividade da lei, no Brasil, uma norma de caráter fundamental. Também, em outra passagem, desenvolve raciocínio interpretativo que exclui a possiblidade de aplicação à realidade brasileira da doutrina de Roubier $^{197}$, largamente utilizada no voto produzido pelo Ministro Ilmar Galvão.

Assim, desenvolvendo uma argumentação em torno do princípio constitucional da irretroatividade das leis, o voto aqui analisado se organiza de modo congruente com a estruturação da metódica de Müller, apresentando, não todos, porém boa parte de seus elementos de concreção.

\subsection{Voto do Ministro Maurício Corrêa}

Analisando o voto proferido pelo Ministro Maurício Corrêa, não se pode nem mesmo segmentá-lo em partes correspondentes à estrutura da metódica mülleriana uma vez que segue, na verdade, uma organização que aborda, com quase igual atenção, três distintos

${ }^{195}$ Em J. M. ADEODATO, Ética e retórica..., op. cit., p. 249: "Fazendo uma comparação exemplificativa final, com o objetivo de tornar ainda mais clara uma forma complexa de colocar a hermenêutica contemporânea como é a de Friedrich Müller. Texto da norma (art. 155 do Código Penas brasileiro): 'Subtrair, para si ou para outrem, coisa alheia móvel. Pena - reclusão, de 1 (um) a 4 (quatro) anos, e multa' (destacado aqui). Norma jurídica, resultado de todo o trabalho de concretização anterior, vinculado a um caso concreto, no qual determinado sujeito fez ligação clandestina para obter eletricidade sem pagar por isso: 'No texto do artigo 155 do Código Penal brasileiro, o conceito de coisa refere-se a objetos físicos. Palpáveis, e o texto não se aplica quando o objeto em questão é energia elétrica'. Norma decisória, a partir da conclusão de que o caso sob exame é de furto de energia elétrica: 'O agora acusado fulano não sofrerá reclusão de 1 a 4 anos e multa e será inocentado'. Observe-se que é apenas um exemplo de uma concretização. A questão é controversa, provocando inclusive a adução do $\$ 3^{\circ}$ ao referido artigo: 'Equipara-se à coisa móvel a energia elétrica ou qualquer outra que tenha valor econômico'. Sobre o problema do desvio de sinal de TV a cabo, por exemplo, a doutrina hoje debate se lhe aplicaria o conceito de energia, o que é decisivo para subsumir ao artigo do furto (155) ou do estelionato (171).".

${ }^{196}$ F. MÜLLER, Teoria Estruturante da Norma..., op. cit., p. 29.

${ }^{197}$ RE 141.190-2, op. cit., p. 455. 
argumentos: o primeiro, o "conflito de leis no tempo e o ato jurídico perfeito"; o segundo, as "leis dispositivas e leis de ordem pública"; e, o terceiro, o "factum principis e a teoria da imprevisão (cláusula rebus sic stantibus)".

$\mathrm{Na}$ abordagem desses três argumentos o eminente magistrado aplica diversas estratégias e técnicas de interpretação como a citação de extensa doutrina e jurisprudência. Verifica-se também a utilização de elementos canônicos da interpretação, como o elemento histórico, conforme segue:

"Este princípio integra o direito constitucional brasileiro de forma intermitente, tendo seu embrião na Constituição Imperial (...) Depois, passou a fazer parte da legislação ordinária, quando a primitiva Introdução ap Código Civil (Lei 3.071, de 01.01.1916) assim dispôs, in verbis:

'Art. 3. A lei não prejudicará, em caso algum, o direito adquirido, o ato jurídico perfeito, ou a coisa julgada.' ..." 198

Por outro lado, esparsamente, verificam-se também alguns elementos de concreção. Primeiramente, um trabalho, ainda que incipiente, com o 'âmbito da matéria' (Sachbereich), a seleção de hipóteses normativas com base nas características do caso, encontra-se no início da abordagem do primeiro argumento. Já no início da abordagem do terceiro argumento, verifica-se uma breve descrição do 'conjunto de matérias' (Sachverhalt), o relato técnico do caso feito pelo profissional do direito.

Vale assinalar que, já na abordagem do terceiro argumento e, também, na conclusão do voto, encontra-se, esparsamente, o processo de eleição do 'programa da norma', assumindo este uma feição mais precisa no parágrafo 12 do voto, conforme segue:

“12. Fico, assim, numa posição intermediária, que me parece suficientemente estruturada juridicamente e cujos efeitos práticos da decisão trazem uma solução mais justa, ou seja, o contrato vigora integralmente até o factum principis, e partir daí, pela aplicação da teoria da imprevisão expressamente prevista pelo legislador, deflaciona-se apenas os rendimentos supervenientes com a utilização das 'tablitas', preservando-se, desta forma, a integridade do capital investido." 199

Portanto, no presente voto, apenas esparsamente verificam-se elementos de concreção, ainda que poucos. O voto segue uma estrutura que aborda três argumentos trabalhados separadamente com vistas à solução do caso. O primeiro dos argumentos corresponde à conclusão de que no sistema jurídico pátrio as garantias do ato jurídico perfeito não podem ser alcançadas por lei nova, ou posterior, o que equivale a dizer, de outro modo,

\footnotetext{
${ }^{198}$ RE 141.190-2, op. cit., p. 471.

${ }^{199}$ RE 141.190-2, op. cit., p. 495.
} 
que a lei nova não pode retroagir para alcançar o ato jurídico perfeito.

O segundo argumento sentencia que, no Brasil, em razão da garantia do ato jurídico perfeito encontrar-se em nível constitucional, não pode ser ela afetada, mesmo que por um ato normativo que venha a dispor de matéria de ordem pública.

Por fim, o terceiro argumento traz a solução final do caso uma vez que lança mão da teoria da imprevisão ou cláusula rebus sic stantibus para estabelecer a constitucionalidade do ato normativo impugnado tão somente a partir da data em que se deu a ocorrência do 'fato do príncipe', precisamente a partir da edição do próprio Plano Econômico.

\subsection{Voto do Ministro Nelson Jobim}

$\mathrm{O}$ voto proferido pelo Ministro Nelson Jobim sagrou-se vencedor, tendo sido acompanhado pela maioria dos ministros. Em síntese, o voto demonstrou com precisão que os contratos com taxa pré-fixada embutiam uma expectativa futura de inflação equivalente à taxa média de inflação dos últimos meses, implicando em uma expectativa de perda real no período equivalente a 1,356\% ao mês, a qual, em razão da drástica redução da taxa de inflação provocada pelo plano econômico, tornar-se-ia em um ganho real de 18,3\%, onerando abruptamente uma das partes e causando, assim, um enorme desequilíbrio no contrato, porém a adoção do índice deflator recomporia nos exatos montantes o equilíbrio contratual, tendo sido calculado de modo a incidir apenas sobre o rendimento pactuado previamente à queda da inflação que seria, portanto, apropriado a partir da data de edição do plano econômico, mesmo sendo aplicado sobre o valor do resgate. Nas palavras do magistrado:

"O 'princípio da tutela do equilíbrio contratual', referido por CELSO em citação de ORLANDO GOMES, preserva-se exatamente com a aplicação do Fator de Deflação. "200

"No que importa, apesar de incidir sobre o valor de resgate, ela reduz apenas o rendimento pactuado previamente à queda da inflação. "201

Além disso, o voto condutor também sustentou, com grande perspicácia, que não se trata de aplicação da 'teoria da imprevisão' do Direito Privado, mas tão somente da adoção de um meio, a aplicação de índice de deflação, para anular os efeitos do congelamento de preços, instituído pelo plano econômico, sobre os contratos.

"Os ajustes do pacto se mantêm, tal qual nominalmente expressos, na medida em que não haja exógenas intervenções na economia que alterem - externamente - a situação econômica.

\footnotetext{
${ }^{200}$ RE 141.190-2, op. cit., p. 542.

${ }^{201}$ RE 141.190-2, op. cit., p. 546.
} 
Nessa hipótese - sem intervenção -, as partes assumem os riscos de mercado.

$\mathrm{Na}$ medida em que houver tal intervenção - com esses efeitos radicais - impõem-se modificações nos ajustes nominalmente expressos no contrato de forma a preservar o ajuste substancial. "202

Por assim dizer, o fator de deflação seria uma consequência necessária do congelamento, de modo que uma suposta inconstitucionalidade do fator de deflação seria derivada de uma eventual inconstitucionalidade do congelamento instituído pelo plano econômico, tema que, por sua vez, não foi trazido ao debate.

"O fator de deflação é uma conseqüência necessária, no caso, do congelamento.

A inconstitucionalidade do fator de deflação seria derivada de uma eventual inconstitucionalidade da regra do congelamento. ${ }^{203}$

Essas são as linhas gerais do voto, o qual, como até aqui já se pode vislumbrar, foi organizado, basicamente, em torno de argumentos. De fato, após um extenso relatório que vai até o item 9 do voto, no seu subitem 10.1 é produzido um relato sintetizado dos argumentos que fundamentaram os votos precedentes e logo em seguida, a partir do subitem 10.2, inicia-se um extenso arrazoado que trabalha com os fatos ocorridos, de modo a esquadrinhar os diversos aspectos do plano econômico, dos contratos, do congelamento em si, e do fator de deflação, erigindo hipóteses e realizando a demonstração de cada uma delas que, ora rebatem os argumentos que fundamentaram os votos precedentes, ora constroem novos argumentos.

Tal fase de construção de argumentos que, a meu ver, tomando grande parte do voto, vai até o subitem 10.7, quando se encerra com uma discussão sobre a inter-relação entre os planos econômico e jurídico, pode ser enquadrada, tendo em vista a estrutura proposta por Müller, tanto nos contornos do 'conjunto de matérias' (Sachverhalt) - o relato técnico do caso, como já num trabalho de obtenção do 'âmbito do caso' (Fallbereich) - os fatos relevantes selecionados do relato técnico com base nas hipóteses normativas aplicáveis.

Mais uma vez, essa identificação comporta certo grau de imprecisão uma vez que, ao adotar uma organização que progride em função da construção de argumentos, o voto se afasta de uma estrutura como aquela do modelo mülleriano, a qual prevê uma dinâmica de seleção progressiva de elementos correlatos e uma consequente redução de complexidade. Além do que, verifica-se que os argumentos construídos ao longo do voto não são necessariamente correlatos, pelo contrário, apresentam um apreciável grau de autonomia entre eles.

\footnotetext{
${ }^{202}$ RE 141.190-2, op. cit., pp. 552-553.

${ }^{203}$ RE 141.190-2, op. cit., p. 567.
} 
De fato, no subitem 10.2 do voto, ao analisar o Plano Bresser, erige o argumento de que ele produziu uma mudança radical na economia, reduzindo bruscamente a inflação.

"A diferença, entre os quadrimestres, foi de 69,95\% para menor.

O plano produziu uma mudança radical na economia.

Reduziu bruscamente a inflação, 204

No subitem 10.4 do voto, demonstra que, nos contratos com taxa de inflação préfixada, há uma expectativa de inflação futura embutida na taxa de retorno do investimento, que na verdade opera efeitos no valor de resgate, de modo a preservar o poder aquisitivo da moeda no termo final do contrato. Porém, nesse caso, as partes contratantes assumem o risco, calculado, de que a inflação efetiva seja diferente daquela prevista, onerando uma das partes.

"O rendimento real é incerto e aleatório.

$O$ resultado pode tanto ser positivo como negativo.

Dependerá da relação entre a inflação esperada - embutida no contrato - e a inflação

efetivamente verificada.

Neste caso, as partes assumem o risco da operação e apostam nas suas previsões. "205

Vê-se que os dois argumentos acima expostos são completamente autônomos entre si, não havendo qualquer relação entre eles. Porém, ambos são utilizados no item 10.5 do voto para, em conjunto, construir um terceiro argumento de que, nos contratos com taxa de inflação pré-fixada, o congelamento implicou uma quebra total do seu equilíbrio econômico-financeiro.

“Já em relação aos contratos com resgate pré-fixado, a situação é outra.

O congelamento destrói toda a previsão pactuada.

(...)

A redução da inflação - via congelamento - implicou numa quebra total do equilíbrio econômico-financeiro dos contratos, tendo em vista o nominalmente ajustado, em termos da moeda. ${ }^{, 206}$

Já no subitem 10.6 são construídos outros três argumentos autônomos entre si e autônomos em relação aos anteriormente considerados. O primeiro, revela a sua construção com base em uma análise, oferecendo exemplos financeiros, das taxas de inflação efetivamente realizadas no período em comparação com aquelas realizadas anteriormente e que serviram de previsão para inflação futura. Demonstra-se, por cálculo matemático, que sem o fator de deflação importaria em total desequilíbrio do contrato.

"Aqui está a quebra total do equilíbrio econômico-financeiro do contrato, evitado ou

\footnotetext{
${ }^{204}$ RE 141.190-2, op. cit., p. 531.

${ }^{205}$ RE 141.190-2, op. cit., pp. 534-535.

${ }^{206}$ RE 141.190-2, op. cit., p. 535.
} 
minimizado pelo Fator de Deflação "207

O segundo argumento, também por meio de cálculos matemáticos com exemplos financeiros, demonstra que o fator de deflação, apesar de ser aplicado sobre o montante final resgatado, foi calculado de modo a reduzir apenas o rendimento auferido.

"No que importa, apesar de incidir sobre o valor de resgate, ela reduz apenas o rendimento pactuado previamente à queda da inflação. 208

"O fator foi matematicamente calculado para ser aplicado sobre a totalidade do resgate, de modo a facilitar e, mesmo, viabilizar os cálculos. ${ }^{209}$

$\mathrm{O}$ terceiro argumento, da mesma forma que os anteriores, demonstra que o deflator não incidiu nos rendimentos auferidos anteriormente à data do congelamento.

"Por outro lado, a deflação abrangeu o periodo posterior ao dia 16, nao incidindo o fator sobre os dias anteriores." 210

Ao final dessa primeira parte, no subitem 10.7 é realizada uma síntese dos argumentos até aqui construídos, deixando transparecer claramente que o trabalho até aqui realizado desenvolveu uma argumentação de fundo econômico, voltada para a solução do caso, sem a qual não se poderia entendê-lo.

"É fundamental a percepção de que o fenômeno econômico não se distancia do jurídico.

Daí a razão de me ter detido em análise econômica.

A compreensão do caso passa pela compreensão do econômico. "211

Prosseguindo, no subitem 10.8 do voto, ao rebater argumento desenvolvido em um voto proferido pelo Ministro Marco Aurélio em processo referente ao Plano Cruzado, pela primeira vez, verifica-se um trato mais substancial com as hipóteses normativas aplicáveis ao presente caso.

Assim, afasta $^{212}$ a possibilidade de inconstitucionalidade com base no art. $5^{\circ}$, XXXVI, da CF, uma vez que, por um exercício de análise semântica, tal dispositivo aplica-se apenas em caso de prejuízo ao ato jurídico perfeito, ao passo que no caso da tablita não há que se falar em prejuízo, muito pelo contrario, promove ela o equilíbrio do contrato, afastando a ocorrência de prejuízo. Além disso, trabalha ${ }^{213}$ com hipóteses normativas que atribuem competências em matéria monetária (artigos 48, XIII, e 22, VI e VII, da CF).

\footnotetext{
${ }^{207}$ RE 141.190-2, op. cit., p. 541.

${ }^{208}$ RE 141.190-2, op. cit., p. 546.

${ }^{209}$ RE 141.190-2, op. cit., p. 547.

${ }^{210}$ RE 141.190-2, op. cit., p. 550.

${ }^{211}$ RE 141.190-2, op. cit., p. 551.

${ }^{212}$ RE 141.190-2, op. cit., p. 561.

${ }^{213}$ RE 141.190-2, op. cit., p. 562.
} 
Nada obstante, vale aqui a mesma observação feita anteriormente em relação à identificação da primeira parte do presente voto com o 'conjunto de matérias', de que, em razão do voto não se organizar nos moldes da metódica estruturante, mas sim por meio da construção de argumentos voltados para solução do caso, há certo grau de imprecisão no enquadramento de certa passagem como um determinado elemento de concreção.

\subsection{Voto do Ministro Marco Aurélio}

O último voto que interessa ser analisado no caso das 'tablitas' é aquele proferido pelo Ministro Marco Aurélio, que acompanhou o entendimento firmado pelo Ministro Celso de Mello no sentido de julgar inconstitucional a aplicação de índice deflator sobre os contratos com taxa de inflação pré-fixada.

Tendo em vista os fins pretendidos no presente trabalho - análise dos argumentos apresentados de modo a aferir a conformidade com a metódica estruturante, quando menos a identificação de elementos de concreção - pode-se dizer que o presente voto analisado constitui aquele de menor conformidade com a metódica, ou seja, aquele que mais se afastou de um modelo de estruturação, como o aqui estudado.

O voto centra-se, basicamente, em torno de um único argumento. Por meio da análise da natureza do investimento, defende que, ao visar o contrato a segurança do investidor em razão de constituir-se ato jurídico perfeito e acabado, não pode ser ele atingido por lei nova, em virtude da garantia constitucional da intangibilidade desse ato jurídico, como dito, perfeito e acabado.

Se há um elemento de concreção que possa ser identificado nesse voto, com algum esforço, seria o trabalho com o 'conjunto de matérias' que pode transparecer do trecho ${ }^{214} \mathrm{em}$ que é relatado o caso e é feita a análise da natureza do investimento, com a indicação de seus componentes, como as partes, o objeto, inclusive o "acessório", que constituiria a própria estimativa de correção monetária avençada.

Além desse elemento, não é possível identificar qualquer outro. Não há uma descrição explícita do conjunto de hipóteses normativas aplicáveis ao caso, nem mesmo verifica-se qualquer tratamento com o 'âmbito da matéria'. De fato, explicitamente há apenas a referência ao princípio constitucional da intangibilidade do ato jurídico perfeito.

Assim, é de se dizer que o presente voto concentrou-se no trato com um único

\footnotetext{
${ }^{214}$ RE 141.190-2, op. cit., pp. 614-616.
} 
argumento, afastando-se em muito de qualquer organização que possa se assimilar à da metódica estruturante.

\subsubsection{Considerações Finais Sobre o Caso}

No presente item analisamos o caso das 'tablitas', que tramitou no Supremo Tribunal Federal por aproximadamente quinze anos e, na verdade, reúne sob essa designação inúmeras demandas judiciais que foram travadas em decorrência da instituição pelo Governo Federal de índices deflatores a incidirem sobre contratos vigentes na época de planos econômicos, tais como o Plano Bresser, que, por certo período, artificialmente levou a inflação a um patamar quase zero.

Pela sua pertinência, foram analisados os votos proferidos pelos Ministros Ilmar Galvão, Celso de Mello, Maurício Corrêa, Nelson Jobim e Marco Aurélio, os quais apresentaram os argumentos que conduziram o debate e, por fim, fundamentaram o acórdão.

Verificou-se que o voto proferido pelo Ministro Celso de Mello foi aquele que guardou maior conformidade em relação à estrutura proposta pela metódica tomada como modelo. Assim, além de terem sido identificados nesse voto diversos elementos de concreção, também foi possível reconhecer o encadeamento da argumentação no sentido de selecionar elementos correlatos, ora do conjunto de textos de norma, ora do conjunto de fatos.

Necessário que se diga, nos demais votos, com maior ou menor incidência, foram verificados alguns dos elementos de concreção, porém em nenhum deles houve a correspondência entre a sua estrutura argumentativa e a estrutura construída pela metódica estruturante, a qual erige a tese de que a concreção se dá por meio da interação sucessiva de elementos fáticos e narrativos num processo de seleção e de redução de complexidade.

Nesse contexto, o voto proferido pelo Ministro Nelson Jobim se torna emblemático ao adotar uma organização que progride em função da construção de argumentos autônomos que, ao final, concorrem para a solução do caso, afastando-se de uma estrutura como aquela do modelo mülleriano, a qual prevê uma dinâmica de seleção progressiva de elementos correlatos e uma consequente redução de complexidade.

\subsubsection{Caso da Meia-Entrada}

Mais um caso a ser analisado no âmbito da ordem econômica instaurada pela 
Constituição, o caso da meia-entrada refere-se a dois processos paradigmáticos que ingressaram no Supremo Tribunal Federal por meio de ação direita de inconstitucionalidade.

\subsubsection{Introdução}

O processo referente à ADI 3512-6/ES, movida pelo Governador do Estado do Espírito Santo, atacando diploma editado pelo legislativo estadual, a Lei 7.737 do ano de 2004, que concedia a "doadores regulares de sangue" o benefício da meia entrada em "todos os locais públicos de cultura, esporte e lazer", foi julgado em definitivo pelo Supremo no ano de 2006, obtendo como resultado a sentença de improcedência do pedido, firmando o entendimento, em síntese, de que, no sopesamento entre o princípio da livre iniciativa e o direito à vida, deve ser preservado o interesse da coletividade, encontrando-se o referido benefício em consonância com o que o art. $199, \S 4^{\circ}$, da $\mathrm{CF}$, dispõe a respeito do incentivo à coleta de sangue.

Já no processo referente a ADI 1950-3/SP, ajuizada pela Confederação Nacional do Comércio, atacando diploma editado pelo legislativo estadual paulista, a Lei 7.844, lá do ano de 1992, que concedia aos "estudantes regularmente matriculados em estabelecimentos de ensino de primeiro, segundo e terceiro graus, existentes no Estado de São Paulo" o benefício da meia-entrada em "casas de diversão, de espetáculos teatrais, musicais e circenses, em casas de exibição cinematográfica, praças esportivas e similares das áreas de esporte, cultura e lazer do Estado de São Paulo", o julgamento foi proferido no Supremo em novembro do ano de 2005, também culminando com a sentença de improcedência do pedido, em que foi firmado o entendimento, em estreita síntese, de que há de ser preservado o interesse da coletividade quando da composição entre o princípio da livre iniciativa e o direito à educação, à cultura e ao desporto, de modo que o acesso à cultura, ao esporte e ao lazer constitui meio de complementar a formação dos estudantes.

Em ambos os processos sagrou-se vencedor, por maioria, o voto proferido pelo relator, o Ministro Eros Grau. No caso da meia-entrada estudantil, foram vencidos os Ministros Marco Aurélio e Cezar Peluso, enquanto no caso da meia-entrada para doadores de sangue, vencido o Ministro Marco Aurélio.

Em razão dos objetivos aqui traçados e do fato de que os votos são essencialmente os mesmos em ambos os processos, por ser ligeiramente mais abrangente, analisaremos o voto de relatoria proferido no processo referente ao caso da meia entrada dos doadores de sangue. 
Os demais votos analisados, proferidos pelos Ministros Marco Aurélio e Carlos Britto, serão aqueles do processo referente à meia-entrada estudantil paulista.

\subsubsection{Os Elementos de Concreção no Caso}

\subsection{Voto do Ministro Eros Grau}

$\mathrm{O}$ voto de relatoria, proferido nos autos da ação ${ }^{215}$ referente à meia-entrada dos doadores de sangue, se organiza por meio do encadeamento progressivo de argumentos construídos parágrafo a parágrafo. De fato, o método da paragrafação é sobremaneira evidente que se pode, em quase a totalidade, retirar de cada parágrafo o argumento que o preside, conforme segue, por número de parágrafo designado pelo relator:

2 - Começa o encadeamento da argumentação com a afirmação de que a ordem econômica define uma opção pelo sistema capitalista, mas que, todavia, não restringe a intervenção na economia pelo Estado;

3 - Prossegue enunciando os fundamentos da ordem econômica (mundo do ser e do dever-ser) estatuídos nos artigos $1^{\circ}, 3^{\circ}$ e 170 da Constituição;

4 - Dogmatiza que é indispensável ao sistema capitalista a intervenção do Estado na economia;

5 - Enuncia que o mercado, ou os mercados, é nada mais nada menos que instituição jurídica, portanto locus artificialis; além de ser uma ordem que pressupõe uniformidade de conduta, regularidade, que somente é assegurada pelo direito posto;

6 - Elenca os dispositivos da Constituição que dão concreção ao princípio da liberdade, como fundamento da república e da ordem econômica, nos seus artigos $5^{\circ}$, II, VI, IX, XIII, XIV, XV, XVI, XVII, XX, e 206, II;

7 - Em seguida, conclui que a livre iniciativa não se reduz à liberdade de iniciativa econômica;

8 - Prossegue concluindo que a livre iniciativa não pode ser visualizada tão somente como uma afirmação do capitalismo;

10 - Assevera, conclusivamente, que a livre inciativa não pertence apenas à empresa, mas envolve também a iniciativa do Estado;

215 ADI 3512-6/ES, Relator Ministro Eros Grau, disponível [on-line] in http://redir.stf.jus.br/paginadorpub/paginador.jsp?docTP=AC\&docID=363387, [15/01/2013], pp. 93-102. 
11 - Assim é que a Constituição Federal valoriza o trabalho humano em face da livre iniciativa (arts. $1^{\circ}$, IV, e 170);

12 - Continua então afirmando que os preceitos constitucionais da ordem econômica não se interpretam isoladamente;

13 - Exorta que o art. 199, $\S 4^{\circ}$, da Constituição, institui o dever do Estado de estimular a doação de sangue, atuando sobre o domínio econômico por indução;

14 - Esclarece as modalidades de atuação do Estado no e sobre o domínio econômico, demonstrando que as normas de intervenção por indução são de ordem diretiva, no que não preveem sansão, mas prêmio;

15 - Sentencia, por fim, que a lei estadual hostilizada é norma de intervenção por indução prevista no art. 199, $\S 4^{\circ}$, da Constituição Federal.

Vale observar, o voto de relatoria proferido no processo referente à meia-entrada estudantil segue idêntica estrutura de parágrafos, concluindo, porém, em seu parágrafo 16 , que, como já mencionado na introdução do caso, há de ser preservado o interesse da coletividade quando da composição entre o princípio da livre iniciativa e o direito à educação, à cultura e ao desporto.

Prosseguindo na análise do voto, vê-se que, em sua total extensão, foram elencados institutos jurídicos aplicáveis ao caso, explicitando-os e esclarecendo-os, juntamente com os textos normativos que os acolhem.

Assim, do ponto de vista da metódica estruturante, o voto inicia e segue até o fim com uma apresentação do 'âmbito da matéria' (Sachbereich), não se evidenciando qualquer trato com o contexto fático, como o 'conjunto de matérias' (Sachverhalt), como se subentendido estivesse.

Do exposto, a estrutura do voto, em sua inteireza, pode ser compreendida como a construção progressiva de um argumento doutrinário, de autoria própria, para concluir que a lei institui um mecanismo de intervenção do Estado na economia, do tipo intervenção sobre o domínio econômico por indução, em consonância com a Constituição.

\subsection{Voto do Ministro Marco Aurélio}

O voto apresentado pelo Ministro Marco Aurélio, proferido nos autos da ação $0^{216}$ referente à meia-entrada estudantil, pode ser segmentado em duas partes: a primeira, 216 ADI 1950-3/SP, Relator Ministro Eros Grau, disponível [on-line] in http://redir.stf.jus.br/paginadorpub/paginador.jsp?docTP=AC\&docID=266808, [15-01-2013], pp. 64-65. 
construindo argumento com base no trato com a hipótese normativa aplicável ao caso, art. 24, I, CF, defende que não é consentâneo com a Constituição Federal o Estado cumprimentar "com chapéu alheio"; a segunda, desenvolvendo argumento de ordem fática, ou seja, trabalhando com o contexto fático de modo a defender, de forma semelhante à primeira parte, que o benefício da meia-entrada representa um ônus que é transferido à sociedade, sem que haja uma contrapartida.

Do ponto de vista da metódica, a primeira parte do voto pode ser identificada com o 'âmbito da matéria' (Sachbereich), já a segunda parte pode ser identificada com o 'conjunto de matérias' (Sachverhalt) ou, mais imprecisamente, com o 'âmbito do caso' (Fallbereich). Nada obstante, essa identificação é precária, como já dito anteriormente na análise de votos de outros casos aqui apreciados.

\subsection{Voto do Ministro Carlos Britto}

O conciso voto proferido pelo Ministro Carlos Britto, tratando do caso ${ }^{217}$ da meiaentrada estudantil, concentra-se no trato das hipóteses normativas aplicáveis ao caso, arts. 215, 170, III, e 227, da CF, explorando, brevemente, o contexto fático para defender que "a questão do custo é resolvida por um jogo de mercado", ou seja, "o próprio empresário se defende daquilo que lhe é exigido (...) aumentando o valor dos ingressos de suas casas de espetáculo".

Assim como no voto anteriormente analisado, no presente voto seria possível, ainda que precariamente, identificar o trabalho com o 'âmbito da matéria' (Sachbereich), principalmente, e, em menor vulto, com o 'conjunto de matérias' (Sachverhalt).

\subsubsection{Considerações finais sobre o caso}

Da análise dos votos do presente caso, embora se possam identificar, ainda que precariamente, elementos de concreção da metódica estruturante, verifica-se um importante distanciamento entre o modelo erigido por essa metódica e a organização seguida nos votos.

De fato, os votos se organizam em torno da construção progressiva de argumentos orientados para a solução do caso, não se verificando qualquer processo seletivo como aquele que ocorreria a partir do 'relato do caso' (Fallerzählung), obtendo o 'conjunto de matérias' (Sachverhalt), que, por sua vez, também por um processo seletivo, deriva o 'âmbito da matéria' (Sachbereich), e, assim por diante, até a obtenção do 'programa da norma'

\footnotetext{
${ }^{217}$ ADI 1950-3/SP, op. cit., pp. 66-67.
} 
(Normprogramm), elemento de menor complexidade nessa espiral.

\subsubsection{Caso das Mensalidades Escolares}

\subsubsection{Introdução}

Trataremos, neste subitem, de dois processos em que foi discutida a constitucionalidade de lei que, de alguma forma, estipulava disciplina aplicável às mensalidades escolares.

No primeiro processo, referente a ADI 319-4/DF, a ação direta pretendia impugnar a Lei 8.039 , do ano de 1990, de iniciativa do Presidente da República, que dispôs sobre critérios de reajuste das mensalidades escolares, estabelecendo, dentre outras coisas, que os reajustes das mensalidades seriam calculados de acordo com o percentual de reajuste mínimo mensal dos salários em geral, fixado também em Lei Federal daquele ano.

No segundo processo, referente a ADI 1.007-7/PE, a ação direita pretendia impugnar a Lei 10.989, de 1993, editada pelo legislativo pernambucano, que dispôs sobre a data de vencimento das mensalidades escolares naquele Estado, estabelecendo que tal vencimento dar-se-ia no último dia do mês em que ocorresse a prestação dos respectivos serviços educacionais e que os acréscimos previstos em contrato somente ocorreriam a partir dessa data.

A ADI 319-4/DF foi julgada em definitivo no ano de 1993, ao passo que a ADI 1.007-7/PE somente foi julgada em definitivo no ano de 2005, acerca de 12 (doze) anos após a edição do ato objurgado.

No tocante à questão de fundo, referente à inconstitucionalidade da lei, a primeira ação direta terminou com sentença de improcedência, fixando o entendimento de que o Estado pode regular a política de preços e de serviços, mesmo em se tratando do ensino, o qual configura atividade econômica de prestação de serviço.

A segunda ação direta culminou com a sentença de procedência, fixando o entendimento, em sentido diametralmente oposto àquele fixado na primeira, de que os serviços de educação prestados pelo particular, assim como pelo Estado, configuram serviço público e de que, não obstante, a lei impugnada, ao regular o prazo para pagamento das mensalidades, um dos elementos essenciais do contrato, tratou de direito civil, contratual, o qual pertence à 
competência legislativa privativa da União, não podente, portanto, ser objeto de lei estadual pernambucana.

Os dois processos podem ser reunidos no mesmo caso uma vez que, como visto, embora contenham peculiaridades próprias, tratam, em sua parte nuclear, de temática idêntica, qual seja, a possibilidade de imposição por parte do Estado de alguma restrição, quer seja referente ao prazo de vencimento, quer ao preço, sobre as mensalidades cobradas pelas entidades privadas de ensino. Além disso, conforme será visto, a discussão em ambos os processos, salvo no tocante ao problema da incompetência legislativa arguida no caso da lei editada pelo legislativo pernambucano, gira em torno da natureza da prestação do serviço de ensino.

Nesse tocante, vale mencionar que a posição do Ministro Moreira Alves, conforme resurge de seu voto condutor do acórdão proferido nos autos da ADI 319-4/DF, opta pelo entendimento de que o ensino tem a natureza de atividade econômica de prestação de serviços.

"Na Constituição vigente desde 5 de outubro de 1988, a educação em si mesma, independentemente de seu aspecto como atividade econômica de prestação de serviços, é disciplinada como direito de todos e dever do Estado e da família, nos artigos 205 a 214 , em capitulo subordinado ao título 'Da Ordem Social'. Encarada, porém, sob o ângulo de. atividade econômica, a ela se aplicam os princípios gerais da atividade econômica que se encontram nos artigos 170 a 180 que integram o capítulo I do Título VII concernente à Ordem Econômica e Financeira..." ${ }^{218}$ (g.n.)

Por outro lado, a posição vencedora no caso da ADI 1.007-7/PE, na lavra do Ministro Eros Grau, fixou o entendimento de que a atividade de ensino constitui serviço público, ainda que prestada pelo particular.

"Em outra ocasião afirmei que os serviços de educação, seja os prestados pelo Estado, seja os prestados por particulares, configuram serviço público não privativo, isto é, podem ser prestados pelo setor privado independentemente de concessão, premissão ou autorização. São, porém, sem sombra de dúvida, serviço público. " 219

Assim, para os fins aqui pretendidos, importa que analisemos primeiramente os votos proferidos, nos autos da ADI 319, pelos Ministros Moreira Alves, como relator; Marco Aurélio, como voto dissidente; e dos Ministros Celso de Mello e Paulo Brossard. Posteriormente, analisaremos os votos proferidos nos autos da ADI 1.007 pelos Ministros Eros

218 ADI 319-4/DF, Relator Ministro Moreira Alves, disponível [on-line] in http://redir.stf.jus.br/paginadorpub/paginador.jsp?docTP=AC\&docID=918, [15-01-2013], p. 48.

219 ADI 1.007-7/PE, Relator Ministro Eros Grau, disponível [on-line] in http://redir.stf.jus.br/paginadorpub/paginador.jsp?docTP=AC\&docID=266615, [15-01-2013], p. 13. 
Grau, como relator; e, Joaquim Barbosa, como dissidente.

\subsubsection{Os Elementos de Concreção no Caso}

\subsection{Voto do Ministro Moreira Alves}

O Ministro Moreira Alves inicia o seu voto com uma análise dos preceitos constitucionais, ou de outro modo, das hipóteses normativas aplicáveis ao caso, veiculadas no rol dos arts. 209, 170, $1^{\circ}, \mathrm{IV}, 5^{\circ}, \mathrm{XXXII}, 173, \S 4^{\circ}, 174$ e, finalmente, 193, todos da Constituição Federal, para, conforme suas próprias palavras, dar-lhes "sentido relativo de modo a possibilitar a sua conciliação" ${ }^{220}$.

Nos termos de uma hermenêutica tradicional, designar-se-ia essa atividade como sendo a determinação do sentido e do alcance desses preceitos, a par dos demais que lhes circundam, nos limites do caso decidendo. Nos termos da metódica estruturante, o trabalho teria começado imediatamente com a manipulação do 'âmbito da matéria' (Sachbereich).

No trajeto à conclusão, dá-se farto emprego de técnicas hermenêuticas dogmáticas, nos moldes em que postos por Müller, verificando-se a citação de doutrina e jurisprudência aplicáveis, além do uso dos elementos canônicos, histórico e genético, como a seguir transcreve-se, respectivamente.

“...Aliás, já sob o império da Constituição de 1946, esta Corte Admitia, com base no artigo 148 que dispunha que a lei reprimiria toda e qualquer forma do abuso do poder econômico..." 221

"É certo que, entre as funções executivas que esse dispositivo confere, nesse terreno, ao Estado, não consta do texto constitucional vigente a de controle a que aludia, na esteira dos anteriores, o projeto final da Comissão de Sistematização (artigo 203, caput), mas a retirada desse controle in concreto, que daria a possibilidade de ingerência direta do Estado como agente normativo e regulador da atividade econômica, papel esse que se situa no terreno da normatividade e não da execução." ${ }^{222}$

Por fim, conclui, em relação à alegação genérica de inconstitucionalidade, que, verbis:

"E, portanto, para conciliar o fundamento da livre iniciativa e do princípio da livre concorrência com os da defesa do consumidor e da redução das desigualdades sociais, em conformidade com os ditames da justiça social, pode o Estado, por via legislativa, regular

\footnotetext{
${ }^{220}$ ADI 319-4/DF, op. cit., p. 51.

${ }^{221}$ ADI 319-4/DF, op. cit., p. 52.

${ }^{222}$ ADI 319-4/DF, op. cit., p. 53.
} 
a política de preços de bens e de serviços, abusivo que é o poder econômico que visa o aumento arbitrário dos lucros." 223

Assim, o voto adota a sistemática de apreciar primeiro a alegação genérica de inconstitucionalidade em face da livre iniciativa, prosseguindo com as alegações referentes a cada dispositivo da lei hostilizada, adotando continuamente a mesma estrutura de voto, qual seja, a de trabalhar as hipóteses normativas incidentes, sem qualquer alusão ao contexto fático. Nesses termos, salvo pela identificação do elemento de concreção anteriormente referido, o voto se afasta completamente de uma organização nos moldes da metódica estruturante.

\subsection{Voto do Ministro Marco Aurélio}

O voto do Ministro Marco Aurélio adota a sistemática de apreciar dispositivo por dispositivo da lei impugnada, verificando-se, de forma semelhante ao voto anteriormente analisado, intensa manipulação das hipóteses normativas, no sentido de descortinar o que na Metódica Estruturante designa-se por 'âmbito da matéria' (Sachbereich), porém limitando-se a um plano abstrato de dados liguísticos, pura e simplesmente.

A única exceção encontra-se no trecho abaixo transcrito, que aborda, ainda que de modo superficial, fatos relevantes aplicáveis ao caso.

"Inibe a iniciativa privada no que introduz desequilíbrio nas relações jurídicas mantidas entre alunos ou pais de alunos e as escolas, forçando a fuga destas últimas do campo no qual vem atuando (...)Introduz mecanismo de preços que coloca em plano secundário a liberdade de mercado, acabando por forçar os prestadores dos serviços a aceitá-lo, ainda que em prejuizo até mesmo da qualidade do ensino e do empreendimento econômico, ante o evidente achatamento das mensalidades (...) a única alternativa é o abandono das atividades. Pergunta-se: estará o ensino público em condições de fornecer atendimento educacional na hipótese?" 224

Desse trecho, expresso em um único parágrafo, pode-se vislumbrar a variedade de relevantes questões de ordem fática - sociais, econômicas, orçamentárias e até referentes aos efeitos sobre a qualidade do ensino, que poderiam ter sido discutidas em qualquer dos votos apresentados no julgamento dessa ação direta, cuja espécie, por si só, não constitui óbice a uma discussão desse naipe, muito pelo contrário, não se imagina, salvo melhor juízo, qualquer óbice, nem de ordem processual nem de direito material, à condução do debate para um patamar mais conjuntural.

\footnotetext{
${ }^{223}$ ADI 319-4/DF, op. cit., p. 53.

${ }^{224}$ ADI 319-4/DF, op. cit., p. 68.
} 
Inclusive, interessante o trecho a seguir transcrito que demonstra uma clara opção por não se adentrar no contexto fático, de uma análise de ordem econômico-financeira dos efeitos da lei em comento.

"Por isso, sem mesmo entrar no campo das conseqüências econômico-financeiras da Lei em comento, peço vênia ao nobre Ministro Relator para dele dissentir..." 225

Por outro lado, em termos da metódica estruturante, o citado trecho pode ser identificado, mais, com o elemento de concreção do ‘âmbito do caso' (Fallbereich), porém em menor grau com o 'conjunto de matérias' (Sachverhalt) uma vez que não há qualquer evidência de que os fatos arranhados no trecho transcrito decorram do relato por meio do qual o caso em questão chegou ao conhecimento do profissional do direito, condição conceitual desse elemento de concreção.

Bem da verdade, pela mesma lógica, a identificação do trecho com o 'âmbito do caso' também guarda certa imprecisão uma vez que, embora o reconhecimento de fatos relevantes seja elemento comum entre eles, não sendo tais fatos relevantes decorrentes do relato pelo qual o caso vem a conhecimento, como já dito no parágrafo anterior, também, por essa razão, não podem ter sido selecionados do 'conjunto de matérias', sendo essa a condição conceitual daquele elemento de concreção, que não se satisfaz, portanto.

Indo um pouco além, apenas para concluir essa parte, verifica-se que o conteúdo do trecho transcrito aproxima-se muito mais de uma abordagem em torno de argumentos factuais, porém superficiais, como mera técnica de retórica.

\subsection{Voto do Ministro Celso de Mello}

O voto proferido pelo Ministro Celso de Mello, em semelhança aos até aqui analisados, concentra-se no tratamento dos dados linguísticos com a apreciação das hipóteses normativas aplicáveis, exceto por se iniciar com uma introdução ao contexto histórico de fundo, diferenciando-se, assim, em razão da inversão da ordem de apresentação dessas duas partes, isto é, aborda por último o plano abstrato das hipóteses normativas.

É de se dizer, porém, que a apresentação do contexto histórico, embora constitua excelente estratégia de argumentação, não se confunde necessariamente com a apresentação do contexto fático e de fatos relevantes que envolvam o caso, uma vez que estes podem estar ligados essencialmente ao momento presente, ab initio, ao passo que aquele, conquanto tenha relação, ainda que indireta e distante, com o caso, venha a constituir nada mais que elemento ${ }^{225}$ ADI 319-4/DF, op. cit., p. 69. 
de retórica, como bem se pode ver no presente voto, conforme trecho a seguir transcrito.

"O Estado Liberal caracterizava-se pela neutralidade assumida na cena econômica e social. A doutrina do laissez-faire, laissez-passer conferia base ideológica ao liberalismo econômico. O stado Liberal, também denominado de Estado Mínimo ou Absenteísta, não intervinha na ordem econômica e social. Limitava-se a fiscalizar o livre e normal desenvolvimento das atividades de produção. Por isso mesmo foi identificado com o État gendarme..., 226

Por fim, no presente voto vale a mesma observação feita na análise dos anteriores, de que a sua estruturação evolui em função de argumentos que se somam para demonstrar uma determinada e única conclusão, aqui a de que não é defeso ao Estado que interfira no domínio econômico, mesmo em face do princípio da livre iniciativa.

"O princípio da liberdade de iniciativa não tem, desse modo, caráter irrestrito e nem torna a exploração das atividades econômicas um domínio infenso e objetivamente imune à ação fiscalizadora do Poder Público." 227

\subsection{Voto do Ministro Paulo Brossard}

O voto do Ministro Paulo Brossard organiza-se em torno da demonstração de que a lei hostilizada não é conflitante com os dois dispositivos da Constituição invocados para declará-la inconstitucional.

Assim, num primeiro momento, busca demonstrar que a lei não ofende o art. 209, da Constituição Federal, utilizando recurso interpretativo que, segundo afirma, descortina o alcance, o objetivo e a finalidade desse dispositivo, em face do contexto fático que também é apreciado, de modo a concluir que a lei hostilizada não fere o citado art. 209, pelo simples fato de que ele apenas estatui que o ensino não constitui privilégio nem monopólio do Estado, porém não excluindo deste o seu poder regulamentar. A mesma estrutura simplificada é utilizada num segundo momento em que se sustenta, igualmente, não haver lesão ao art. 173, $\S 4^{\mathrm{o}}$, da Constituição.

Em alguns trechos, então, incursionou-se pelo domínio fático, pelo que merece destaque o seguinte:

“Entre nós, pelo menos até onde eu conheço, a regra é no sentido contrário. É que o magistério é muito mais um meio de vida, e o magistério é a parte maior do ensino e da educação. Realmente, nunca se viu um professor enriquecer, nem mesmo os professores vinculados ao sistema oficial. Pode ocorrer uma organização modelada empresarialmente?

\footnotetext{
${ }^{226}$ ADI 319-4/DF, op. cit., p. 72.
}

${ }^{227}$ ADI 319-4/DF, op. cit., p. 77. 
pode! Não nego que possa haver, e não nego até que haja. Mas creio que o preceito constitucional quando fala em abuso do poder econômico, dominação dos mercados, eliminação da concorrência, aumento arbitrário de lucros, não está pensando no Ensino." 228

Assim, em termos da metódica estruturante, embora o voto seja bastante conciso, é possível identificar um esforço de se trabalhar ora com os dados não primariamente linguísticos do âmbito fático, ora com aqueles essencialmente linguísticos das hipóteses normativas aplicáveis. Porém, da mesma forma que já observado em outros votos, no presente não se identifica o processo seletivo e de redução de complexidade que subjaz ao esquema erigido pela metódica.

\subsection{Voto do Ministro Eros Grau}

O voto do Ministro Eros Grau, rememore-se que fora proferido já no ano de 2005, nos autos da ADI 1.007-7/PE, tratando da impugnação da lei pernambucana que pretendeu fixar prazo para pagamento das mensalidades escolares naquele estado, concentrou-se na apreciação das normas constitucionais que disciplinam competência entre os entes federativos, arts. 22, I, 24, V e IX, para concluir que a referida lei teria regulado questão de direito civil, invadindo, portanto, competência legislativa privativa da União. Ficou, assim, no plano abstrato, com enfoque em questão meramente formal.

\footnotetext{
"5. Não vislumbro, no texto normativo, legislação sobre educação ou ensino. Os preceitos tratam tão-somente da estipulação de data do vencimento das mensalidades escolares, matéria de direito contrataual...

6. Cabendo à União privativamente legislar sobre direito civil --- ou seja, sobre contratos --- não compete ao legislador estadual discipliná-los. ${ }^{229}$
}

Vale ressaltar, como já dito na introdução ao caso, o voto cuidou também de fixar o entendimento de que a atividade de ensino constitui serviço público, ainda que prestada pelo particular.

\footnotetext{
"Em outra ocasião afirmei que os serviços de educação, seja os prestados pelo Estado, seja os prestados por particulares, configuram serviço público não privativo, isto é, podem ser prestados pelo setor privado independentemente de concessão, premissão ou autorização. São, porém, sem sombra de dúvida, serviço público." 230
}

\footnotetext{
${ }^{228}$ ADI 319-4/DF, op. cit., pp. 85-86.

${ }^{229}$ ADI 1.007-7/PE, op. cit., pp. 13-14.

${ }^{230}$ ADI 1.007-7/PE, op. cit., p. 13.
} 


\subsection{Voto do Ministro Joaquim Barbosa}

$\mathrm{O}$ voto do Ministro Joaquim Barbosa, nos autos da ADI 1.007-7/PE, gira em torno da demonstração do argumento de que a lei impugnada protege o direito à educação, não invadindo, portanto, a competência privativa da União. Para isso, utiliza largamente das técnicas hermenêuticas de citação de doutrina e jurisprudência aplicáveis.

Não é, assim, uma exposição que, diferentemente dos demais votos analisados no presente caso, deixe de privilegiar a apreciação dos dados primariamente linguísticos, formados dentro do próprio texto normativo.

Relevante asseverar que, apesar de ser possível identificar trechos em que há uma aproximação de uma análise dos dados não primariamente linguísticos, provenientes do relato da situação fática, na verdade, não há propriamente uma manipulação do contexto fático, mas apenas uma leitura do próprio dispositivo atacada que, obviamente, é objeto do pedido, porém não se confunde com a situação fática em si uma vez que, também, constituem dados primariamente linguísticos. Um exemplo disso é o trecho a seguir transcrito, em que se verifica não propriamente uma manipulação com o contexto fático, mas meramente uma leitura da lei impugnada de modo a explicitar que tipo de direito vem ela a proteger.

"Primeiramente, tenho que a norma estadual ora impugnada, ao dispor sobre o contrato de prestação de serviço educacional, estipulando como data para o pagamento das mensalidades escolares o último dia do mês, a fim e evitar, com isso, cobrança antecipada de um serviço, não tem como intuito meramente evitar uma cobrança abusiva por parte dos estabelecimentos escolares, pois, nesse caso, estaríamos apenas diante de disposição sobre direito do consumidor.

Entendo, sim, que a referida lei tem como fim primordial evitar que normas contratuais abusivas afetem e prejudiquem a concretização e o acesso ao direito fundamental da educação por parte daqueles cidadãos que pagam estabelecimentos educacionais privativos pela prestação dos serviços educacionais. " 231

\subsubsection{Considerações Finais Sobre o Caso}

Aqui também, à semelhança do vem sendo constatado nos casos até aqui analisados, verifica-se um importante distanciamento entre o modelo erigido pela metódica estruturante e a organização seguida nos votos.

Além disso, como particularidade do presente caso, retira-se das notas taquigráficas, referentes à discussão em plenário, afirmação do Ministro Eros Grau, de

\footnotetext{
${ }^{231}$ ADI 1.007-7/PE, op. cit., p. 13.
} 
fundamental importância na condução do voto dos demais ministros, a respeito de suposto risco de grave lesão à segurança jurídica caso o resultado final do julgado seja no sentido contrário da decisão anterior que concedera a medida cautelar.

"O SENHOR MINISTRO EROS GRAU (RELATOR): - Ministro Carlos Velloso, essa lei é de 1993. Isto ficou doze anos no Tribunal, que não a examinou, apenas deu uma cautelar; agora vai se levantar um precedente terrivel. Isto é de uma gravidade enorme.

O Sr. Ministro CARLOS VELLOSO - Esse argumento é poderoso, sem dúvida. " 232

Ora, isso evidencia, penso eu, que, transcendendo o voto escrito, a organização em torno de argumentos autônomos também estrutura o discurso falado. Essa constatação revela algo, não sobre o modo de pensar do magistrado, porque inacessível, conforme assumimos, mas sobre a organização do discurso falado, que assim parece se organizar, mais em torno de argumentos autônomos do que com base em estrutura nos moldes da metódica estruturante.

Como exercício de reflexão, apreciemos a seguinte objeção: poder-se-ia dizer que essa constatação não é regra. Regra ou não, para o que nos interessa no presente trabalho, basta a observação de que vem ela a produzir eco com as constatações até aqui retiradas da análise dos demais casos, para pôr em xeque a hipótese de conformação da teoria mülleriana com a prática do Tribunal.

Por fim, vale uma última observação, retirada das notas taquigráficas em conjunto com os votos analisados, no caso do julgamento da ADI 1.007-7/PE, de que o Ministro Eros Grau, assim como os demais, vem a se preocupar com a formação do precedente, exortando a Corte a firmar seu entendimento sobre, além da natureza das estipulações impostas ao serviço de ensino, a própria natureza do serviço de ensino em si, a qual fixa o Eminente Ministro como sendo a de serviço público.

"O SENHOR MINISTRO EROS GRAU (RELATOR): - Temos de atentar muito para os precedentes, porque mais dia, menos dia, esta Corte vai ter de se definir sobre isso. Para mim, apesar de todos os aspectos sociais que salientei, isso é direito das obrigações. " 233

Não é demais lembrar que, já em 1993, há precedente da Corte tratando sobre o assunto, qual seja, nada mais, nada menos, o próprio acórdão, com voto condutor do Ministro Moreira Alves, proferido nos autos da ADI 319-4/DF, analisado anteriormente, cuidando de situar essa problemática no âmbito do regime incidente sobre as atividades econômicas, estrito senso.

"Na Constituição vigente desde 5 de outubro de 1988, a educação em si mesma,

\footnotetext{
${ }^{232}$ ADI 1.007-7/PE, op. cit., p. 34.
}

${ }^{233}$ ADI 1.007-7/PE, op. cit., p. 24. 
independentemente de seu aspecto como atividade econômica de prestação de serviços, é disciplinada como direito de todos e dever do Estado e da família, nos artigos 205 a 214 , em capítulo subordinado ao título 'Da Ordem Social'. Encarada, porém, sob o ângulo de. atividade econômica, a ela se aplicam os princípios gerais da atividade econômica que se encontram nos artigos 170 a 180 que integram o capítulo I do Título VII concernente à Ordem Econômica e Financeira... "234 (g.n.)

Veja-se que, no trecho a seguir transcrito, do voto do Ministro Eros Grau proferido nos autos da ADI 1.007-7/PE, toda uma discussão é posta, como se inédita fosse, sem considerar a jurisprudência firmada pela Corte na ADI 319-4/DF, que dá outros contornos ao tema.

"Essa lei define que o pagamento deverá ser feito no fim do mês. Poderia eventualmente definir que fosse feito dois ou três meses depois? Essa disposição cabe, na ordem das competências definidas pela Constituição, à União. Trata-se de matéria de Direito Civil. A única possibilidade que eu encontraria de concluir em sentido contrário estaria em entendermos que, por se tratar de serviço público, cuidar-se-ia de matéria abrangida pelo chamado Código do Consumidor. Nessa hipótese, cairíamos no domínio condominial das competências da União e do Estado-membro. Mas não se trata disso. Estamos cuidando, aqui, de matéria essencialmente contratual. " 235

Porém, constata-se, dessa observação, que se deu na evolução dessa temática, quando menos uma mudança de jurisprudência, um verdadeiro desrespeito à jurisprudência anterior, uma vez que esta, praticamente, nem citada é.

Apenas para registrar, há, no julgamento da ADI 1.007-7/PE, tão-somente uma breve referência ao acórdão, da lavra do Ministro Moreira Alves, proferido nos autos da ADI 319-4/DF, que foi posta no voto do eminente Ministro Sepúlveda Pertence, o qual, porém, não foi o condutor do acórdão.

“... Senhor Presidente, tenho acompanhado a validação, pelo Tribunal, das restrições impostas, por lei federal, ao mercado do ensino a partir do 'leading case' e do antológico voto condutor do mais civilista de nós todos, o eminente Ministro Moreira Alves, na ADIn 319, quando se mostrou bem que a liberdade de ensino nada tem a ver com um livre mercado de exploração do ensino, dado que a educação é valor e direito social eminente da Constituição." ${ }^{236}$

\footnotetext{
${ }^{234}$ ADI 319-4/DF, op. cit., p. 48.

${ }^{235}$ ADI 1.007-7/PE, op. cit., p. 51.

${ }^{236}$ ADI 1.007-7/PE, op. cit., p. 58.
} 


\subsubsection{Caso das Farmácias}

\subsubsection{Introdução}

O presente caso trata da discussão a respeito da possibilidade do ente federativo local, o Município, interferir no domínio econômico de modo a regular o horário de funcionamento do comércio, em especial das farmácias, no seu espaço territorial.

O julgamento no Supremo do Recurso Extraordinário 189.170-0/SP tornou-se emblemático no âmbito dessa discussão, culminando com o entendimento, conforme se retira da ementa do acórdão, de que:

"A fixação de horário de funcionamento para o comércio dentro da área municipal pode ser feita por lei local, visando o interesse do consumidor e evitando a dominação do mercado por oligopólio." 237

No referido julgamento, o Tribunal de origem havia também adotado o mesmo entendimento ao julgar a apelação nos autos do Mandado de Segurança impetrado DROGASIL S/A, de modo que o recurso extraordinário não foi conhecido pelo STF. A ação mandamental havia atacado a lei municipal 8.794/78, do Município de São Paulo, assim como o Decreto Governamental 28.043/89, que estabeleceram em seus arts. $4^{\circ}$ e $5^{\circ}$, respectivamente, que:

"Art. 4". Fora dos horários normais de funcionamento, não será permitida a abertura das farmácias e drogarias que não estiverem escaladas para o cumprimentos dos plantões obrigatórios, salvo mediante prévia autorização da Secretaria de Higiene e Saúde, por periodos de tempo pré-determinado.

Parágrafo Único. Os infratores do disposto neste artigo serão autuados e os estabelecimentos terão suas portas cerradas no ato, independentemente de reincidência, ou não, requisitada a força policial, se necessário.

Art. $5^{\circ}$. Fora dos horários estabelecidos no artigo $3^{\circ}$ não será permitida abertura das farmácias e drogarias que não estiverem escaladas para cumprimentos dos plantões obrigatórios." ${ }^{238}$

\subsubsection{Os Elementos de Concreção no Caso}

\subsection{Voto do Ministro Marco Aurélio}

237 RE 189.170-0/SP, Relator Ministro Marco Aurélio, disponível [on-line] in http://redir.stf.jus.br/paginadorpub/paginador.jsp?docTP=AC\&docID=230851, [15-01-2013], p. 434.

${ }^{238}$ RE 189.170-0/SP, op. cit., p. 440. 
Verifica-se que o voto de relatoria, proferido pelo Ministro Marco Aurélio, que entendeu pela inconstitucionalidade dos dispositivos atacados, conhecendo e provendo o recurso extraordinário, concentrou-se em apreciar o preceito constitucional, a liberdade de iniciativa privada, que, segundo defende, fora infringido pelo diploma hostilizado. Assim, concentra-se na análise da hipótese normativa aplicável.

É bem de se dizer que, em certo trecho, a seguir transcrito, a argumentação aproxima-se de uma abordagem que levasse em conta o contexto fático, selecionando fatos relevantes, com base nos quais apreciaria a hipótese normativa aplicável.

"No mérito, tem-se que o que decidido conflita com a liberdade de atuação assegurada constitucionalmente, implicando, até mesmo, quanto àquelas farmácias indicadas para funcionar no plantão, verdadeira reserva de mercado, tem-se o prejuízo, com a norma aludida, do próprio consumidor. Poderia a Municipalidade impor funcionamento de farmácias e drogarias, mas jamais proibir que algumas delas abrissem em certos dias. Surge, até mesmo, a contrariedade a ordem natural das coisas, ao princípio da razoabilidade no que a proibição de as farmácias abrirem em certos dias, discrepa do objetivo maior do plantão.", 239

Nada obstante, aí ocorre tão somente uma discussão que, embora tangenciando aspectos fáticos, trabalha em torno de hipóteses teóricas, não concretas, apenas supostamente ocorridas, no sentido mais de avaliar os possíveis efeitos da medida pretendida pela autoridade municipal.

\subsection{Voto do Ministro Maurício Correa}

O voto de vista proferido pelo Ministro Maurício Correa, condutor do acórdão, por maioria em plenário, ao contrário do voto de relatoria, defendeu o entendimento de que os Municípios detém a competência para legislar sobre assuntos de interesse local, nos temos do artigo 30, I, da Constituição, trazendo à discussão jurisprudência do próprio STF que assim se pronunciou, inclusive editando a Súmula 419, abaixo reproduzida.

“Os Municípios têm competência para regular o horário do comércio local, desde que não infrinjam leis estaduais ou federais válidas. " 240

De outro lado, verifica-se que o voto condutor foge completamente da discussão a respeito do possível atentado ao princípio da livre iniciativa, fundamento basal do voto de

\footnotetext{
${ }^{239}$ RE 189.170-0/SP, op. cit., pp. 438-439.

${ }^{240}$ RE 189.170-0/SP, op. cit., p. 444.
} 
relatoria, concentrando-se em aspecto meramente formal, a distribuição constitucional de competências entre os entes federativos.

\subsubsection{Considerações Finais Sobre o Caso}

Os votos analisados no caso das farmácias optaram por abordar questões de ordem texto-normativa, sem uma consideração explícita do contexto fático. Do ponto de vista da metódica estruturante, fica evidente que, embora seja possível identificar o elemento de concreção 'âmbito da matéria' (Sachbereich) - correspondente ao tratamento das hipóteses normativas aplicáveis, não é possível concluir por uma identificação entre a organização adota em ambos os votos e a estrutura dinâmica erigida pela teoria de Müller.

\subsubsection{Caso da Destilaria Alto Alegre}

\subsubsection{Introdução}

$\mathrm{O}$ caso a ser aqui analisado, referente à empresa Destilaria Alto Alegre S/A, adquire importância no âmbito do presente trabalho por tratar das medidas adotadas pelo Governo Federal, em certo período, de fixação dos preços de produtos do setor sucroalcooleiro do Brasil, portanto, de intervenção direta do Estado na formação dos preços de determinado setor da economia.

A Lei 4.870, do ano de 1965, determinava que os preços, dos produtos sucroalcooleiros, seriam fixados pelo Instituto do Açúcar e Álcool (IAA), com obediência aos critérios indicadas pela própria lei. Um dos critérios para fixação do preço, determinado por tal lei, era o levantamento dos custos de produção. Para cumprir tal incumbência, o IAA contratou a Fundação Getúlio Vargas (FGV) para, realizando o levantamento dos correspondentes custos de produção, apurar o preço dos produtos do setor.

Ocorre que o IAA estabelecia os preços dos produtos em valores inferiores àqueles apurados pela Fundação, sendo tal fato incontroverso.

Assim, a Destilaria Alto Alegre, realizando prejuízo no período tratado, moveu ação de indenização contra a União, julgada procedente em $1^{\text {a }}$ Instância, cuja sentença foi mantida pelo Tribunal de origem, o qual, por sua vez, viu reformado o seu acórdão, por decisão do Superior Tribunal de Justiça, contra a qual foi interposto o Recurso Extraordinário 
422.941-2/DF.

Vale frisar que a decisão do STJ foi no sentido de avaliar a licitude do ato que fixou o preço dos produtos sucroalcooleiros em patamar inferior ao valor indicado pela FGV, considerando que tal ato não fora ilícito uma vez que decorreu do poder, do qual o Estado é legítimo detentor, de intervir no domínio econômico.

O julgamento do RE 422.941-2/DF, no âmbito da Segunda Turma do Supremo, contou com voto de relatoria proferido pelo Ministro Carlos Velloso, condutor do acórdão, e voto de vista dissidente do Ministro Joaquim Barbosa. A Segunda Turma decidiu por reformar a decisão proferida pelo STJ, fixando o entendimento de que, conforme ementa:

\footnotetext{
"I. - A intervenção estatal na economia, mediante a regulação de setores econômicos, fazse com respeito aos princípios e fundamentos da Ordem Econômica. CF, art. 170. O princípio da livre iniciativa é fundamento da República e da Ordem econômica: $C F$, art. $1^{\circ}$, IV; art. 170.

II. - Fixação de preços em valores abaixo da realidade e em desconformidade com a legislação aplicável ao setor: empecilho ao livre exercício da atividade econômica, com desrespeito ao princípio da livre iniciativa.

III. - Contrato celebrado com instituição privada para o estabelecimento de levantamentos que serviriam de embasamento para a fixação de preços, nos termos da lei. Todavia, a fixação dos preços acabou realizada em valores inferiores. Essa conduta gerou danos patrimoniais ao agente econômico, vale dizer, à recorrente: obrigação de indenizar por parte do poder público. $C F$, art. $37, \S 6^{\circ} .{ }^{241}$
}

\subsubsection{Os Elementos de Concreção no Caso}

\subsection{Voto do Ministro Carlos Velloso}

$\mathrm{O}$ voto proferido pelo Ministro Carlos Velloso, produzindo extenso trecho com natureza de um verdadeiro relatório, prossegue, concentrando-se no desenvolvimento de uma argumentação que procura estabelecer os limites da intervenção estatal tendo em vista o princípio da livre iniciativa.

"De fato, o texto constitucional de 1988 é claro ao autorizar a intervenção estatal na economia, por meio da regulamentação e da regulação de setores econômicos. Entretanto, o exercicio de tal prerrogativa deve se ajustar aos princípios e fundamentos da Ordem Econômica, nos termos do art. 170 da Constituição." 242

Após, o Eminente Ministro ocupa-se da discussão a respeito da responsabilidade ${ }_{241}^{24}$ RE 422.941-2/DF, Relator Ministro Carlos Velloso, disponível [on-line] in http://redir.stf.jus.br/paginadorpub/paginador.jsp?docTP=AC\&docID=368446, [15-01-2013], p. 654 .

${ }^{242}$ RE 422.941-2/DF, op. cit., p. 672. 
objetiva e do dever de indenizar por parte do Estado, referindo-se a jurisprudência do próprio Tribunal.

Ao que interessa, pode-se reconhecer no voto o trabalho com o 'âmbito da matéria' (Sachbereich), ou, até mesmo, com o 'programa da norma' (Normprogramm), uma vez que trata de definir o conteúdo normativo veiculado pelo art. 170, da Constituição Federal, designando-o como a hipótese aplicável ao caso relatado.

"No caso, a fixação de preços a serem praticados pela Recorrente, por parte do Estado, em valores abaixo da realidade e em desconformidade com a legislação aplicável ao setor constitui-se em sério empecilho ao livre exercício da atividade econômica, em desrespeito ao principio da liberdade de iniciativa." 243

Repetindo achado que vem se tornando frequente, embora se possam identificar no voto um ou mais elementos de concreção, como acima demonstrado, não se verifica nele o processo dinâmico de seleção de hipóteses aplicáveis, ora de ordem fática, ora de ordem textonormativa, pressuposto da metódica estruturante.

\subsection{Voto do Ministro Joaquim Barbosa}

$\mathrm{O}$ voto proferido pelo Ministro Joaquim Barbosa segue uma estrutura em todo semelhante àquela do voto proferido pelo relator. No que interessa para a análise, é possível também reconhecer nesse voto elemento de concreção que busca trabalhar com as hipóteses normativas aplicáveis.

Ao tratar o mérito recursal, diverge do relator por entender que deveria ser dado parcial provimento ao recurso em razão de não haver impugnado o entendimento que lhe fora contrário, fixado no acórdão recorrido, de que não se poderia reconhecer o direito a reajuste de preços, por dano ocasionado pelo Estado às empresas do setor sucro-alcooleiro, durante o período em que vigeu a política de congelamento de preços. Nada obstante, ao final, tal voto restou vencido.

\subsubsection{Considerações Finais Sobre o Caso}

Os dois votos proferidos no caso da Destilaria Alto Alegre seguem uma estrutura semelhante àquela identificada na quase totalidade dos votos analisados nos casos precedentes. De fato, embora se possam reconhecer elementos de concreção em tais votos, não é possível identificar neles o processo dinâmico, nuclear, da metódica estruturante, elemento essencial de

\footnotetext{
${ }^{243} \mathrm{RE} 422.941-2 / \mathrm{DF}$, op. cit., pp. 672-673.
} 
sua identidade ${ }^{244}$. Por outro lado, revela-se nos votos, com maior ou menor evidência, uma organização em torno de argumentos autônomos que concorrem para a formação do enunciado conclusivo, orientado no sentido da solução do caso.

\subsubsection{Caso do Apagão}

\subsubsection{Introdução}

O último caso a ser analisado refere-se à Ação Declaratórica de Constitucionalidade 9-6/DF, movida pelo Presidente da República, que intentava provocar a apreciação por parte do Supremo da constitucionalidade da Medida Provisória 2.152-2, do ano de 2001, que criava e instalava a Câmara de Gestão da Crise de Energia Elétrica e estabelecia diretrizes para programas de enfrentamento dessa crise, comumente designada de crise do Apagão.

A medida judicial, cumulada com pedido de tutela antecipada, visava suspender os efeitos de quaisquer decisões que tivessem afastado a aplicação dos preceitos da citada Medida Provisória, havendo várias decisões que, assim procedendo, ameaçavam a continuidade do programa emergencial de racionalização do consumo de energia, o qual teria sido estabelecido pelo Governo Federal para se evitar um prejuízo maior à sociedade.

O Programa Emergencial de Redução do Consumo de Energia Elétrica, desenhado pela Medida Provisória objeto da ação declaratória, contemplou basicamente três estratégias de atuação: a primeira, correspondente à fixação de metas de consumo decorrentes da crítica situação hidrológica; a segunda, constituìda a previsão de pagamento de tarifa especial por parte daqueles que ultrapassassem a meta estabelecida; e, a terceira, referente à suspensão do fornecimento de energia elétrica na hipótese de descumprimento reincidente da meta.

Para os consumidores residenciais, cuja média de consumo mensal fosse superior a 100kWh, a meta estabelecida pela Medida Provisória foi a de $80 \%$ do consumo médio de energia elétrica verificado nos meses de maio, junho e julho do ano de 2000, portanto, do ano anterior. Assim, cada consumidor adequaria as suas necessidades à execução, autogerida, da meta, elegendo entre formas alternativas de consumo, por meio, por exemplo, do desligamento de eletrodomésticos, da opção por lâmpadas "frias", da redução do uso de chuveiro e ferro

\footnotetext{
${ }^{244}$ Vide conclusões da seção - esforço de compilação - do capítulo II desta monografia.
} 
elétricos etc.

Aos "não-solidários" consumidores, teria sido planejada a aplicação de suspensão do fornecimento de energia elétrica, como instrumento para compelí-los à regular observação das medidas estabelecidas, ao passo que, aos consumidores que já consumiam abaixo de $100 \mathrm{kWh}$, isentou-se o cumprimento das medidas de racionamento uma vez que, em razão de já realizarem um baixo consumo, afigurar-se-ia excessiva a exigência de uma ainda maior redução de seu consumo.

Várias questões foram discutidas no julgamento dessa ação declaratória pelo Supremo, porém, em razão do campo de estudo aqui delimitado, interessa a discussão que se deu em torno das garantias constitucionais à prestação de serviço público de qualidade, sem interrupções e falhas, previstas no parágrafo único do art. 175, da CF; e da garantia constitucional à defesa do consumidor, prevista nos arts. 5 XXXII, e 170, V, da CF, conforme trecho retirado do relatório produzido no voto do relator, a seguir transcrito:

"Sustenta o requerente que, tendo em conta o 'âmbito normativo exposto, desfaz-se, definitiva e integralmente, a alegada violação aos arts. $5^{\circ}, X X X I I$ e LIV, e 170, V, da Constituição Federal'(fls. 110), tendo em conta promover a referida Medida Provisória 'a defesa do consumidor em condições de escassez, pois, por meio do racionamento, promove, sob um nível de consumo menor, a utilização racional, universal e contínua de um bem, no momento, escasso.'(fls. 111).", 245

Também, tendo em vista o objetivo proposto no presente trabalho, foram escolhidos para análise os votos proferidos, em sede de discussão da medida liminar, pelo Ministro Néri da Silveira, relator, e pelo Ministro Nelson Jobim, voto dissidente. O primeiro proque, além de relator, trouxe voto que indeferiu o pedido de tutela antecipada, já o segundo, porque, além de trazer voto divergente daquele proferido pelo relator, apresentou uma estruturação argumentativa peculiar, diferente daquela verificada na maioria dos votos até aqui analisados, constituindo tal fato, inclusive, a razão principal para inclusão do presente caso no rol daqueles em análise.

\subsubsection{Os Elementos de Concreção no Caso}

\subsection{Voto do Ministro Néri da Silveira}

O voto proferido pelo Ministro Néri da Silveira inicia com um relato do caso, 245 ADECON 9-6/DF, Relator Ministro Néri da Silveira, disponível [on-line] in http://redir.stf.jus.br/paginadorpub/paginador.jsp?docTP=AC\&docID=883, [15-01-2013], pp. 70-71. 
explicando as principais nuances da Medida Provisória 2.152-2/2001, passando, em seguida, para uma discussão a respeito da natureza da tarifa especial prevista, depois, entrando nas questões que aqui mais interessam, entra na discussão a respeito das garantias constitucionais à correta e regular prestação de serviço público, no caso serviço de fornecimento de energia elétrica, apreciando o art. $175 \mathrm{da} \mathrm{CF}$, coforme segue:

"Pois bem, embora a redação não-explícita do inciso III do parágrafo único do art. 175 da Constituição atual, em confronto com o inciso II do art. 167 da Carta precedente, não cabe concluir que a obrigação de o Poder Público manter a justa remuneração do capital, assim como assegurar o equilíbrio econômico financeiro do contrato haja sido eliminada do sistema em vigor." ${ }^{246}$

Por outro lado, continua:

“De outra parte, a Constituição, em seu art. 175, II, assegura 'os direitos dos usuários'dos serviços concedidos. Cumpre, neste ponto, entender que aos usuários, a par do poder concedente, está reservado o direito de fiscalizar o correto desempenho do serviço, não podendo o concessionário negar-lhe ou interromper-lhe a prestação do serviço... " 247

Verifica-se que o voto adota a estratégia comumente utilizada da citação de jurisprudência do próprio Tribunal e de doutrina como, por exemplo, a de Hely Lopes Meireles, conforme segue:

"Hely Lopes Meirelles, cuidando do tema, especifica cinco princípios de presença obrigatória na prestação de serviço público: generalidade, permanência, eficiência, modicidade e cortesia..." 248

Por fim, conclui essa parte, ou seja, a argumentação a respeito do que se espera da prestação de um serviço público, com apreciação expressa dos dispositivos constitucionais que regulam a proteção dos usuários de serviço público, conforme segue:

"Serviço adequado, pressuposto de toda a concessão ou permissão, a teor do art. 175, IV, da Constituição, e ex-vi do art. $6^{\circ}, \$ 1^{\circ}$, do mesmo diploma legal, 'é o que satisfaz as condições de regularidade, continuidade, eficiência, segurança, atualidade, generalidade, cortesia na sua prestação e modicidade das tarifas’.

Eis assim como se integra o sistema da Constituição de 1988, no que concerne aos usuários, onde presente também o princípio da isonomia. ", 249

Após, o Eminente Ministro ocupa-se da discussão a respeito do problema, não mais do direito do usuário de serviço público, mas do direito do consumidor, conforme segue:

"De outra parte, no sistema da Constituição de 1988, entre os direitos e garantias

\footnotetext{
${ }^{246}$ ADECON 9-6/DF, op. cit., p. 86.

${ }^{247}$ ADECON 9-6/DF, op. cit., p. 86.

${ }^{248}$ ADECON 9-6/DF, op. cit., p. 87.

${ }^{249}$ ADECON 9-6/DF, op. cit., pp. 87-88.
} 
individuais e sociais, inscreveu-se, no art. $5^{\circ}$, XXXII, que 'o Estado promoverá, na forma da lei, a defesa do consumidor', reafirmando-se esse propósito do constituinte, ao definir os princípios gerais da atividade econômica, quando do art. 170, V, ... "250

A sua conclusão final pode ser extraída do seguinte trecho:

"Do exposto, não há, destarte, espaço a invocar-se, no sistema do art. 5', XXXII, combinado com o art. 170, II e IV, todos da Constituição, legitimidade constitucional para a suspensão do fornecimento de serviço essencial concedido, como o de energia elétrica, àqueles usuários, consumidores finais ... "251

Assim, evidente está que o voto do Ministro Néri da Silveira, em síntese, concentrou-se na análise das hipóteses normativas aplicáveis, especialemente os arts. $5^{\circ}, 170$ e 175 da CF, para concluir pelo indeferimento da medida cautelar, de modo que pouca, ou nenhuma, referência procedeu a respeito do contexto fático ou de fatos relevantes presentes no caso.

Do ponto de vista da metódica, pode-se identificar no voto o elemento de concreção do 'âmbito da matéria' (Sachbereich), as hipóteses específicas escolhidas do conjunto de textos de norma, não sendo possível identificar, de outro lado, a interação com elementos fáticos, não primariamente formados pela linguágem. Assim, seguindo uma regra verificada nos votos analisados no presente trabalho, também não é possível verificar neste voto o processo de concreção normativa típico da Metódica Estruturante.

\subsection{Voto do Ministro Nelson Jobim}

Assim como no voto precedente, o voto proferido pelo Ministro Nelson Jobim se inicia com uma descrição do relato técnico do caso, porém, ao se concentrar na consideração de hipóteses presentes no contexto fático, progride de forma totalmente diferente do anterior, configurando uma característica que também é inusitada quando se pensa no conjunto de votos analisados neste trabalho.

De fato, conforme se pode verificar do trecho a seguir transcrito, o voto trata essencialmente da apreciação de argumentos de ordem fática:

“Agora, a pergunta: por que a suspensão do fornecimento se teria sobretarifa? É fácil compreender. Vejam o seguinte: um cidadão com consumo de $2000 \mathrm{~kW}$ teria que ter uma redução para 1600, ou seja, teria que reduzir 400. Se ele consumir 400, vai ter que pagar, sobre os 400, 50\% de sobretarifa e esse cidadão é dono de uma grande empresa, de um grande conjunto habitacional nos Lagos de Brasília, é dono de um grande conjunto

\footnotetext{
${ }^{250}$ ADECON 9-6/DF, op. cit., p. 88.

${ }^{251}$ ADECON 9-6/DF, op. cit., p. 90.
} 
habitacional no Morumbi. Ele tem excedente monetário para remunerar este excedente e pagar a sobretarifa, ou seja, tem condições de estabelecer técnicas pelas quais, pela sua capacidade financeira e seus excedentes líquidos financeiros, tema a capacidade manter-se no consumo além das metas. E a única solução é, exatamente, determinar a suspensão do fornecimento por três dias. E acredito que, se esse cidadão for um cidadão de condições extraordinárias, terá condições, inclusive, por meio de geradores próprios que vai adquirir e já conhecemos vários que o fizeram, para estabelecer esta linha... "252

Assim é que, até o final, o presente voto, utilizando uma estrutura não habitual, deixa de lado qualquer consideração das hipóteses normativas aplicáveis, concentrando-se, essencialmente, na apresentação de argumentos de ordem fática, provenientes até da ciência econômica, conforme transparece do trecho a seguir transcrito, para julgar, diferentemente do voto de relatoria, procedente a medida liminar requerida, inclusive antecipando o julgamento de mérito da ação declaratória, do qual não se trata aqui apenas por mera conveniência em função dos objetivos pretendidos.

“...Se não tivermos regras pelas quais possa se adequar a oferta ‘a demanda, o que teremos? Teremos aquilo que é nominado pela linguagem comum de 'apagão'.

Devemos lembrar que o direito subjetivo, eventual, que possa se ter em relação ao fornecimento de energia elétrica é do que se tem, porque aqui estamos perante o direito a uma prestação e não um direito potestativo. É um direito que se satisfaz por meio de uma prestação e esta depende da capacidade de oferta. Se a capacidade de oferta reduziu-se, devem-se ajustar os consumidores a esta capacidade de oferta." ${ }^{253}$

Por fim, do ponto de vista da metódica, pode-se entender que o presente voto apresentou um tratamento com o elemento de concreção do 'âmbito do caso' (Fallbereich), portanto, do conjunto de fatos relevantes ao caso em questão. Porém, ao deixar de fazer qualquer consideração às hipóteses normativas aplicáveis, no sentido de serem um parâmetro para seleção dos referidos fatos relevantes, deixou de ter uma organização nos moldes da Metódica Estruturante.

\subsubsection{Considerações Finais Sobre o Caso}

Os dois votos proferidos no caso do Apagão não apresentaram resultado distinto daquele verificado na grande maioria dos votos até aqui analisados. De fato, aqui também, embora se possam reconhecer elementos de concreção como aqueles da Metódica Estruturante, não se encontra presente o próprio processo de concreção normativa que lhe é

\footnotetext{
${ }^{252}$ ADECON 9-6/DF, op. cit., p. 105.

${ }^{253}$ ADECON 9-6/DF, op. cit., p. 107.
} 
inerente, o qual pressupõe uma estrutura dinâmica seleção de elementos relevantes e de redução de complexidade.

Além disso, cumpre observar que o voto proferido pelo Ministro Nelson Jobim, além de apresentar uma estrutura inédita em relação aos votos até aqui analisados, concentrando-se em argumentos de ordem essencialmente fática, revelou uma estrurura que mais se aproxima de uma organização em torno de argumentos autônomos, inclusive retirados diretamente da ciência enconômica sem qualquer correspondência a hipóteses normativas aplicáveis. 


\section{CONSIDERAÇÕES FINAIS}

São retomadas, nesta parte, as principais idéias que marcaram o desenvolver deste trabalho, ainda que isso possa tornar repetitiva a exposição, uma vez que o que se pretende aqui é, além de uma nota conclusiva, uma síntese em face dos reclamos de complexidade do assunto tratado.

Primeiramente, cumpre relembrar o objetivo a que nos propusemos de proceder à análise de argumentos utilizados na jurisprudência do STF no campo da ordem econômica, tendo como referencial teórico a metódica jurídica construída por Friedrich Müller. Intentávamos responder aos seguintes questionamentos: por um lado, em que medida a metódica estruturante descreve a organização argumentativa das decisões do STF e, de outro lado, em que medida apresenta-se estruturada a argumentação jurídica das decisões do STF à luz da metódica.

Assim, logo no início do caminho percorrido apresentamos a concepção do termo ordem econômica presente no título do trabalho. Fixamos o conceito, retirado dos escritos de Eros $\mathrm{Grau}^{254}$, de que 'ordem econômica' corresponde ao um conjunto de princípios e regras da ordem jurídica, portanto parcela desta, que institucionaliza uma determinada 'ordem econômica', a qual, por sua vez, corresponde às relações e atividades econômicas de certo modo de produção, em certo lugar; portanto, refere-se ao modo de produção capitalista que no Brasil intenta-se conformar.

Dessa definição, relacionamos as temáticas que envolvem a ordem econômica e que, por outro lado, determinaram os casos a serem estudados, a saber: a livre iniciativa, a livre concorrência, a defesa do consumidor, a intervenção do Estado na economia e seus modos, a definição de atividade econômica em sentido lato e em sentido estrito, a definição de serviço público, a liberdade de exercício de atividade econômica, a repressão ao abuso do poder econômico, o Estado como agente normativo e regulador da atividade econômica etc.

No capítulo seguinte, nos apropriamos de parte do referencial teórico da Metódica Estruturante, especificamente a 'metódica jurídica' concebida por Friedrich Müller, para construir um referencial teórico, um parâmetro de estruturação de decisões, com o maior nível de generalidade que pudéssemos alcançar.

Com sua metódica, demonstra Müller que “é necessária uma nova teoria do

254 GRAU, E. R., A Ordem Econômica na Constituição de 1988, 12. ed., rev. e atua., São Paulo, Malheiros, 2007, p. 72. 
direito, que conceba o trabalho jurídico como um processo a ser realizado no tempo, e os enunciados nas codificações como textos de normas, i.e., como pré-formas legislatórias da norma jurídica, que por sua vez está por ser produzida no decurso temporal da decisão. De outro modo, a norma jurídica não existe 'ante casum': o caso da decisão é co-constitutivo. $\mathrm{O}$ texto da norma no Código legal é apenas um dado de entrada do processo de trabalho chamado "concretização"”. ${ }^{255}$

Desenvolvemos mais essa concepção metodológica e concluímos que a norma vai sendo construída pelo intérprete no decorrer do processo de concretização do direito. Em outras palavras, a concretização implica um caminhar, do texto da norma e dos fatos, na direção da norma jurídica, que ainda não é o destino a ser alcançado, uma vez que a concretização somente se realiza plenamente quando, por fim, é definida a norma de decisão, apta a dar solução ao conflito que consubstancia o caso concreto. ${ }^{256}$

Mais uma vez reproduzimos as palavras de Müller: "só se pode falar em uma metódica jurídica como práxis metódica, como modo de trabalho cotidiano de 'trabalhadores jurídicos ${ }^{257}$, de titulares profissionais de funções tais como juízes, funcionários administrativos, promotores públicos, membros de órgãos legislativos, etc. ${ }^{258}$ Não se pode falar de uma metódica jurídica 'como tal' no sentido de uma área de análise abstratamente delimitável, de modo que se torna sem sentido uma indagação do lugar da metódica jurídica, epistemologicamente considerado". 259

É assim que, para Müller, a função da metódica jurídica, em termos da teoria jurídica, deve consistir em "elaborar, formular regras para a imputação das normas de decisão estabelecidas nos casos concretos às normas jurídicas gerais indicadas como existentes por trás dessas normas de decisão, de modo que a solução de casos jurídicos é uma técnica decisória, a metódica jurídica como metódica da fundamentação explanadora da decisão é uma técnica de imputação". ${ }^{260}$

Entendemos, então, que a Metódica Estruturante, ao ser concebida a partir de um modo efetivo de produzir efeitos, próprio do ordenamento jurídico, e não a partir de um

\footnotetext{
${ }^{255}$ F. MÜLLER, O Novo Paradigma do Direito - Introdução à teoria e metódica estruturantes do direito, trad. port. de P. Naumann, São Paulo, Revista dos Tribunais, 2007, p. 11.

${ }^{256}$ E. R. GRAU, Ensaio e discurso..., op. cit., p. 29.

${ }^{257}$ F. MÜLLER, Direito, linguagem, violência..., op. cit., pp. 207-208. Ver aqui esclarecedora explicação a respeito dos 'trabalhadores jurídicos'.

${ }^{258}$ E. R. GRAU, Ensaio e discurso..., op. cit., pp. 66-67. Aqui, vide a discussão, levantada por Eros Grau, referente à interpretação promovida pelos demais operadores do direito.

${ }^{259}$ F. MÜLLER, Direito, linguagem, violência..., op. cit., p. 212.

${ }^{260}$ F. MÜLLER, Direito, linguagem, violência..., op. cit., p. 213.
} 
esquema epistemológico abstrato, sugere que palavras e expressões presentes nos textos normativos não têm um significado 'em si', que possam ser extraídos por meio da interpretação, mas têm o seu significado construído a partir de seus usos, dentro do jogo de linguagem que está em funcionamento, conforme concepção estabelecida na segunda fase da filosofia de Wittgenstein. Por exemplo, palavras e expressões como 'residência' e 'invadir', no direito penal, e 'aptidão' e 'grave violação de obrigação matrimonial', no direito de família, tem o seu significado conforme o seu uso dentro do jogo de linguagem que está em funcionamento nesses campos do direito. ${ }^{261}$

Cara à concepção hermenêutica de Müller é a tese da inseparabilidade da interpretação e da aplicação, a qual está apoiada no ponto de vista central do referencial teórico da Hermenêutica Filosófica: a compreensão como processo atual, ou, por outras palavras, o reconhecimento de sentido e a aplicação inseparáveis num processo unitário, que inclui necessariamente o sujeito compreendente e concretiza e leva a termo em primeira instância esse sentido a ser entendido, não obstante a simultânea vinculação integral ao sentido do texto. ${ }^{262}$

Outra questão cara à hermenêutica mülleriana diz respeito a uma original noção de normatividade, a qual vem a corresponder a uma específica estrutura normativa, ou, em outras palavras, a uma estrutura interna específica do trabalho jurídico. Os elementos dessa estrutura específica do trabalho jurídico, ou melhor, da estrutura da norma jurídica, se revelam em máxima concreção no 'programa da norma' e no 'âmbito da norma' ${ }^{263}$

O 'programa da norma' é a composição do teor literal da norma jurídica, o texto de lei, com todos os recursos interpretativos auxiliares considerados em conjunto e determinando uns aos outros. $\mathrm{O}$ 'âmbito da norma', pertencente à norma como mesmo grau hierárquico do 'programa da norma', “é a estrutura básica do segmento da realidade social”, selecionada por meio do 'programa da norma' como a sua área de regulamentação ou, mesmo, criada em parte pelo 'programa da norma'264.

Grosso modo, o processo de concreção normativa tem início com o manuseio do texto normativo e, mediante a aplicação de procedimentos cognitivos sobre o conjunto de tais textos, por meio de recursos interpretativos, tanto aqueles ligados aos cânones hermenêuticos como quaisquer outros reconhecidos amplamente, obtém-se o 'programa da

\footnotetext{
${ }^{261}$ F. MÜLLER, Direito, linguagem, violência..., op. cit., p. 219.

${ }^{262}$ F. MÜLLER, Strukturierende Rechtslehre..., op. cit., p. 55.

${ }^{263}$ F. MÜLLER, Direito, linguagem, violência..., op. cit., pp. 223-224.

${ }^{264}$ F. MÜLLER, Direito, linguagem, violência..., op. cit., p. 224.
} 
norma'. Por meio dele, e tendo em consideração a situação específica do caso em estudo, elabora-se o 'âmbito da norma', que é a estrutura básica do segmento da realidade regulada e obtida pelo 'programa da norma'. Contudo, deve-se ter em mente que o 'âmbito da norma' não se identifica com os elementos factuais particulares das circunstâncias da espécie. Pelo contrário, o 'âmbito da norma' faz parte da própria estrutura da prescrição jurídica. ${ }^{265}$

A relevante conclusão ao se apresentar a concreção normativa é a de que todos os processos e elementos por ela utilizados, não têm caráter normativo uma vez que constituem apenas dados de entrada. O caráter normativo, a normatividade, somente nascerá quando, no processo de concreção normativa, forem obtidos os seus elementos finais: a norma jurídica e a norma-decisão, o que vale a dizer, de outro modo, que somente elas possuem normatividade. Os textos normativos não possuem, portanto, normatividade, embora possuam validade, o que, nada obstante, confere a eles a necessidade de serem observados e respeitados. $^{266}$

Ao analisarmos mais detidamente a Metódica Estruturante concluímos que a sua concreção normativa se processa por fases em que ocorre a interação entre um elemento de concreção que decorre dos fatos, como o Sachverhalt, e outro que decorre dos dados primariamente linguísticos originados dos textos de norma e do trabalho jurídico que sobre eles é realizado, como é exemplo o Normtextmenge, de tal maneira que sempre um deles sofrerá uma seleção, um corte, em face do outro, se transformando num terceiro elemento de concreção, de menor complexidade, mais próximo da norma jurídica a ser obtida no final e, portanto, mais impregnado tanto de dados linguísticos quanto de dados reais.

Esse processo de seleção se dá progressivamente, como que numa dialética espiral convergente para, selecionando e excluindo hipóteses, reduzir a complexidade inicial do universo de elementos envolvidos no caso até a solução relevante, precisa, coerente, consubstanciada no binômio norma jurídica/norma decisão.

Concluímos, então, que a Metódica Estruturante corresponde à construção de uma estrutura dinâmica, que se opera por um processo de seleção de elementos correlatos, escolhendo aqueles que são relevantes com base em elementos obtidos na etapa antecedente desse processo, ora de ordem fática, ora de ordem texto-normativa. Essa estrutura dinâmica tem como ponto de equilíbrio aquele correspondente ao par de coordenadas [programa da norma, área da norma]. A identidade da Metódica é, assim, definida pelo rol de elementos de

\footnotetext{
${ }^{265}$ J. M. A. DE ANDRADE, Interpretação..., op. cit., p. 154.

${ }^{266}$ J. M. A. DE ANDRADE, Interpretação..., op. cit., p. 156.
} 
concreção ao lado dessa estrutura dinâmica.

Construído esse referencial teórico, parâmetro de estruturação argumentativa de decisões, no âmbito da jurisprudência do STF, no campo da ordem econômica, prosseguimos com o capítulo final em que aplicamos a metódica, analisando os argumentos apresentados no julgamento de ações diretas ou recursos extraordinários, que se deram dentro da temática de 7 (sete) casos escolhidos: dos Correios, das tablitas, das mensalidades escolares, da meia entrada, das farmácias, da destilaria Alto Alegre e do Apagão; correspondendo a um total de 22 (vinte e dois) votos analisados.

Podemos sintetizar os resultados na seguinte tabela:

Tabela IV: Síntese de resultados

\begin{tabular}{|c|c|c|c|}
\hline Casos & Votos & $\begin{array}{l}\text { Elementos de } \\
\text { Concreção }\end{array}$ & $\begin{array}{l}\text { Estrutura } \\
\text { dinâmica }\end{array}$ \\
\hline \multirow{2}{*}{ Correios } & Marco Aurélio & $\sqrt{ }$ & Fraca \\
\hline & Eros Grau & $\sqrt{ }$ & - \\
\hline \multirow{5}{*}{ Tablitas } & Ilmar Galvão & $\sqrt{ }$ & - \\
\hline & Celso de Mello & $\sqrt{ }$ & Fraca \\
\hline & Maurício Corrêa & $\sqrt{ }$ & - \\
\hline & Nelson Jobim & $\sqrt{ }$ & - \\
\hline & Marco Aurélio & $\sqrt{ }$ & - \\
\hline \multirow{3}{*}{ Meia entrada } & Eros Grau & $\sqrt{ }$ & - \\
\hline & Marco Aurélio & $\sqrt{ }$ & - \\
\hline & Carlos Britto & $\sqrt{ }$ & - \\
\hline \multirow{6}{*}{$\begin{array}{l}\text { Mensalidades } \\
\text { Escolares }\end{array}$} & Moreira Alves & $\sqrt{ }$ & - \\
\hline & Marco Aurélio & $\sqrt{ }$ & - \\
\hline & Celso de Mello & $\sqrt{ }$ & - \\
\hline & Paulo Brossard & $\sqrt{ }$ & - \\
\hline & Eros Grau & $\sqrt{ }$ & - \\
\hline & Joaquim Barbosa & $\sqrt{ }$ & - \\
\hline \multirow{2}{*}{ Farmácias } & Marco Aurélio & $\sqrt{ }$ & - \\
\hline & Maurício Corrêa & $\sqrt{ }$ & - \\
\hline \multirow{2}{*}{$\begin{array}{l}\text { Destilaria Alto } \\
\text { Alegre }\end{array}$} & Carlos Velloso & $\sqrt{ }$ & - \\
\hline & Joaquim Barbosa & $\sqrt{ }$ & - \\
\hline \multirow{2}{*}{ Apagão } & Néri da Silveira & $\sqrt{ }$ & - \\
\hline & Nelson Jobim & $\sqrt{ }$ & - \\
\hline
\end{tabular}

Traduz a tabela anterior exatamente a constatação de que, embora se possam reconhecer, quer em maior, quer em menor número, elementos de concreção em todos os votos analisados, não se reconhece neles a estrutura dinâmica que é característica da Metódica Estruturante, portanto, o seu particular modo de erigir o processo de concreção normativo.

As exceções a essa constatação geral, que não se constituem em grande objeção à 
regra, porque fracamente observadas, são os votos proferidos pelos Ministros Marco Aurélio, no caso dos Correios, e pelo Ministro Celso de Mello, no caso das tablitas, cuja organização aproxima-se, embora em fraca medida, da estrutura constitutiva da metódica, por apresentarem algum grau de seleção de elementos relevantes com base em elementos obtidos em etapas anteriores, considerando em sua argumentação fatos relevantes do contexto fático ou dados primariamente linguísticos, provenientes dos textos normativos.

De fato, no caso das tablitas, por exemplo, verificou-se que o voto proferido pelo Ministro Celso de Mello foi aquele que guardou maior conformidade em relação à estrutura proposta pela metódica tomada como modelo. Assim, além de terem sido identificados nesse voto diversos elementos de concreção, também foi possível reconhecer o encadeamento da argumentação no sentido de selecionar elementos correlatos, ora do conjunto de textos de norma, ora do conjunto de fatos.

Necessário que se diga, nos demais votos, com maior ou menor incidência, foram verificados alguns dos elementos de concreção, porém em nenhum deles houve a correspondência entre a sua estrutura argumentativa e a estrutura construída pela metódica estruturante, a qual erige a tese de que a concreção se dá por meio da interação sucessiva de elementos fáticos e narrativos num processo de seleção e de redução de complexidade.

Vale ressaltar, novamente, que o voto proferido pelo Ministro Nelson Jobim se torna emblemático, no sentido da inconformidade com a metódica, ao adotar uma organização que progride em função da construção de argumentos autônomos que, ao final, concorrem para a solução do caso, afastando-se de uma estrutura como aquela do modelo mülleriano.

Assim, em relação à quase totalidade dos votos analisados, embora se possam identificar, ainda que precariamente, elementos de concreção da metódica estruturante, verifica-se um importante distanciamento entre o modelo erigido por essa metódica e a organização seguida em tais votos.

De fato, verifica-se que os votos organizam-se mais em torno da construção progressiva de argumentos orientados para a solução do caso, não se verificando qualquer processo seletivo como aquele que ocorreria a partir do 'relato do caso' (Fallerzählung), obtendo o 'conjunto de matérias' (Sachverhalt), que, por sua vez, também por um processo seletivo, deriva o 'âmbito da matéria' (Sachbereich), e, assim por diante, até a obtenção do 'programa da norma' (Normprogramm), elemento de menor complexidade nessa espiral.

Como conclusão, podemos afirmar que, para o grupo de decisões analisadas no 
campo do substrato escolhido, a ordem econômica, proferidas pela Corte constitucional pátria, embora se possam reconhecer elementos de concreção em tais votos, não é possível identificar neles o processo dinâmico, nuclear, da metódica estruturante, elemento essencial de sua identidade. Por outro lado, revela-se nos votos, com maior ou menor evidência, uma organização em torno de argumentos autônomos que concorrem para a formação do enunciado conclusivo, orientado no sentido da solução do caso.

Ante todo o exposto, em relação à amostra estudada, verifica-se que não há correspondência entre a estrutura argumentativa da jurisprudência do Supremo Tribunal Federal e um padrão de organização estruturado como aquele erigido pela Metódica Estruturante de Friedrich Müller. 


\section{BIBLIOGRAFIA}

ABBAGNANO, Nicola, História da filosofia, v.11, 4. ed., Lisboa, Editorial Presença, 2000

ADEODATO, João Maurício, Ética e Retórica - para uma teoria da dogmática jurídica, São Paulo, Saraiva, 2002.

AGUILAR, Fernando Herren, Direito Econômico - Do Direito Nacional ao Direito Supranacional, São Paulo, Atlas, 2006.

ALVES, Alaôr Caffé, Lógica - Pensamento Formal e Argumentação, Elementos para o Discurso Jurídico, 3.ed., São Paulo, Quartier Latin, 2003.

ANDRADE, José Maria Arruda de, Hermenêutica Constitucional e Teoria Estruturante do Direito, Artigo publicado na Revista Brasileira de Estudos Constitucionais (RBEC), v. 7. São Paulo, Editora Fórum, 2008.

ANDRADE, José Maria Arruda de, Interpretação da Norma Tributária, São Paulo, MP Editora, 2006.

BERCOVICI, Gilberto, Constituição Econômica e Desenvolvimento - Uma Leitura a Partir da Constituição de 1988, São Paulo, Malheiros Editores, 2005.

BERCOVICI, Gilberto, Os Princípios Estruturantes e o Papel do Estado, in A Constituição Brasileira de 1988 Revisitada: Recuperação Histórica e Desafios Atuais das Políticas Públicas nas Áreas Econômica e Social, v.1, Org. José Celso Cardoso Jr., Brasília, IPEA, 2009.

BILlIER, Jean-Cassien; MARYIOLI, Aglaé, Histoire de la Philosophie du Droit, 2001, trad. port. de M. de Andrade, História da Filosofia do Direito, Barueri-SP, Manole, 2005.

BITTAR, Eduardo C. B., Linguagem Jurídica, 4.ed., São Paulo, Saraiva, 2009. 
BITTAR, Eduardo C. B.; ALMEIDA, Guilherme Assis de, Curso de Filosofia do Direito, 7.ed., São Paulo, Atlas, 2009.

BOBBIO, Norberto, O Positivismo Jurídico - lições de filosofia do direito, trad. port. de M. Pugliese, E. Bini, C. E. Rodrigues, São Paulo, Ícone, 2006.

BONAVIDES, Paulo, Curso de Direito Constitucional, 24. ed., São Paulo, Malheiros, 2009.

CANARIS, Claus-Wilhelm, Systemdenken und Systembegriff in der Jurisprudenz, 1983, trad. port. de A. M. Cordeiro, Pensamento Sistemático e Conceito de Sistema na Ciência do Direito, Lisboa, Calouste Gulbenkian, 2008.

CANOTILHO, JJ Gomes, Direito Constitucional e Teoria da Constituição, 7. ed., Coimbra, Almedina, 2008.

CHRISTENSEN, Ralph, Teoria Estruturante do Direito, trad. port. de R. M. dos Santos, in O Novo Paradigma do Direito - Introdução à teoria e metódica estruturantes do direito, São Paulo, Revista dos Tribunais, 2007.

COMPARATO, Fábio Konder, O indispensável direito econômico, in Ensaios e pareceres de direito empresarial, Rio de Janeiro, Forense, 1978.

DIMOULIS, Dimitri, Positivismo Jurídico - Introdução a uma teoria do direito e defesa do pragmatismo jurídico-político, São Paulo, Método, 2006.

ENGISCH, Karl, Einführung in das Juristische Denken, 1983, trad. port. de J. B. Machado, Introdução ao Pensamento Jurídico, 10.ed., Lisboa, Calouste Gulbenkian, 2008.

FERRAZ JR., Tércio Sampaio, Introdução ao Estudo do Direito - Técnica, Decisão, Dominação, 4.ed., São Paulo, Atlas, 2003. 
FREITAS, Juarez, O Intérprete e o Poder de dar Vida à Constituição - Preceitos de Exegese Constitucional, in Direito Constitucional - Estudos em homenagem a Paulo Bonavides, São Paulo, Malheiros, 2003, pp. 226-248.

GADAMER, Hans-Georg, Warheit und methode, trad. port. de F. P. Meurer, Verdade e Método I - Traços fundamentais de uma hermenêutica filosófica, 8.ed., Petrópolis, Vozes; Bragança Paulista, Editora Universitária São Francisco, 2007.

GLOCK, Hans-Johan, Dicionário Wittgenstein, trad. port. de H. Martins, Rio de Janeiro, Jorge Zahar Editor, 1998.

GRAU, Eros Roberto, A Ordem Econômica na Constituição de 1988, 12.ed., São Paulo, Malheiros Editores, 2007.

GRAU, Eros Roberto, Constituição e Serviço Público, in Direito Constitucional - Estudos em homenagem a Paulo Bonavides, São Paulo, Malheiros, 2003, pp. 249-267.

GRAU, Eros Roberto, Ensaio e discurso sobre a interpretação/aplicação do direito, 4.ed., São Paulo, Malheiros Editores, 2006.

GRAU, Eros Roberto, $O$ Direito Posto e o Direito Pressuposto, 7.ed., São Paulo, Malheiros Editores, 2008.

HACKER, P. M. S., Wittgenstein - On Human Nature, 1997, trad. port. de J. V. Gallenari Cuter, Wittgenstein - sobre a natureza humana, São Paulo, UNESP, 2000.

HART, Herbert L. A, The Concept of Law, 1994, trad. port. de A. R. Mendes, O Conceito de Direito, 5.ed., Lisboa, Calouste Gulbenkian, 2007.

HESSE, Konrad, Grundzüge des Verfassungsrechts der Bundesrepublik Deutschland, 20.ed., trad. port. de L. A Heck, Elementos de Direito Constitucional da República Federal da Alemanha, Porto Alegre, Sergio Antonio Fabris Editor, 1998. 
JOUANJAN, Olivier, De Hans Kelsen a Friedrich Müller - Método jurídico sob o paradigma pós-positivista, trad. port. de R. I. Jansen dos Santos, in O Novo Paradigma do Direito - Introdução à teoria e metódica estruturantes do direito, São Paulo, Revista dos Tribunais, 2007.

KELSEN, Hans, Reine Rechtslehre, 1960, trad. port. de J. B. Machado, Teoria Pura do Direito, 6.ed., São Paulo, Martins Fontes, 1998.

LARENZ, Karl. Metodologia da Ciência do Direito. 3.ed., Lisboa, Fundação Calouste Gulbenkian, 1997.

MAXIMILIANO, Carlos, Hermenêutica e Aplicação do Direito, 19.ed., Rio de Janeiro, Forense, 2006.

MONCADA, Luís S. Cabral de, Direito Económico, 5.ed., Coimbra, Coimbra Editora, 2007.

MÜLLER, Friedrich, Direito, linguagem, violência, trad. port. de P. Naumann, in O Novo Paradigma do Direito - Introdução à teoria e metódica estruturantes do direito, São Paulo, Revista dos Tribunais, 2007.

MÜLlER, Friedrich, O Novo Paradigma do Direito - Introdução à teoria e metódica estruturantes do direito, trad. port. de P. Naumann, São Paulo, Revista dos Tribunais, 2007.

MÜLLER, Friedrich, Strukturierende Rechtslehre, trad. port. de P. Naumann e E. A. de Souza, Teoria Estruturante do Direito, São Paulo, Revista dos Tribunais, 2008.

MÜLLER, Friedrich, Teoria Estruturante da Norma Jurídica e do Direito, trad. port. de R. I. Jansen dos Santos, in O Novo Paradigma do Direito - Introdução à teoria e metódica estruturantes do direito, São Paulo, Revista dos Tribunais, 2007.

NEVES, Antonio Castanheira, A Crise Actual da Filosofia do Direito no Contexto da 
Crise Global da Filosofia - Tópicos para a possibilidade de uma reflexiva reabilitação, Coimbra, Editora Coimbra, 2003.

NEVES, Antonio Castanheira, Digesta, v.2, Coimbra, Editora Coimbra, 1995.

NEVES, Antônio Castanheira, Metodologia Jurídica - problemas fundamentais, Coimbra, Editora Coimbra, 1993.

NEVES, Marcelo, A Constitucionalização Simbólica, São Paulo, WMF Martins Fontes, 2007.

NEVES, Marcelo, A Interpretação Jurídica no Estado Democrático de Direito, in Direito Constitucional - Estudos em homenagem a Paulo Bonavides, São Paulo, Malheiros, 2003, pp. 356-376.

NUNES, Antônio José Avelãs, Uma Introdução à Economia Política, São Paulo, Quartier Latin, 2007.

NUSDEO, Fábio, Curso de Economia - Introdução ao Direito Econômico, 5.ed., São Paulo. Editora Revista dos Tribunais, 2008.

ROESLER, Claudia Rosane, Theodor Viehweg e a Ciência do Direito - Tópica, Discurso, Racionalidade, Florianópolis, Momento Atual, 2004.

RORTY, Richard, Pragmatismo e Política, trad. port. de P. Ghiraldelli Jr., São Paulo, Martins, 2005.

ROSS, Alf, On Law and Justice, trad. port. de E. Bini, Direito e Justiça, Bauru-SP, EDIPRO, 2003.

STERN, Klaus, O Juiz e a Aplicação do Direito, in Direito Constitucional - Estudos em homenagem a Paulo Bonavides, São Paulo, Malheiros, 2003, pp.505-515. 
TEIXEIRA, António Braz, Sentido e Valor do Direito - Introdução à filosofia jurídica, 2.ed., Lisboa, Imprensa Nacional - Casa da Moeda, 2000.

VIEHWEG, Theodor, Topik und Jurisprudenz - Ein Beitrag zur rechtswissenschaftlichen Grundlagenforschung, 5.ed., trad. port. de K. S. A. da Silva, Tópica e Jurisprudência Uma contribuição à investigação dos fundamentos jurídico-científicos, Porto Alegre, Sergio Antonio Fabris Editor, 2008.

VILANOVA, Lourival, Estruturas Lógicas e o Sistema de Direito Positivo, 3.ed., São Paulo, Noeses, 2005.

WIEACKER, Franz, Privatrechtsgeschichte der Neuzeit unter Besonderer Berücksichtigung der Deutschen Entwicklung, 1967, trad. port. de A. M. B. Hespanha, História do direito privado moderno, 2. ed., Lisboa, Calouste Gulbenkian, 1993.

WITTGENSTEIN, Ludwig, Philosophische Untersuchungen, 1958, trad. port. de M. G. Montagnoli, Investigações Filosóficas, 5.ed., Bragança Paulista, Editora Universitária São Francisco - Petrópolis, Vozes, 2008.

WITTGENSTEIN, Ludwig, Tractatus Logico-Philosophicus, 1961, trad. port. de L. H. Lopes dos Santos, 3.ed., 1. reimp., São Paulo, EDUSP, 2008.

WITTGENSTEIN, Ludwig, Über Gewissheit, 1969, trad. port. de M. E. Costa, Da certeza, Lisboa, Edições 70, 1998.

SUPREMO TRIBUNAL FEDERAL, Informativo STF nº 392-1, de 13 a 17 de junho de 2005, disponível [on-line] in http://www.stf.jus.br//arquivo/informativo/documento/informativo392.htm [13-09-2009].

SUPREMO TRIBUNAL FEDERAL, Informativo STF $\mathrm{n}^{\circ}$ 392-2, de 13 a 17 de junho de 2005, disponível [on-line] in http://www.stf.jus.br//arquivo/informativo/documento/informativo392.htm [13-092009].

SUPREMO TRIBUNAL FEDERAL, Informativo STF $\mathrm{n}^{\circ} 409$, de 14 a 18 de novembro de $2005, \mathrm{n}^{\circ} 510$, de 9 a 13 de junho de 2008 e $\mathrm{n}^{\circ} 554-1$ e $^{\circ}$ 554-2, de 3 a 7 de agosto de 2009; disponíveis [on-line] in http://www.stf.jus.br//arquivo/informativo/documento/informativo409.htm ou /informativo510.htm ou 
linformativo554.htm [13-09-2009].

SUPREMO TRIBUNAL FEDERAL, Arguição de Descumprimento de Preceito Fundamental, ADPF 46-7/DF, Relator Ministro Marco Aurélio, disponível [on-line] in http://redir.stf.jus.br/paginadorpub/paginador.jsp? docTP $=A C \&$ docID $=60850 /[15-01-2013]$.

SUPREMO TRIBUNAL FEDERAL, Recurso Extraordinário, RE 164.836-8/MG, Relator Ministro Marco Aurélio, Relator Min. Marco Aurélio, disponível [on-line] in http://redir.stf.jus.br/paginadorpub/paginador.jsp?docTP $=A C \& d o c I D=215423 /$ 2013].

SUPREMO TRIBUNAL FEDERAL, Recurso Extraordinário, RE 141.190-2, Relator Ministro Ilmar Galvão, disponível [on-line] in http://redir.stf.jus.br/paginadorpub/paginador.jsp? $\underline{\operatorname{docTP}=A C \& d o c I D=208681 /}[$ [15-01-2013].

SUPREMO TRIBUNAL FEDERAL, Ação Direta de Inconstitucionalidade, ADI 3512-6/ES, Relator Ministro Eros Grau, disponível [on-line] in http://redir.stf.jus.br/paginadorpub/paginador.jsp? docTP $=A C \&$ docID $=363387,[15 / 01 / 2013]$.

SUPREMO TRIBUNAL FEDERAL, Ação Direta de Inconstitucionalidade, ADI 1950-3/SP, Relator Ministro Eros Grau, disponível [on-line] in http://redir.stf.jus.br/paginadorpub/paginador.jsp?docTP=AC\&docID=266808, [15-01-2013].

SUPREMO TRIBUNAL FEDERAL, Ação Direta de Inconstitucionalidade, ADI 319-4/DF, Relator Ministro Moreira Alves, disponível [on-line] in http://redir.stf.jus.br/paginadorpub/paginador.jsp?docTP=AC\&docID=918, [15-01-2013].

SUPREMO TRIBUNAL FEDERAL, Ação Direta de Inconstitucionalidade, ADI 1.007-7/PE, Relator Ministro Eros Grau, disponível [on-line] in http://redir.stf.jus.br/paginadorpub/paginador.jsp?docTP=AC\&docID=266615, [15-012013].

SUPREMO TRIBUNAL FEDERAL, Recurso Extraordinário, RE 189.170-0/SP, Relator 
Ministro

Marco

Aurélio,

disponível

[on-line]

in

http://redir.stf.jus.br/paginadorpub/paginador.jsp?docTP $=A C \& d o c I D=230851$, 2013].

SUPREMO TRIBUNAL FEDERAL, Recurso Extraordinário, RE 422.941-2/DF, Relator

Ministro Carlos Velloso, disponível in

http://redir.stf.jus.br/paginadorpub/paginador.jsp?docTP=AC\&docID=368446, $\quad$ [15-012013].

SUPREMO TRIBUNAL FEDERAL, Ação Declaratória de Constitucionalidade, ADECON 96/DF, Relator Ministro Néri da Silveira, disponível [on-line] in http://redir.stf.jus.br/paginadorpub/paginador.jsp? docTP $=A C \& d o c I D=883$, [15-01-2013]. 